Беш Л.В., Ласиця Т.С., Беш О.М.

\title{
Бронхіальна астма в практиці сімейного лікаря
}

У книзі викладені проблемні питання бронхіальної астми. Наведено дані щодо ii етіології та патогенезу, особливостей клінічних проявів, критеріїв діагностики, вікової еволюції, лікування і профілактики.

\section{Рецензенти :}

член-кореспондент НАМН України, д.м.н., професор Перцева Т.О.

д.м.н., професор Кривопустов С.П.

Редактор : к.м.н., доцент Головко I.М.

Затверджено на засіданні центральної методичної комісії Львівського національного медичного університету імені Данила Галицького. Протокол № 4 від 07 грудня 2017 року. Рекомендовано як навчальний посібник для студентів вищих навчальних закладів IV рівня акредитації, лікарів-інтернів, алергологів, пульмонологів, лікарів загальної практики - сімейної медицини. 


\section{Відомості про авторів:}

Беш Леся Василівна - д.м.н., професор, завідувач кафедри педіатрії №2 Львівського національного медичного університету імені Данила Галицького, керівник Львівського міського дитячого алергологічного центру.

Ласиця Тетяна Станіславівна - к.м.н., старший науковий співробітник наукового відділу внутрішньої медицини, завідувач навчального центру «Інститут післядипломної освіти» Державної наукової установи «Науковопрактичний центр клінічної та профілактичної медицини» Державного управління справами.

Беш Олеся Михайлівна - к.м.н., асистент кафедри внутрішньої медицини №2 Львівського національного медичного університету імені Данила Галицького. 


\section{Bid aвmopis}

Видання короткого посібника «Бронхіальна астма в практицуі сімейного лікаря» $\epsilon$ певною мірою доповненням до першої книги під такою ж назвою, написаної багато років тому головним дитячим алергологом України професором О.І.Ласицею та ї̈ донькою - відомим терапевтом Т.С. Ласицею. У 2006 роизі Ольга Іларіонівна Ласиия пішла з життя. Вона залишила по собі науковий доробок, школу, спогади, а також прищеплені всім нам допитливість $i$ відчуття сучасності. Для нас робота над книгою була, перш за все продиктована вдячністю вчителю. Посібник містить в собі не лише останні рекомендації щуодо діагностики, лікування, вікової еволющії та менеджменту бронхіальної астми на підставі доказової медицини, але й власний досвід авторів. Ми намагалися представити не стільки базові знання, скільки тактику сучасного ведення хворих з акиентом на індивідуальний підхід $i$ підвищення прихильності пацієнтів до лікування.

Посібник є розмовою з мудрим лікарем і запрошує до діалогу. 


\section{MICT}

- Визначення та епідеміологія бронхіальної астми

- Класифікація бронхіальної астми

- Особливості етіології, патогенезу та характеристика запалення при бронхіальній астмі

- Клініка бронхіальної астми

- Функціональне дослідження легень і методи діагностики запалення дихальних шляхів при бронхіальній астмі

- Специфічна алергодіагностика

- Вікова еволюція бронхіальної астми : від дитини до дорослого

- Перебіг бронхіальної астми під час вагітності та її вплив на плід

- Бронхіальна астма у дорослих і коморбідні стани

- Лікування бронхіальної астми

- Алерген-специфічна імунотерапія бронхіальної астми

- Трудна астма у дітей : особливості трактування і терапії

- Історичний екскурс - GINA 1995-2017 роки

- Прихильність до лікування та навчання пацієнтів

- Бронхіальна астма: аналіз діагностичних і тактичних помилок

- Лiтература

- Додатки 


\section{ВИЗНАЧЕННЯ ТА ЕПІДЕМІОЛОГІЯ БРОНХІАЛЬНОЇ АСТМИ}

Проведені протягом останніх років епідеміологічні дослідження в Свропі та інших регіонах світу показують, що відбувається постійне і досить стрімке прогресування поширеності алергічних захворювань. Близько третини населення земної кулі страждають на алергічні захворювання, зокрема на бронхіальну астму хворіє близько 334 млн людей, що складає приблизно 5\% жителів, поширеність серед дітей і молодих дорослих ще вища (14,0 і 8,6\% відповідно) (The Global Asthma Report 2014).

Бронхіальна астма (БА) - це самостійне хронічне захворювання, обов'язковим патогенетичним механізмом якого $є$ хронічний запальний процес $\mathrm{i}$ пов'язана 3 ним гіперреактивність бронхів, зумовлені специфічними імунологічними (сенсибілізація та алергія) чи неспецифічними механізмами, а основними клінічними проявами є свистяче дихання, ядуха, відчуття стискання у грудях і кашель. Ці клінічні симптоми зазвичай пов'язані з поширеною, але варіабельною бронхообструкцією, яка є зворотною спонтанно або під впливом терапії.

Бронхіальна астма і сьогодні асоційована 3 ризиком інвалідизації та смертності. Згідно даних ВООЗ, серед 15 мільйонів пацієнтів, що $є$ інвалідами, $1 \%$ складають хворі на бронхіальну астму. Значне погіршення якості життя хворих, зниження їх суспільної активності, великий відсоток інвалідизації та можливість смертельного результату викликають стурбованість не тільки лікарів, а й суспільства в цілому. Фінансові витрати внаслідок бронхіальної астми призводять до значних соціально-економічних проблем. Зокрема, у США щорічні витрати, пов'язані з бронхіальною астмою, складають близько 60 млрд доларів. З урахуванням поширеності, впливу на якість життя, частоти інвалідності та фінансових витрат, бронхіальна астма сьогодні займає 14-те місце у рейтингу найбільш актуальних захворювань у світі.

Дана патологія не тільки впливає на психічні, фізичні та соціальні аспекти життя хворого, але й морально і фінансово виснажує всіх членів його сім'ї. Саме тому своєчасне виявлення бронхіальної астми сприяє не лише зниженню інвалідизації і підвищенню ефективності лікування, але й уникненню додаткових фінансових витрат сім'ї. Зважаючи на труднощі в отриманні якісних епідеміологічних даних, показники вітчизняної офіційної медичної статистики $є$ суттєво нижчими за світові. Перш за все така ситуація пояснюється неможливістю провести якісні епідеміологічні дослідження i отримати статистичні дані на підставі звертань за медичною допомогою, а не на підставі активного виявлення патології. Водночас правильно організовані епідеміологічні дослідження дозволяють вивчити формування захворювання 
шляхом дослідження поширеності, аналізу розподілу по території, а також еволюції бронхіальної астми в залежності від віку, часу, форми і важкості, виявити фактори, що сприяють прогресуванню патологічного процесу та інвалідизації, оцінити ефективність профілактичних заходів.

Дослідження поширеності є ключовим в епідеміологічній програмі, для чого використовуються різні методики, в основі яких лежить опитування різних груп населення, дані медичної статистики, а також дослідження об'єктивних маркерів захворювання. Вивчення поширеності на підставі звернень за медичною допомогою не відображає справжньої ситуації. Цілеспрямовані клініко-епідеміологічні дослідження в кілька разів перевищують показники офіційної статистики. Мають значення також і відмінності у визначенні захворювання як нозологічної форми, відповідність сучасній класифікації, недостатнє використання стандартизованих функціональних методів обстеження бронхіальної обструкції, недостатня доступність і висока вартість визначення таких об'єктивних маркерів атопії, як рівень загального i специфічного сироваткового IgE.

Методика епідеміологічного дослідження має важливе значення, що суттєво позначається на результатах та їх порівнянні з даними інших авторів у просторовому та часовому відношенні. Найбільш інформативними та достовірними $є$ уніфіковані методики, що відповідають вимогам повного епідемічного дослідження 3 використанням стандартних, добре розроблених анкет.

У 1985 році була розроблена методика ISAAC ( International Study of Asthma and Allergies in Childhood), яка дозволила не лише провести широкомасштабні дослідження та їх порівняльний аналіз між різними регіонами і країнами, але й організувати вивчення динаміки показників у часовому аспекті. Дослідження, проведені за цією методикою й опубліковані в матеріалах конгресу Європейської Асоціації алергологів та клінічних імунологів, свідчать про велику поширеність бронхіальної астми серед дітей. Цифри коливаються від 5 до 22\%. Найбільша поширеність реєструється в Ірландії (15,7\%), Швейцарії (17,5\%), Сінгапурі (22\%) й Австралії (19\%). Для вивчення поширення алергічних захворювань у дорослих використовується опитувальник "European Community Respiratory Health Survey".

Існують значні відмінності епідеміологічних показників щодо бронхіальної астми в залежності від фактору географічного розташування та урбанізації. Доведено, що діти в урбанізованих регіонах хворіють на астму частіше. Встановлені гендерні відмінності, які показують, що хлопчики хворіють у два рази частіше, ніж дівчатка, однак до досягнення підліткового віку ця різниця стирається.

Актуальність проблеми бронхіальної астми зумовлена не лише iї поширеністю. На щастя, сьогодні смертність від цієї недуги вже не є такою 
високою, як кілька десятиліть тому. Але, як і раніше, бронхіальна астма продовжує бути частою причиною втрати працездатності, пропуску шкільних занять і значним економічним тягарем. В Україні, на жаль, оцінити реальну поширеність бронхіальної астми і динаміку цього показника на сьогодні дуже важко, оскільки масштабні епідеміологічні дослідження 3 вивчення поширеності даного захворювання в нашій країні не проводилися вже багато років. За даними офіційної статистики на 2015 рік, частота бронхіальної астми серед дорослого і дитячого населення склала близько $0,5 \%$. Такі показники щонайменше в 10 разів нижчі, ніж у середньому в світі, що може свідчити про відсутність коректного діагнозу у великої кількості пацієнтів.

Бронхіальна астма $\epsilon$ найчастішою причиною розвитку інвалідності у дітей 3 хронічними неспецифічними захворюваннями легенів, а у дорослих поступається сумнівною першістю тільки хронічному обструктивному захворюванню легень. Приблизно десять відсотків хворих на бронхіальну астму в різних регіонах України стають інвалідами з дитинства. Ці діти потребують особливої уваги не тільки лікарів і медичних працівників, а й суспільства в цілому. 


\section{КЛАСИФІКАЦІЯ БРОНХІАЛЬНОЇ АСТМИ}

3 метою перегляду стандартів надання медичної допомоги дітям, хворим на алергічну патологію, в Україні працює група експертів, яка, аналізуючи міжнародні клінічні рекомендації і вітчизняний досвід, розробляє нові протоколи і клінічні настанови щодо діагностики і лікування бронхіальної астми. 08 жовтня 2013 Наказом МО3 України №868 затверджений уніфікований клінічний протокол первинної і вторинної (спеціалізованої) медичної допомоги при бронхіальній астмі.

Міжародними прототипами для оновлення національного протоколу були такі документи:

- $\quad$ Global Initiative for Asthma (GINA, 2006 - 2011);

- Global strategy for the diagnosis and management of asthma in children 5 years and younger, 2009;

- $\quad$ PRACTALL (Practical Allergology) Pediatric Asthma Group, 2008;

- $\quad$ ICON (International consensus on Pediatric Asthma), 2012.

На підставі адаптації міжнародних клінічних рекомендацій і вітчизняного досвіду робоча група експертів запропонувала нову класифікацію бронхіальної астми.

За етіологічним принципом бронхіальна астма класифікується як:

I. Алергічна (виникає під впливом неінфекційних алергенів; IgE- залежна та IgЕ-незалежна)

II. Неалергічна (неімунні форми астми - астма фізичного навантаження, аспіринова астма)

III. Змішана - виникає під впливом неінфекційних та інфекційних алергенів (в основі - імунні механізми)

За ступенем важкості перебігу захворювання (оцінюється при первинній діагностиці та перед початком лікування, а також у випадку, якщо пацієнт не отримував базисної терапії більше ніж місяць) астму поділяють на два варіанти: інтермітуюча (епізодична) і персистуюча (хронічна). Згідно цієї класифікації, інтермітуюча - легка астма (1 ст.), а важкість персистуючої бронхіальної астми (легка, середньої важкості, важка - 2-4 ст.) визначається частотою, вираженістю, тривалістю нападів, реакцією на терапію бронходилятаторами, станом хворого в міжприступному періоді (Додаток 1).

Таким чином, існують 4 ступені важкості бронхіальної асми. Не можна вважати такий розподіл бездоганним, проте заснована на визначенні ступеня важкості захворювання класифікація дозволяє вибрати найоптимальнішу тактику лікування.

Багаторічний досвід роботи показав, що є випадки, коли описана вище класифікація за важкістю перебігу $є$ не зовсім зручною для практичного 
застосування. Зокрема, нерідко виникає питання : Як трактувати астму у разі досягнення контролю над хворобою на фоні адекватної базисної терапії (симптомів хвороби немає, бо пацієнту підібране оптимальне лікування)? Тому науковці і практики постійно продовжують шукати компроміс. У 2006 році міжнародним узгоджувальним документом GINA запропонований поділ астми на контрольовану, частково контрольовану i неконтрольовану. За рівнем контролю бронхіальна астма оцінюється кожні три місяці лікування відповідно до ступеня терапії (Додаток 2). Для зручності практичної роботи лікаря GINA 2006 запропонувала тест контролю астми, який дозволяє швидко, лише на підставі даних анамнезу оцінити рівень контролю хвороби.

За перебігом захворювання бронхіальну астму розподіляють на:

- період загострення - прогресивне зростання ядухи, кашлю, свистячих хрипів, відчуття стискання в грудній клітці або будь-якої комбінації перерахованих симптомів;

- контроль - усунення проявів захворювання на фоні базисної терапії бронхіальної астми (контроль - це практично «медикаментозна ремісія» захворювання);

- період ремісії - повне усунення симптомів захворювання на тлі відміни базисної терапії.

Перебіг бронхіальної астми може призводити до розвитку ускладнень :

легеневе серце (гостре, підгостре. хронічне);

хронічна емфізема легень;

пневмосклероз;

сегментарний або полісегментарний ателектаз легень;

інтерстиціальна, медіастинальна або підшкірна емфізема;

спонтанний пневмоторакс;

неврологічні ускладнення (беталепсія - епізоди короткочасної втрати свідомості на висоті кашлю або нападу у разі важкої астми; судомний синдром, гіпоксична кома);

ендокринні розлади (затримка і відставання фізичного і статевого розвитку тощо).

Таким чином, згідно сучасної класифікації бронхіальної астми приклад діагнозу мав би виглядати так:

- Бронхіальна астма, алергічна, легкий персистуючий перебіг (II ст.), контрольована, ДН 0

Бронхіальна астма, змішана, важкий персистуючий перебіг (IVcт.), період загострення (важке загострення), ускладнена ателектазом середньої частки правої легені, ДН 1 


\section{ОСОБЛИВОСТІ ЕТІОПАТОГЕНЕЗУ ТА ХАРАКТЕРИСТИКА ЗАПАЛЕННЯ ПРИ БРОНХІАЛЬНІЙ АСТМІ}

Розглядаючи етіологію бронхіальної астми, виділяють 2 групи факторів ризику ії розвитку : фактори, які зумовлюють виникнення астми (перший епізод захворювання); фактори, що сприяють розвитку загострень астми (тригерні фактори).

1. Фактори, які зумовлюють виникнення астми (перший епізод захворювання):

-фактори схильності - генетична детермінованість (атопія, гіперреактивність бронхів);

- причинні фактори (алергени);

-сприятливі фактори (підвищують ризик виникнення хвороби на фоні впливу причинних факторів) - тютюновий дим, забруднення навколишнього середовища, респіраторні вірусні інфекції, шкідливі антенатальні фактори та перинатальна патологія.

2. Фактори, що сприяють розвитку загострень астми (тригерні фактори):

- контакт з алергеном*;

- фізичне навантаження*;

- вірусна інфекція;*

- холодне повітря;

- полютанти;

- тютюновий дим (активне та пасивне паління);

- метеофактори;

- психоемоційний стрес.

* - найбільш вагомі провокаційні фактори бронхіальної астми у дітей, що зумовлюють виокремлення іiі фенотипів: «вірус-індукований», «алергеніндукований», «індукований фізичним навантаженням».

Протягом останніх років опубліковано багато робіт, які доводять існування різних фенотипів астми. Сьогодні не має сумніву в тому, що виділення конкретних фенотипів i ендотипів астми $\epsilon$ дуже важливим у контексті вибору терапії і відповіді на лікування, однак наразі зарано впроваджувати такий розподіл у практичну медицину. Зокрема, на сьогодні залишається недосконалою діагностика різних запальних фенотипів бронхіальної астми. Після короткочасного оптимізму у цьому відношенні прийшло усвідомлення того факту, що варіант запалення бронхів, який визначається за цитологічним складом мокротиння, нерідко непостійний. На сучасному етапі бронхіальна астма розглядається як мультифакторне захворювання, при якому реалізація патологічного процесу визначається взаємодією генетичних факторів і чинників середовища. 
Сьогодні існують переконливі дані про те, що бронхіальна астма розвивається на підставі поліморфізму імунорегуляторних генів, які регулюють синтез IgE-антитіл та еозинофільне запалення, і водночас під дією факторів зовнішнього середовища. Власне взаємодія цих чинників ризику призводить до формування бронхіальної астми.

Сьогодні доведено, що до розвитку бронхіальної астми можуть бути дотичні понад 100 генів, зокрема відповідальні за вироблення алергенспецифічних IgE (атопія), прояви бронхіальної гіперреактивності, утворення медіаторів запалення, цитокінів, баланс між Th1/Th2-опосередкованими типами імунної відповіді. Протягом останніх років також вивчаються генетичні чинники у фармакотерапії астми, відповіді на протиастматичні засоби (гени, що кодують $\beta$-рецептори, регулюють відповідь на глюкокортикостероїди, антилейкотрієнові препарати тощо).

В осіб 3 атопічним генотипом спостерігається домінування Th2опосередкованої імунної відповіді, яка проявляється надмірною продукцією цитокінів (IL-4, IL-5, IL-9, IL-10, IL-13), що зумовлюють проліферацію і диференціювання В-клітин у клітини, які продукують антитіла (IgE). Протягом останніх років доведено, що, окрім Тh2-клітин, на різні аспекти запалення i бронхіальної гіперреактивності при бронхіальній астмі впливають, виділяючи специфічні цитокіни, i Th1- Th17-, Treg-, Th19-лімфоцити. Проникаючи в організм хворого, алерген взаємодіє з фіксованими на клітинах запалення (мастоцити або тканинні базофіли; базофіли й еозинофіли крові) IgEантитілами, внаслідок чого відбувається ушкодження фосфоліпідів клітинних мембран, поступлення йонів кальцію всередину клітини i вивільнення медіаторів: гістаміну, триптази, кінінів, лейкотрієнів В4 і C4, простагландину D2 тощо. Вплив медіаторів на ендотеліальні клітини судин і нейрорецептори слизової оболонки дихальних шляхів призводить до виникнення клінічних симптомів бронхіальної астми. Описані вище процеси становлять ранню фазу алергічної відповіді, а через 6-8 годин розвивається пізня фаза, яка не потребує повторного контакту 3 алергеном. Пізня фаза зумовлена еозинофілами i $\mathrm{T}$ лімфоцитами. Саме в цей період збільшується кількість еозинофілів у слизовій оболонці бронхів, відбувається їх активація 3 виділенням специфічних цитокінів, притягнення в зону алергічної реакції інших клітин, які, в свою чергу, також піддаються стимуляції i виділяють медіатори (лейкотрієни, простагландини, тромбоксан, фактор активації тромбоцитів) i токсичні протеїни, що призводить до розвитку хронічного запалення i формування специфічної та неспецифічної гіперреактивності дихальних шляхів. Таким чином, запальний процес, який розвивається у бронхах, є підгрунтям для розвитку бронхіальної гіперреактивності і симптомів бронхіальної астми.

Морфологічною основою звуження дихальних шляхів у разі бронхіальної астми є: бронхоспазм, набряк слизової оболонки бронхів, гіперсекреція слизу і 
утворення слизових корків, потовщення стінки бронхів унаслідок ремоделювання.

Морфологічні дослідження біопсій бронхів і рідини бронхоальвеолярного лаважу дозволили встановити особливості запалення дихальних шляхів при бронхіальній астмі. Характерним є збільшення числа ефекторних клітин та клітинна деструкція в слизовій оболонці бронхів, гіперплазія келихоподібних клітин, війчаста гіперплазія, плоскоклітинна метаплазія та десквамація епітелію. У разі важкого нападу бронхіальної астми (астматичний статус) відзначаються набряк, розширення капілярів, відшарування слизової оболонки бронхів, руйнування їі клітин. Підслизові тканини набряклі і містять безліч еозинофілів, опасистих клітин, лімфоцитів та плазмоцитів. Особливу роль серед багатьох клітин запалення відіграють еозинофіли, які $\epsilon$ біомаркерами бронхіальної астми. Запальний процес охоплює всі структури стінки бронха: епітелій, базальну мембрану, лімфоїдні вузлики, пов'язані з бронхами, судини, гладкі м'язи. Важливим фактором запалення є порушення кровообігу в бронхах. Посилення проникності посткапілярних венул пов'язано 3 утворенням ендотеліальних отворів і підвищенням внутрішньосудинного тиску. Ексудація плазми сприяє проникності клітин запалення у слизову оболонку.

Епітелій є першою ланкою, яка контактує з аерополютантами. Контакт 3 подразником викликає його часткові структурні зміни, а в подальшому вся поверхня слизової оболонки бронхів зазнає значних змін. За допомогою електронної мікроскопії існує можливість рахувати кількість опасистих клітин, нейтрофілів та еозинофілів у біоптаті слизової оболонки дихальних шляхів. Руйнування епітелію і дегрануляція опасистих клітин спостерігаються навіть у хворих, які страждають на астму помірного ступеня протягом нетривалого (менше одного року) часу у найбільш стабільному періоді захворювання.

Особливо важливим є питання щодо наявності, термінів виникнення, ступеня важкості та характеру запалення стінки дихальних шляхів у дитячому віці. Труднощі діагностики в ранньому віці, тенденція до спонтанного одужання або полегшення нападів, не завжди вдалі спроби прогнозування перебігу захворювання нерідко викликають у практичних лікарів сумніви щодо необхідності тривалої протизапальної терапії. Принципово важливою $є$ та обставина, що ознаки запалення в дихальних шляхах виявляються в дитячому віці не тільки у разі важкого, але й у разі середньоважкого перебігу бронхіальної астми, в тому числі, в періоді клінічного благополуччя. Вираженість запальних змін корелює зі ступенем бронхіальної обструкції та тривалістю захворювання. Під час мікроскопічного дослідження біоптатів бронхів дітей, хворих на бронхіальну астму, виявляються деформація, потовщення та злущування циліндричного епітелію, потовщення базальної мембрани, мукоїдне набухання і гіаліноз базальної мембрани, гіперплазія слизових залоз. 
Для бронхіальної астми характерним є синтез безлічі хімічних медіаторів запалення, проте ключову роль відіграють цистеїнові лейкотрієни (ЛТ). Вони виконують роль не тільки потужних бронхоконстрикторів, але й беруть участь у підвищенні проникності судин i гіперсекреції слизу, вивільненні нейропептидаз, впливають на активацію еозинофілів, гіпертрофію гладких м язів бронхів і депозицію колагену. Різке підвищення рівня ЛТ особливо часто спостерігається під час проведення бронхопровокаційних тестів 3 алергеном, фізичним навантаженням, холодним повітрям i аспірином. Показано, що інгібітори синтезу ЛТ і антагоністи їх рецепторів частково або повністю блокують констрикторну відповідь бронхів на різні тригери.

Провідну роль у реалізації запалення у разі бронхіальної астми відіграють інтерлейкіни (IL) - розчинні пептиди, що виконують функції імунорегуляторів локальної дії. Виділено близько тридцяти окремих типів інтерлейкінів, які різняться за структурою, фізико-хімічними властивостями та спектром біологічної активності. Інтерлейкін-5 (IL-5) секретується Tлімфоцитами, лаброцитами й еозинофілами. Це головний цитокін, що відповідає за проліферацію та дозрівання еозинофілів, регулює передачу сигналу 3 Т- на В-лімфоцити, сприяе дозріванню клітин, що утворюють антитіла. Інтерлейкін-8 (IL-8) продукується моноцитами, нейтрофілами, виконує роль індуктора гострої запальної реакції, бере участь у хемотаксисі нейтрофілів, стимулює ріст Т-лімфоцитів і модулює синтез IgE В-лімфоцитами, активованими IL-4.

У значної частини дітей i дорослих 3 важким і тривалим перебігом бронхіальної астми у разі біопсії виявляються ознаки фіброзу. Розвиток незворотних змін при неконтрольованій астмі можливий вже через 4 роки після початку захворювання. 3 часом у стінці бронхів розвиваються дифузне хронічне запалення, потовщення та гіаліноз базальної мембрани, склероз міжальвеолярних перетинок. Наступними етапами стає збільшення гіпертрофії м'язів, хвороба дрібних дихальних шляхів, їх перебудова (ремодуляція) та склероз. У хворих 3 гормонозалежною астмою виявляються незворотні пневмосклеротичні зміни.

Хронічне запалення дихальних шляхів - один 3 ключових феноменів бронхіальної астми. Слід відзначити, що недостатню ефективність базисного лікування бронхіальної астми, певною мірою, пов'язують із гетерогенністю запального процесу в дихальних шляхах, а саме з наявністю еозинофільного, нейтрофільного та пауцигранулоцитарного характеру їх запалення. Низький вміст еозинофільних i нейтрофільних лейкоцитів у мокротинні визначає пауцигранулоцитарний (гранулоцитарнопенічний) запальний фенотип бронхіальної астми ( $<3 \%$ еозинофілів і $<51-65 \%$ нейтрофілів). За наявності нейтрофільного характеру запального процесу в бронхах, знижується контроль над бронхіальною астмою з розвитком ознак ï терапевтичної резистентності. 
Це вимагає індивідуалізованого підходу до лікування. Дана вимога є особливо актуальною, оскільки протягом останніх років відмічається чітка тенденція до підвищення рівня захворюваності на неалергічну бронхіальну астму, в основі якої, зазвичай, лежить нееозинофільний характер запалення бронхів. Варто відзначити, що сучасний менеджмент бронхіальної астми переважно базується на уявленні про еозинофільний характер запалення дихальних шляхів.

Характеризуючи основні клітини, які реалізують запальний процес при бронхіальній астмі, в першу чергу треба описати опасисті клітини (тканинні базофіли). Вони найчастіше зустрічаються в органах, функція яких пов'язана із захисними механізмами. У дихальних шляхах ці клітини містяться у сполучній тканині lamina proprie та в бронхіальному епітелії. Первинна захисна роль опасистої клітини полягає у мобілізації імунної реакції на місці локалізації патогенного фактору. Дегрануляція опасистих клітин відбувається після іхх активації під впливом алергену. Вони $є$ відповідальними саме за специфічне запалення. Дегрануляція опасистих клітин супроводжується вивільненням чинників анафілаксії і хемотаксисом еозинофілів. Крім того, були описані медіатори, що мають здатність залучати і стимулювати нейтрофіли й інші клітини.

Опасисті клітини здатні виділяти рецептор з високою спорідненістю до $\operatorname{IgE}$, який через включення T / В клітинної взаємодії призводить до продукції IL-4 та IL-13 й індукує синтез IgE.

Як уже згадувалося, біомаркерами бронхіальної астми вважаються еозинофіли, а еозинофільна інфільтрація дихальних шляхів може служити для диференціації цього захворювання від інших запальних станів.

Еозинофілія периферичної крові, мокротиння i тканини бронхів розглядалася як патогенетичний синдром астми ще на початку XX ст. Еозинофіли складають від 1 до 4\% загальної кількості лейкоцитів (120-350 клітин на 1 мм3). Вони мають характерну зернистість, приблизно 200 гранул на клітину. У гранулах містяться високоосновні білки, які виявляються в місцях пошкодження епітелію, в залозах і на базальній мембрані, що призводить до пошкодження дихальних шляхів у хворих, які страждають на астму. Ці специфічні білки призводять до руйнування фагоцитарних рецепторів на нейтрофілах. Їхнє збільшення спостерігається під час загострення бронхіальної астми і корелює з тяжкістю захворювання. Вказані вище білки впливають на базофіли крові, опасисті та нервові клітини, що може змінювати бронхіальну гіперреактивність. Активність еозинофілів вимірюється концентрацією специфічних протеїнів у мокротинні або сироватці.

Еозинофіли $є$ прозапальними клітинами, які можуть продукувати медіатори запалення (PAF, LTC4), що викликають підвищення проникності судин і бронхоконстрикцію. Крім того, еозинофіли виступають модуляторами алергічних реакцій, адже вони містять субстанції здатні інактивувати гістамін, 
LTC4, LTD4, LTE4, PAF, гепарин, пригнічувати дегрануляцію тучних клітин і базофілів. Еозинофіли - переважно тканинні клітини. На одну клітину, що циркулює у крові, припадає 50-200 еозинофілів в кістковому мозку і 100 у тканинах. Їх рівень у периферичній крові пов'язаний 3 певним циркадним ритмом, максимум якого припадає на нічні години, мінімум - на ранкові. На концентрацію еозинофілів у крові і інших біологічних середовищах впливає період захворювання і проведене лікування. Найбільша кількість цих клітин визначається у разі аспіринової астми. Лікування глюкокортикостероїдами, $\beta_{2}$ агоністами, теофіліном та кромонами знижує число еозинофілів і їх продуктів в крові, мокротинні і рідині бронхоальвеолярного лаважу Стероїди істотно знижують тривалість життя еозинофілів, призводять до їх загибелі за механізмами апоптозу.

Активну роль в ушкодженні епітелію бронхів у разі астми відіграють також нейтрофіли. Збільшення еозинофілів і нейтрофілів у вогнищі запалення характерно для пізньої астматичної відповіді. У хворих з середньо важким перебігом i незначною тривалістю захворювання у слизовій оболонці виявляється дуже мало нейтрофілів. Їх кількість підвищується у хворих 3 важкою бронхіальною астмою, які страждають упродовж кількох років. Нейтрофільна інфільтрація пов'язана з пізньою стадією патологічного процесу, наявністю інфекції дихальних шляхів, похилим віком хворого.

Для бронхіальної астми також характерними є активність тромбоцитів, їх залучення в запальний процес і підвищення агрегації. Тромбоцити зазнають істотної морфологічної перебудови, зменшується тривалість їх життя. У разі атопічної та аспіринової бронхіальної астми визначається високий вміст фактору активації тромбоцитів, який викликає швидке, пряме підвищення мікросудинної проникності і, як результат, набряк, стимулює продукцію слизу підслизовими залозами бронхів. Взаємодія білків плазми зі слизом призводить до утворення слизових корків, типових для бронхіальної астми.

Протягом останніх років встановлено, що в умовах загострення алергічного процесу відбувається активація метаболізму арахідонової кислоти і пов'язана 3 нею гіперпродукція ейкозаноїдів. Синтез ліпідних медіаторів залежить від типу клітин і ферментних систем, що метаболізують арахідонову кислоту. Серед великої кількості медіаторів, які беруть участь у розвитку запалення у разі бронхіальної астми, саме лейкотрієнам належить провідна роль. Джерелами лейкотрієнів $є$ альвеолярні та перитонеальні моноцити, моноцити крові, нейтрофіли, еозинофіли, базофіли, опасисті клітини, тканинні макрофаги. В результаті впливу провокаційних чинників відбувається активація та дегрануляція цих клітин. Лейкотрієни мають велику кількість біологічних ефектів, які клінічно проявляються потужною констрикцією гладких м'язів, набряком слизової оболонки і секрецією слизу в просвіт бронхів. Наприклад, LTC4 та LTD4 виявляють у 1000 разів більшу спастичну дію на судини, ніж 
гістамін, маючи при цьому дозозалежний ефект. Крім прямого впливу індукції бронхоспазму, лейкотрієни здатні збільшувати продукцію мокротиння не тільки у хворих, але й у здорових людей. Доведена роль лейкотрієнів щодо вивільнення інших прозапальних агентів, особливо фактору, що активує тромбоцити. Лейкотрієни відіграють ключову роль у патогенезі аспірінової астми й астми фізичного навантаження. Пацієнти, чутливі до аспірину, виділяють підвищену кількість LTE4 3 сечею, а також LTC4 3 назальним секретом після прийому аспірину.

Суттєве значення в патогенезі бронхіальної астми відіграє нейрогенна регуляція, особливо адренергічна та холінергічна іннервація. У виникненні гіперчутливості дихальних шляхів основну роль відіграють такі механізми як вивільнення медіаторів із сенсибілізованих клітин, запалення слизової оболонки бронхів і нейрогенна регуляція. Іннервація дихальних шляхів людини здійснюється гілками n. vagus i волокнами з верхніх п'яти торакальних гангліїв, які утворюють в ділянці кореня легені переднє і заднє сплетення. 3 останніх беруть початок перибронхіальне та периартеріальне сплетення. Крім регулювального впливу на тонус гладких м`язів, автономна нервова система впливає на секрецію слизу, ступінь проникності і об’єм кровоплину в судинах, на вивільнення медіаторів клітинами запалення.

Аферентні рецептори, які реагують на подразнення (наприклад, дим, двооксид сірки, пил, холодне повітря), розташовуються на бронхіальному епітелї і у стінках альвеол. Стимуляція парасимпатичних нервових закінчень викликає бронхоконстрикцію від трахеї до бронхіол. Цей механізм має певне значення в гіперреактивності бронхіального дерева у разі бронхіальної астми. Адренергічних нервових волокон у гладких м'язах бронхів менше, їх подразнення викликає бронходилятацію. Існування між клітинами величезної кількості міжклітинних зв'язків щілинного типу сприяє поширенню медіаторів i електричної активності на всю м'язову масу. Центр вегетативної регуляції функцій міститься в гіпоталамусі: в передньому відділі - парасимпатичний, у туберальному та задньому відділах - симпатичний. Рівень нейросекреторної активності гіпофіза визначається співвідношенням його медіаторів: норадреналіну, серотоніну й ацетилхоліну та контролюється вищими структурами мозку, а також за рахунок зворотного гуморального зв'язку. Цей контур забезпечує стійку рівновагу між симпатичним та парасимпатичних відділами периферичної іннервації, а також синтез адаптивних гормонів через ланцюг: кортикотропін - релізинг-фактор гіпоталамуса - адренокортикотропний гормон гіпофіза - гормони надниркових залоз. Периферична регуляція пов'язана 3 особливостями дії основного стресового гормону - адреналіну, що $\epsilon$ інтегратором різних клітинних функцій.

Упродовж доби тонус симпатичного i парасимпатичного відділів вегетативної нервової системи змінюється. У вечірній, нічний і ранковий час 
активність симпатичного відділу істотно нижча. Посилення парасимпатичного впливу в ці години сприяє виникненню нічних нападів БА.

Особливе значення в реалізації бронхіальної астми відіграє адренергічний дисбаланс. Теорія ß-адренергічного дисбалансу атопії виникла ще в 60-і роки. Суть їі полягає в тому, що у хворих на бронхіальну астму $\epsilon$ дисфункція адренорецепторів зі зниженням Љ-адренорецепторної регуляції та відносним переважанням $\alpha$-рецепторної. Функціональна стабільність рецепторів регулюється за допомогою центрального і периферичного контурів. $\mathrm{B}_{2}$-адренорецептори численно розташовані в легенях людини на епітеліальних клітинах і в стінках альвеол; в меншій мірі - в гладких м'язах дихальних шляхів i судин, а також у підслизових залозах. Молекулярна структура системи $\beta_{2}$ адренорецептора включає у себе рецептор клітинної поверхні, гуаніннуклеотидзв'язуючий білок, який відіграє роль регулятора (регуляторна субодиниця аденілатциклази) в зв'язуванні агоніст-рецепторної взаємодії 3 активацією або гальмуванням третього компонента - каталітичної субодиниці аденілатциклази. Комплекс гормон + рецептор + гуанін-нуклеотидзв’язуючий білок $\epsilon$ посередником гормонального стимулювання швидкості активації аденілатциклази. Синтез циклічного аденозинмонофосфату (цАМФ) вторинного внутрішньоклітинного посередника залежить від активності аденілатциклази. Стимуляція $\beta_{2}$-адренорецепторів призводить до збільшення внутрішньоклітинної концентрації цАМФ й активації ферментів, які фосфорилюють білки, відповідальні за релаксацію. Таким є прямий шлях міорелаксації. Крім цього, здійснюється опосередкований вплив на тонус гладких м язів за рахунок регуляції мукоциліарного кліренсу.

Зниження чутливості $\beta_{2}$-адренорецепторів до адреналіну ( $\beta$-блокада за Szentivanyi) порушує гомеостатичний баланс, викликає недостатність аденілатциклази і підвищує тонус бронхів незалежно від того, який фактор (інфекційний, фізико-хімічний або психічний) є пусковим механізмом.

Питання про те, чи існує первинний адренергічний дисбаланс, чи дисфункція рецепторів розвивається у процесі захворювання, залишається дискусійним. Більшість авторів вважають дефекти рецепторної системи такими, що не залежать від форми захворювання.

Порушення $\beta$-адренорецепції у хворих на БА $\epsilon$ генералізованим, визначається за допомогою функціональних, біохімічних і метаболічних тестів i тісно корелює 3 важкістю захворювання. Значне зниження кількості $\beta_{2}$ адренорецепторів у лімфоцитах периферійної крові відзначається в період загострення бронхіальної астми, а також у хворих 3 важким перебігом захворювання. Дисфункція $\beta_{2}$-адренорецепторів особливо виражена у разі розвитку бронхіальної астми в літніх осіб. Часткова блокада (десенситизация)

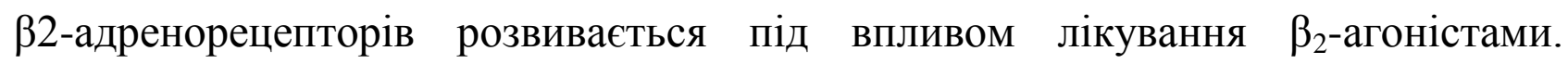
Десенситизація рецепторів під впливом симпатоміметиків зіграла велику роль в 
збільшенні смертності від бронхіальної астми в 60-70 роки у Великобританії та Новій Зеландії, тому доречно ще раз нагадати про небажаність курсового застосування $\beta 2$-агоністів короткої дії.

Втрата чутливості рецепторів відбувається в результаті самого алергічного запалення. Роботи багатьох авторів показують, що інгаляції специфічних алергенів сенсибілізованими до них хворими супроводжуються зниженням кількості ß-адренорецепторів лімфоцитів периферичної крові. Існує зв'язок між важкістю перебігу бронхіальної астми і втратою чутливості адренорецепторів. 


\section{КЛІНІКА БРОНХІАЛЬНОЇ АСТМИ}

Клінічна картина бронхіальної астми складається з періодів загострення та ремісії.

Загострення бронхіальної астми - це епізоди прогресуючого погіршення, що характеризуються задишкою, кашлем, свистячими хрипами, відчуттям стискання в грудній клітці, розладом дихання. Об'єктивним критерієм важкості обструкції дихальних шляхів $є$ визначення функції зовнішнього дихання.

Напад ядухи - це різко виражена задишка, що межує 3 асфіксією. Утруднене дихання при цьому відчувається головним чином на видиху, задишка має експіраторний характер.

За перебігом ремісії захворювання у бронхіальній астмі виділяють так звану «медикаментозну ремісію», або контроль захворювання, коли усунення проявів захворювання відбувається на фоні базисної терапії, та власне класичний період ремісії, коли відзначається повне усунення симптомів захворювання після відміни базисної терапії.

Найтиповішим проявом бронхіальної астми є напад ядухи.

Нападовий період нерідко починається 3 провісників. Хворий стає дратівливим, збудженим, порушується сон, іноді спостерігаються біль голови, втома. Характерними є зміни настрою, які найчастіше виявляються в депресії і тривожних передчуттях. У певної групи маленьких пацієнтів підсилюються невротичні симптоми: тики, логоневроз. Виникають різні за характером i інтенсивністю прояви риносинусопатії (чхання, “алергічний салют”, серозні виділення 3 носа). Іноді хворий скаржиться на свербіння і печію в горлі, покашлювання, яке часто переростає у нападоподібний кашель. Нерідко спостерігається свербіння очей і шкіри.

Період провісників може тривати від декількох хвилин, годин до кількох днів, після чого розвивається типовий напад ядухи з вираженою експіраторною задишкою. Видих супроводжується свистячими хрипами, які чути на відстані. Намагаючись полегшити дихання, хворий займає вимушене положення. Він сидить, нахилившись уперед і опираючись на руки, намагається зафіксувати плечовий пояс і видихнути. Мова утруднена. Хворий вимовляє короткі окремі фрази.

Лице бліде 3 ціанотичним відтінком. В акті дихання беруть участь допоміжні м`язи мускулатура плечового поясу, спини, черевної стінки, роздуваються крила носа, втягуються на вдиху міжреберні проміжки i надключичні ямки. Грудна клітка при цьому роздута, мало зменшується у об'ємі на видиху. На відстані чути короткий "хапаючий" вдих і болісний, розтягнутий видих. Під час перкусії над легенями визначається коробковий 
звук. Аускультація легень дозволяє виявити дихання з подовженим видихом, масу сухих свистячих хрипів.

Свистячі хрипи високого тону вислуховуються над всією поверхнею легенів, з’являються ділянки "німої легені", що свідчить про важкий стан хворого і в більшості випадків характеризує початок важкого нападу. Численні тріскучі хрипи низького тону, зменшення експіраторної задишки та продуктивний кашель, які супроводжують полегшення стану хворого, свідчать про закінчення нападу. Мокротиння у разі бронхіальної астми в'язке, склоподібна, в кінці нападу можливе відходження зліпків - "рисових зерен" та спіралей Куршмана. При інфекційному процесі кількість мокротиння збільшується, воно набуває жовтого або жовто-зеленого кольору.

Під час рентгенологічного дослідження реєструються підвищена прозорість легеневих полів, низьке стояння діафрагми. Ребра розміщенні горизонтально, міжреберні проміжки широкі. Легеневий рисунок підсилений, корені легень розширені.

Прогностично несприятливим є зникнення хрипів над легеневими полями під час наростання ступеня задухи. У разі ускладненого перебігу сухі хрипи зникають переважно у нижніх відділах легенів, де вислуховуються ділянки "німої легені" або з’являється крепітація через початкові ознаки набряку. Така картина є найбільш характерною для поєднаної легенево-серцевої патології.

Іноді спастичний кашель виступає як самостійний клінічний варіант бронхіальної астми (напад кашлю не переростає у задуху). Задуху пов'язують із втомою респіраторних м'язів у відповідь на збільшений опір дихальних шляхів. I кашель, і задуха спрямовані на подолання бронхообструкції, але призводять до розвитку патологічного кола.

Важкість нападу задухи можна оцінити клінічно й об'єктивізувати за допомогою функції зовнішнього дихання, яка має найбільшу цінність до початку розвитку нападу. Під час аури, на тлі бронхоспазму, що починається, порушується носове дихання, з'являється почуття "закладеності у грудях", спостерігається швидка зміна настрою. Зниження показників форсованого видиху $\left(\mathrm{OФB}_{1}\right.$, ПОШ $\left._{\text {вид }} 50 \%, 75 \%\right)$ дає кількісну характеристику ступеня бронхообструкції. На висоті нападу, особливо важкого, немає необхідності досліджувати ФЗД, адже зусилля, витрачені на проведення дослідження, не виправдовують отриману інформацію.

У більшості хворих напади виникають вночі або під ранок.

Після кожного нападу обов'язково спостерігаються явища післянападового бронхіту, які тривають від 1-3 днів до 1-3 тижнів і довше.

Бувають випадки, коли напад бронхіальної астми затягується, бронхолітична терапія не дає бажаного ефекту і розвивається важкий стан, який характеризується формуванням стійкої обструкції дихальних шляхів, що зумовлює вентиляційно-перфузійні порушення. Останні призводять до 
розвитку гіпоксемії, гіперкапнії, зміни кислотно-основного стану крові. Такий стан може розвинутися дуже швидко. Важкий напад бронхіальної астми, який триває понад шість годин на фоні резистентності до бронхолітичної терапії, донедавна трактували як астматичний стан. В останніх узгоджувальних документах не рекомендують користуватися цим терміном, а запропонований термін «важкий напад астми» або «загрозлива для життя астма».

Поява сучасних способів інгаляційного подавання ліків i широке впровадження базисної терапії значно скоротили кількість важких приступів бронхіальної астми, однак і сьогодні слід пам'ятати про можливість розвитку важкого нападу астми, який характеризується резистентністю до симпатоміметиків i знімається тільки системними кортикостероїдами. Його основними ознаками $\epsilon$ десенситизація $\beta 2$-адренорецепторів, нечутливість до бронхолітиків, порушення дренажної функції бронхів, виникнення гіпоксемії та гіперкапнії. Клінічно спостерігаються виражені обструктивні порушення (бронхоспазм, набряк і гіперсекреція), мозаїчно з’являється повна обструкція бронхів, приєднуються рестриктивні ураження - обмеження дихальної поверхні за рахунок ателектазів різної величини, можливий пневмоторакс або набряк легень. Зазвичай хворий сидить, намагається фіксувати грудну клітку. Спостерігається виражена задишка, дихальні рухи здійснюються за участі дихальних м'язів. Перкуторний звук коробковий, на тлі ослабленого дихання вислуховуються хрипи високого тембру, кількість яких стає все меншою через повну обструкцію бронхів (зони "німої легені"). Наростає тахікардія, можливий парадоксальний пульс (зниження наповнення пульсу на вдиху), системний артеріальний тиск підвищений.

Глибина дихальної недостатності збільшується відповідно до порушення механіки дихання, альвеолярної вентиляції та збільшення артеріовенозного шунтування. У нормі легеневі капіляри є механічним фільтром, що затримує мікроемболи, агрегати тромбоцитів тощо. У разі порушення реології крові в дрібних судинах різко зростає кількість клітинних, фібринозних i жирових мікроемболів, що призводить до блокади капілярного фільтру, набряку інтерстицію та зниження продукції сурфактанту. Посилюються артеріальна гіпоксемія ( $\mathrm{PaO}_{2}$ 50-60 мм рт. ст.), а також гіперкапнія ( $\mathrm{PaCO}_{2}$ 50-70 мм рт. ст.).

На тлі глибокої гіпоксії та гіперкапнії можуть розвинутися порушення психіки - збудження, що змінюються втратою свідомості і маренням.

У випадку надважкого загострення астми шкіра різко ціанотична, дихання часте, поверхневе. При аускультації дихальні шуми практично не вислуховуються ("німа легеня"). Спостерігається тахікардія, порушення ритму серця, парадоксальний пульс. Артеріальний тиск падає. Гіпоксемія сягає 40-50 мм рт. ст., гіперкапнія - 80-85 мм рт. ст і вище, знижується об'єм циркулюючої крові та позаклітинної рідини. Високий ступінь гіперкапнії призводить до нового порочного кола - посилюється гіпоксія за рахунок впливу надлишку 
CO2 на криву дисоціації гемоглобіну, що порушує синтез оксигемоглобіну в легенях. Підвищується викид катехоламінів, посилюються спазм артеріол і реологічні розлади кровоплину, зростає периферичний опір. Збільшена (на початку) скорочувальна здатність міокарда поступово змінюється пригніченням, з'являються порушення ритму серця.

Причинами розвитку важкого нападу астми можуть бути такі фактори:

1. Передозування 及2-агоністів - найчастіша причина у пацієнтів "зі стажем". Хворий вважає "інгалятор" єдиним засобом, який йому допомагає, i може збільшити кількість інгаляцій (значно більше ніж 6-8 на добу).

2. Медикаментозна алергія на тлі прийому нестероїдних протизапальних препаратів. Найчастіше ці стани розвиваються у хворих похилого віку при недостатньо уважного ставлення медичного персоналу. Невинна на перший погляд таблетка індометацину може послужити початком важкого загострення астми.

3. Реакція на призначення $\boldsymbol{\beta}$-адреноблокаторів у хворих із коморбідною патологією. Препарати середньої та навіть високої селективності щодо $\boldsymbol{\beta 1 -}$ рецепторів можуть посилювати адренергічний дисбаланс, що призводить до обтяження стану хворого на астму. Абсолютно протипоказані неселективні $\beta$ адреноблокатори (пропронолол).

4. Медикаментозна алергія на тлі прийому антибіотиків. Більшість антибіотиків діють як гаптени, ковалентно зв'язуються із білками й утворюють 3 ними комплекси, здатні стимулювати вироблення антитіл. Алергічну реакцію може викликати будь-який антибіотик, але найчастіше причиною $є$ антибіотики пеніцилінового ряду.

5. Масивний контакт зі специфічним алергеном. Найчастіше виникає при поєднанні астми з полінозом і характеризується швидким розвитком за типом анафілаксії.

2. Тривала експозиція алергену на виробництві (професійна астма). Реакція може розвиватися як за негайним, так і за сповільненим типом.

3. Синдром відміни при терапії кортикостероїдами частіше спостерігається у асоціальних хворих. Безвідповідальне ставлення до свого здоров'я нерідко призводить до розвитку надважких загострень астми.

Перебіг важкого нападу астми та його прогноз залежать від важкості бронхіальної астми і супутніх захворювань, від причини розвитку та своєчасно наданої допомоги. Значною мірою обтяжують стан легеневе серце, серцева астма, гормональна залежність, діабет та інші причини.

На особливу увагу заслуговує дитяча астма, яка не завжди перебігає типово. Іноді вона виявляється в періодичних нападпх сухого кашлю або свистячого видиху (wheezing) без вираженої задишки.

Найскладнішою є діагностика бронхіальної астми у дітей перших 5 років життя, оскільки епізоди свистячих хрипів і кашель - найчастіші симптоми 
різноманітних захворювань органів дихання у цьому віці. Згідно даних багатьох дослідників, бронхообструктивний синдром реєструється у 10-30\% дітей перших 5 років життя. Це зумовлено анатомо-фізіологічними особливостями органів дихання, внаслідок чого запальний набряк і гіперсекреція легко блокують вузькі дихальні шляхи. В силу анатомо-фізіологічних особливостей раннього дитячого віку бронхообструкція у разі бронхіальної астми частіше зумовлена набряком слизової оболонки бронхів і гіперсекрецією слизу, що зумовлює картину так званої «вологої астми у дітей», коли при аускультації на фоні дихання 3 подовженим видихом вислуховується велика кількість дрібнопухирчастих хрипів. Клінічна картина нападу астми у таких дітей нагадує клініку гострого бронхіоліту.

У дітей до 5 років діагноз бронхіальної астми встановлюється виключно на підставі даних анамнезу та результатів клінічного спостереження, оскільки не має валідних маркерів/критеріїв для верифікації діагнозу бронхіальної астми у дітей даної вікової групи. Більшість науковців і практичних лікарів вважають, що вірогідність діагнозу бронхіальної астми у дітей перших 5 років життя збільшується за наявності $\geq 3$ епізодів свистячих хрипів, пов'язаних 3 дією тригерів, сімейного анамнезу астми (особливо у матері) та клінічних проявів атопії у вигляді атопічного дерматиту, харчової алергії та/або алергічного риніту, еозинофілії крові й ефективності пробної бронхолітичної та протизапальної терапії протягом не менш 8-12 тижнів.

Таким чином, на сьогодні існує єдиного рецепту щодо алгоритму дій лікаря у разі рецидивного бронхообструктивного синдрому у дітей раннього віку, не існує специфічних маркерів для діагностики астми в цей віковий період. Потрібні тривале спостереження і ретельна диференціальна діагностика.

Про бронхіальну астму у дитини треба подумати за наявності таких даних :

- $\quad$ атопічний анамнез

- періодичність виникнення симптомів : три епізоди бронхообструкції протягом 1 року (ядуха, свистяче дихання, нападоподібний кашель), які найчастіше підсилюються вночі і під ранок;

- виникнення загострень, спровокованих дією алергенів i фізичним навантаженням

В таких випадках призначається пробна базисна протизапальна терапія, ефективність якої підтверджує діагноз.

Критерії важкості загострення бронхіальної астми у дітей представлені у Додатку 


\section{ФУНКЦІОНАЛЬНЕ ДОСЛІДЖЕННЯ ЛЕГЕНЬ ТА МЕТОДИ ДІАГНОСТИКИ ЗАПАЛЕННЯ ДИХАЛЬНИХ ШЛЯХІВ ПРИ БРОНХІАЛЬНІЙ АСТМІ}

Легенева вентиляція - це конвективне перенесення газу по дихотомічно поділених повітроносних шляхах (бронхах і бронхіолах) до термінальних та респіраторних бронхіол і безпосередньо альвеол де і відбувається дифузійне перенесення кисню та вуглекислого газу через альвеолярно-капілярну мембрану до крові та у зворотному напрямку. Дрібні повітроносні шляхи в нормі у дорослих і дітей старше 14 років створюють близько $10 \%$ загального опору диханню, у дітей ця цифра значно вища і в окремих випадках складає близько $30 \%$.

У разі бронхіальної астми особливо збільшусться опір дрібних повітроносних шляхів. Обмеження руху повітря найбільш виражене у разі форсованого дихання. Під час форсованого видиху відбувається компресія повітроносних шляхів внаслідок того, що плевральний тиск підвищується. Дрібні повітроносні шляхи, де тиск реєструється менший за внутрішньо плевральний піддаються колапсу. Фронт зрівнювання внутрішньо плеврального та внутрішньоальвеолярного тисків у хворих на бронхіальну астму переміщується до альвеол в результаті чого повітроносні шляхи спадаються на значному протязі, затримуючи повітря ще більшого об'єму. Це зменшує об'єм форсованого видиху за 1 с $\left(\mathrm{OФB}_{1}\right)$ та швидкості потоку на різних ділянках форсованої життєвої ємності легень (ФЖЕЛ). Зменшується пікова об'ємна швидкість видиху (ПОШ обструкції дрібних повітроносних шляхів різко падають швидкості потоку в кінці видиху.

Функція зовнішнього дихання у хворих на бронхіальну астму залежить, в першу чергу, від періоду хвороби ( контролю бронхіальної астми).

Функціональне дослідження легень включає в себе як звичайну спірографію (пневмотахографію), так і складніші тести. Скорочені позначення показників легеневої функції представлені в таблиці 1.

Таблиия 1

Параметри функції зовнішнього дихання

\begin{tabular}{|l|l|l|}
\hline \multicolumn{2}{|c|}{ Параметри } & Скорочення \\
\hline $\begin{array}{l}\text { Максимальний об'єм повітря, який видихається 3 } \\
\text { прикладанням форсованих зусиль після максимально } \\
\text { глибокого видиху - форсована життєва ємність легень, л }\end{array}$ & ФЖЄЛ \\
\hline Об'єм повітря, що видихається після максимально & ЖЕЛвд \\
\hline
\end{tabular}




\begin{tabular}{|c|c|}
\hline $\begin{array}{l}\text { глибокого видиху у разі максимально глибокому вдиху - } \\
\text { життєва ємність легень, л }\end{array}$ & \\
\hline $\begin{array}{l}\text { Об'єм повітря, що видихається } 3 \text { прикладанням } \\
\text { форсованих зусиль протягом першої секунди - об'єм } \\
\text { форсованого видиху за першу секунду, л }\end{array}$ & $\mathrm{OФB}_{1}$ \\
\hline Відношення ОФВ 1 до ФЖЄЛ, \% & $\mathrm{OФВ}_{1} / Ж Е Л$ \\
\hline Відношення ОФВ1 до ЖСЛ - індекс Тіффно, \% & IT \\
\hline $\begin{array}{l}\text { Середня об'ємна швидкість на ділянці від } 25 \% \text { до } 75 \% \\
\text { об'єму ФЖЄЛ на видоху } 3 \text { прикладанням форсованих } \\
\text { зусиль - середня об'ємна швидкість на ділянці від } 25 \% \text { до } \\
75 \text { \% ФЖЄЛ, л/с }\end{array}$ & СОШ $25-75$ \\
\hline $\begin{array}{l}\text { Максимальний об'ємний розхід на видиху з прикладанням } \\
\text { форсованих зусиль - пікова швидкість видиху, л/с }\end{array}$ & ПШВ \\
\hline $\begin{array}{l}\text { Миттєвий об'ємний розхід на рівні видиху } 3 \\
\text { прикладанням форсованих зусиль, рівна } 25 \% \text { ФЖЄЛ - } \\
\text { миттєва об'ємна швидкість }\end{array}$ & $\mathrm{MOШ}_{25}$ \\
\hline $\begin{array}{l}\text { Миттєва об'ємна швидкість на рівні видиху } 3 \\
\text { прикладанням форсованих зусиль, рівна } 50 \% \text { ФЖЄЛ - } \\
\text { миттєва об'ємна швидкість на рівні видиху } 50 \% \text { ФЖЄЛ, } \\
\text { л/с }\end{array}$ & MOШ $_{50}$ \\
\hline $\begin{array}{l}\text { Миттєвий об'ємний розхід на рівні видиху } 3 \\
\text { прикладанням форсованих зусиль, рівний } 75 \% \text { ФЖЄЛ - } \\
\text { миттєва об'ємна швидкість на рівні видиху } 75 \% \text { ФЖЄЛ, } \\
\text { л/с }\end{array}$ & $\mathrm{MOШ}_{75}$ \\
\hline
\end{tabular}

Для діагнозу бронхіальної астми найбільшого значення набули динамічні легеневі об'єми, які відображають стан дихальних шляхів. Зміна цих об'ємів реєструється в часі на спірограмі при виконанні прийомів, що використовуються для визначення ФЖЄЛ. Об'єм повітря, що видихається форсовано за першу секунду після повного вдиху $\left(\mathrm{OФB}_{1}\right)$, в нормі перевищує 75\% ЖЄЛ. Цей об'єм часто виражається у відсотках ЖЕЛ (ОФВ 1 ЖЕЛ) і носить назву індексу Тиффно. Об'ємна швидкість форсованого видиху, усереднена за певний період вимірювання, отримала назву максимальної об'ємної швидкості (МОШ). Чутливим показником щодо обструкції дихальних шляхів є МОШ на рівні 5075\% значень форсованої ЖЄЛ. 
Найбільш практичним та інформативним у клінічній практиці є запис діаграми потік-об'єм, яку отримують шляхом безперервної реєстрації цих двох параметрів на електронному спірометрі на глибокому вдиху i форсованому видиху. Форма діаграми відображає стан легеневих об'ємів та дихальних шляхів упродовж усього дихального циклу.

Загострення бронхіальної астми найчастіше проявляється обструкцією периферичних бронхів i реєструється у вигляді зниження швидкостей форсованого видиху в другій половині кривої "потік-об'єм" на рівні 50-75\% ЖЄЛ (МОШ 50-75). Зниження швидкостей потоку на кривій "потік-об'єм" упродовж всього форсованого видиху і особливо на початку (МОШ 25, ПОШ вид) вказує на генералізований характер обструкції. Під час нападу бронхіальної астми реєструється порушення прохідності на всіх рівнях дихальних шляхів, причому рух потоку повітря утруднюється не лише під час форсованого, але i при спокійному диханні.

Після нападу відновлення функції легень відстає від клінічного поліпшення. Коли у хворого вже немає відчуття задухи і утрудненого дихання, бронхіальна прохідність, за даними функціональних досліджень, ще залишається порушеною практично в усіх хворих, а після зникнення свистячих хрипів - у половини. Нормальні показники функції зовнішнього дихання в періоді ремісії бронхіальної астми не означають відсутності гіперреактивності бронхів.

Для об'єктивізації респіраторної функції, особливо в амбулаторних умовах, для встановлення максимально точного діагнозу та моніторингу стану хворого використовується пікфлоуметрія (Додаток 4). Завдяки простоті, швидкості, точності вимірювання і доброго відтворення результатів цей метод $\epsilon$ основним для контролю стану хворого з астмою за допомогою ФЗД (ПОШ вид).

Вимірювання ПОШ вид (PEF) за допомогою пікфлоуметрії особливо корисне у таких випадках:

1. Для амбулаторного контролю астми (щоденник самоконтролю). Характеристика денного патерну дихання (ранкові та вечірні виміри ) дозволяє робити висновки про зміну стану дихальних шляхів. Існують відпрацьовані номограми для дорослих і дітей, які дозволяють порівняти показники пацієнта 3 нормативами відповідно до статі, віку та зросту. Добові коливання показників пікфлоуметра обов'язково обговорюються 3 лікарем та служать гарною підмогою для розробки індивідуальної карти лікування пацієнта. Значення ПОШ вид від 100 до 80\% не викликають побоювань щодо базисної терапії, яка може вважатися достатньою (зелена зона). Зниження показників до 80-60\% вказує на негативну клінічну динаміку та небезпеку загострення, що вимагає посилення терапії (жовта зона). Зниження показників до 70-50\% говорить про необхідність екстреної консультації 3 лікарем i, можливо, стаціонарного лікування (червона зона). 
Різниця показників ПОШ вечірнім виміром характерна для астми. Прогресивне зниження показників порівняно з належними свідчить про погіршення клінічного стану, загострення процесу.

2. Другим важливим моментом $\epsilon$ об'єктивізація фармакологічної проби. Різниця ПОШ $\beta 2$-агоніста, $\epsilon$ патогномонічною для астми. Фармакологічний тест проводиться всім хворим з ПОШ вид нижче 80\% від належних величин. Однак на практиці індивідуальні показники зазвичай варіюють від 80 до 100\%, а також можуть бути вищими за середньостатистичні нормативи. Проведення фармакологічної проби в цьому випадку дозволяє виявити прихований бронхоспазм.

3. Крім фармакологічних тестів, пікфлоуметрія застосовується для контролю за тривалим базисним лікуванням. Щоденне дворазове відстеження показників ПОШ порівняти стан пацієнта до і після курсу лікування.

4. Метод дає можливість виявити пускові механізми бронхоспазму специфічні або неспецифічні тригери. У разі епізодичного відхилення показників до і після дії подразників пікфлоуметрію можна використовувати для виявлення тригерних чинників у будинку, на робочому місці, під час зміни погоди (холод, вогкість). Однак, з огляду на перехресну дію тригерів, це не завжди вдається.

5. Пікфлуометрія показана в разі важких нападів бронхіальної астми, коли більш складніші методи не можуть бути застосовані через важкість стану хворого.

6. Простота і швидкість методу важлива як в педіатричній практиці так i у дорослих пацієнтів.

Одним з ключових феноменів бронхіальної астми є хронічне запалення дихальних шляхів, тому на особливу увагу заслуговують методи його діагностики. Прямим, найбільш достовірним методом оцінки ступеня запалення в нижніх дихальних шляхах $\epsilon$ фібробронхоскопія зі взяттям біопсійного матеріалу - бронхоальвеолярний лаваж. Незважаючи на високу інформативність і цінність цього методу, він не може широко застосовуватися для діагностики та лікування БА. Існує спеціальна група показань використання бронхоскопії при цьому захворюванні, що обмежує коло пацієнтів.Дослідження мокротиння, виділення якого провокується інгаляцією гіпертонічним розчином, дозволяє оцінити рівень запалення дихальних шляхів за кількістю епітелію, за активацією еозинофілів, макрофагів, лімфоцитів та опасистих клітин (відповідно до рівня гістаміну) у хворих на бронхіальну астму. Дані, отримані цим методом, тісно корелюють з результатами бронхоальвеолярного лаважу, але сама процедура більш прийнятна для хворого з бронхообструкцією.

Останнім часом значна увага приділяється дослідженню рівня оксиду 
азоту (NO) в повітрі, що видихасться. У хворих на бронхіальну астму, на відміну від здорових, у епітелії бронхів запускається циклооксигеназний шлях розвитку 3 індукцісю NO-синтетази. В результаті біохімічних реакцій 3 L-аргініну синтезується NO, рівень якого можна зареєструвати в повітрі, що видихається. Паралельно 3 цим, NO-синтетаза втручається в продукцію інтерлейкіну-1 $\beta$ та TNF- $\alpha$, значно підвищуючи ці цитокіни у хворих на астму порівнянно зі здоровими людьми. Ступінь верифікації визначення NO в повітрі, що видихається в порівнянні 3 прямою біопсією під час фібробронхоскопії досягає 90\%.Таким чином, дослідження рівня NO у повітрі, що видихається $\epsilon$ маркером мукозного запалення. Реєстрація даних відбувається за допомогою хемолюмінісцентного детектора, з'єднаного з комп'ютером. Підвищення рівня NO в повітрі, що видихається тісно корелює 3 активністю процесу запалення при бронхіальній астмі. Протирецидивна терапія ІКС знижує концентрацію NO. Дослідження є швидким, простим у виконанні і має високу чутливість та добру повторюваність. За достатнього технічного забезпечення цей метод має велике майбутнє у практичній охороні здоров'я.

У хронічний запальний процес у разі бронхіальної астми втягується безліч різних клітин. Запалення характеризується активацією та затуханням, що, в свою чергу, призводить до різного ступеня звуження просвіту бронхів i зміни товщини бронхіальної стінки - ремодуляції. Десятиліттями астма вважалася захворюванням з повністю оборотною обструкцією, проте багато пацієнтів (особливо з важким перебігом), причому і дорослі, і діти відзначають стійку, тривалу обструкцію.

Короткі напади, що швидко виникають, добре знімаються $\beta 2$-агоністами, в той час як пролонгована бронхообструкція супроводжується тривалим порушенням легеневої функції і погано піддається дії $\beta 2$-агоністів. Таке тривале загострення з порушенням легеневої функції пов'язано зі стійким хронічним запаленням, яке підтримується активованими еозинофілами та їх медіаторами. У таких випадках запобігти розвитку загострення може базисна терапія із застосуванням інгаляційних кортикостероїдів (ІКС).

Незважаючи на гетерогенність захворювання, спільним для нього $\epsilon$ обмеження функції зовнішнього дихання. У дорослих контролем може служити динаміка показника ОФВ 1 , який прогресивно знижується 3 віком. У пацієнтів з астмою різке зниження легеневої функції відзначається у віці 50-60 років. Ремодуляція притаманна всім варіантам астми, проте при алергічній астмі цей процес найповільніший. Більше того, у пацієнтів 3 неалергічною астмою, що почалася після 50 років, рівень ОФВ 1 , буде достовірно нижче, ніж у хворих того ж віку, які з юності страждали на алергічну астму. Ремодуляція бронхів має морфологічне, функціональне та радіографічне підтвердження. За допомогою комп'ютерної томографії можна виявити потовщення бронхіальної стінки, бронхоектази та емфізему, але в разі неалергічної астми відзначаються 
більш виражені зміни. Зміни в структурі мукозного шару вивчаються за допомогою бронхіальної біопсії. У субмукозному шарі відзначаються потовщення м'язових волокон і гіпертрофія залоз, що виробляють слиз, а також збільшення діаметра судин. Це, в свою чергу, призводить до стійкого потовщення бронхіальної стінки i перманентного зменшення калібру дихальних шляхів. Кортикостероїди є основною групою препаратів, здатних зменшити товщину базальної мембрани. Найефективнішим $\epsilon$ раннє призначення IКС, тобто до того моменту початку потовщення стінки.

В цьому контексті особливою $є$ позиція педіатрів і сімейних лікарів, які мають шанс не допустити розвитку ремоделювання шляхом вчасного призначення ІКС.

Незважаючи на безсумнівний ефект ІКС у цілому, серед дітей і дорослих існують групи хворих, нечутливих до пропонованої терапії. Виходячи 3 патогенезу, терапія щодо стабілізації ремодуляції бронхів повинна бути постійною. 


\section{СПЕЦИФІЧНА АЛЕРГОДІАГНОСТИКА}

Специфічна алергодіагностика дозволяє виявити алергени, які призводять до розвитку і прогресування загострень бронхіальної астми. Сьогодні іiі можливості суттєво розширилися від анамнестичних даних, шкірних скарифікаційних та прик-тестів, специфічної алергодіагностики in vitro 3 визначенням специфічних $\mathrm{IgE}$ до компонентної (молекулярної) діагностики алергії. Більше того, сьогодні ми говоримо про сучасні можливості об'єктивізації прик- тестів за допомогою методу Prick film, який дозволяє автоматично відчитати і роздрукувати результат тестування і не допускає помилок, пов'язаних з людським фактором. Водночас треба відзначити, що результати всіх додаткових методів алергодіагностики можуть бути контроверсійними 3 клінікою, тому рекомендовано проводити паралельно і шкірні прик-тести, і визначення специфічних антитіл. Добрим вважається результат, коли тести узгоджуються між собою, у противному разі мусимо шукати пояснення таких результів.

Сьогодні для проведення шкірного алерготестування в Україні застосовують стандартний набір алергенів виробництва ТОВ «Імунолог» (Україна) і «Діатер» (Іспанія).

Для підтвердження атопічної природи захворювання проводиться імунологічне дослідження з визначенням загального $\operatorname{IgE}$ сироватки крові.

Успіхи в галузі рекомбінантних алергенів призвели до розробки нової концепції діагностики алергії - діагностики на підставі компонентів алергенів, або молекулярної діагностики алергії. Нині вченими виявлено та охарактеризовано велику кількість компонентів алергенів із різних джерел і цей перелік у процесі наукового прогресу постійно зростає. Зокрема, виділені 15 молекулярних компонентів алергенів кліщів домашнього пороху. Найбільші алергенні властивості мають мажорні компоненти Dermatophagoides pteronyssinus (Der p1, Der p2), Dermatophagoides farinae ( Der f1, Der f2) і мінорні компоненти Der p10 i Der f10 - тропоміозини. Ці компоненти алергенів відрізняються між собою за здатністю зв'язувати антитіла, зокрема імуноглобуліни класу E та G4, що лягло в основу поділу компонентів алергенів на головні (або мажорні) (антитіла до них виявляють у більше $50 \%$ сенсибілізованих осіб) і другорядні (або мінорні) (антитіла до них виявляють менше ніж у $10 \%$ хворих).

Для проведення молекулярної алергодіагностики в Україні найчастіше використовують імунофлюоресцентний метод ImmunoCAP («Phadia AB», Швеція). Матеріалом дослідження є сироватка крові. 


\section{ВІКОВА ЕВОЛЮЦІЯ БРОНХІАЛЬНОЇ АСТМИ: ВІД ДИТИНИ ДО ДОРОСЛОГО}

Не зважаючи на значні поступи в розумінні сутності бронхіальної астми й опрацювання нових ефективних терапевтичних програм, у значному відсотку випадків захворювання, стартувавши в дитинстві продовжується і в дорослому віці. Протягом останніх років спостерігається зростання зацікавлення проблемою вивчення зв'язку „дитячої” i „дорослоі” астми. Проведення довготривалих досліджень вікової еволюції астми показало, що бронхіальна астма зникає у 30-50 \% дітей у пубертатному періоді, але часто відновлюється в дорослому віці. Більше того, сьогодні доведено, що, навіть за умови зникнення клінічних ознак бронхіальної астми, функція легень у пацієнтів часто залишається порушеною i утримуються ознаки гіперреактивності бронхів.

Протягом останніх років отримані неоднозначні результати щодо вікової еволюції астми. Одні автори стверджують, що бронхіальна астма у дітей переважно має сприятливий прогноз і часто закінчується спонтанним одужанням у пубертатному віці. Інші доводять, що захворювання у 40-70 \% пацієнтів, які стали дорослими, продовжується, і нерідко легкий перебіг трансформується у важкий.

Найскладнішою $є$ діагностика БА в ранньому дитячому віці, оскільки епізоди свистячих хрипів та кашель - найчастіші симптоми при різноманітних захворюваннь органів дихання у дітей перших років життя. На думку деяких дослідників, чим молодша дитина, тим більша ймовірність того, що епізоди повторних свистячих хрипів не $\epsilon$ астмою. Повторний бронхообструктивний синдром у дітей раннього віку розвивається при багаточисельних вроджених та набутих станах: це різноманітні вади розвитку нижніх дихальних шляхів та судин легень, муковісцидоз, первинна циліарна дискінезія, туберкульозний бронхоаденіт, сторонні тіла трахеї та бронхів, гастроезофагальний рефлюкс, набуті стенози трахеї, новоутвори середостіння тощо. Доведено, що більшість указаних вище захворювань як і бронхіальна астма вперше проявляють себе на фоні респіраторної інфекції. Діагностичні критерії захворювань, що супроводжуються розвитком бронхообструктивного синдрому у дітей представлені у таблиці 2. Таким чином, немовлята і малі діти 3 рецидивами свистячого видиху звичайно становлять для педіатра значну діагностичну проблему.

Дані стосовно прогнозу і наслідків бронхіальної астми у дітей раннього віку є неоднозначними. Деякі дослідження свідчать про несприятливий прогноз захворювання, якщо астма розвивається у дітей молодше 3 років (крім тих випадків, якщо вона розпочалась на фоні вірусних інфекцій). 


\section{Діагностичні критерії захворювань , що супроводжуються розвитком БОС у дітей}

\begin{tabular}{|c|c|}
\hline Нозологічні одиниці & Діагностичні критерії \\
\hline $\begin{array}{l}\text { Інфекційний } \\
\text { обструктивний } \\
\text { бронхіт чи бронхіолі }\end{array}$ & $\begin{array}{l}\text { Вірусологічні та бактеріологічні } \\
\text { дослідження }\end{array}$ \\
\hline $\begin{array}{l}\text { Бронхолегенева } \\
\text { дисплазія }\end{array}$ & $\begin{array}{l}\text { Анамнез навколопологовий, } \\
\text { рентгенографія, газометрія }\end{array}$ \\
\hline Муковісцидоз & $\begin{array}{l}\text { Вміст хлоридів у поті, генетичні } \\
\text { маркери }\end{array}$ \\
\hline $\begin{array}{l}\text { Аспірація } \\
\text { стороннього тіла }\end{array}$ & $\begin{array}{l}\text { Анамнез, рентгенографія, } \\
\text { бронхоскопія }\end{array}$ \\
\hline $\begin{array}{l}\text { Гастроезофагальний } \\
\text { рефлюкс }\end{array}$ & 24-годинна рН-метрія \\
\hline Імунодефіцити & Імунологічні дослідження \\
\hline $\begin{array}{l}\text { Синдром нерухомих } \\
\text { війок }\end{array}$ & $\begin{array}{l}\text { Гістологічні дослідження слизової } \\
\text { оболонки носа або бронхів }\end{array}$ \\
\hline $\begin{array}{l}\text { Вади розвитку } \\
\text { дихальних шляхів }\end{array}$ & $\begin{array}{l}\text { Рентгенографія, бронхоскопія, } \\
\text { комп’ютерна томографія }\end{array}$ \\
\hline $\begin{array}{l}\text { Вади розвитку } \\
\text { системи кровообігу }\end{array}$ & $\begin{array}{l}\text { Рентгенографія з контрастуванням } \\
\text { стравоходу, комп'ютерна } \\
\text { томографія, ехокардіографія }\end{array}$ \\
\hline Туберкульоз & $\begin{array}{l}\text { Туберкулінова проба, } \\
\text { рентгенографія, бронхоскопія, } \\
\text { бактеріологія }\end{array}$ \\
\hline $\begin{array}{l}\text { Пухлини } \\
\text { середостіння }\end{array}$ & $\begin{array}{l}\text { Рентгенографія ОГК, } \\
\text { бронхоскопія , комп’ютерна } \\
\text { томографія }\end{array}$ \\
\hline
\end{tabular}

Сьогодні доведено, що особливо важливим, свого роду переломним періодом щодо прогнозу бронхіальної астми, $\epsilon$ пубертатний вік. Це пояснюється не лише гормональною перебудовою організму, який починає функціонувати в абсолютно іншому ритмі, але й зміною психо-емоційного фону дитини. Саме в період підліткового віку починається найбільш важливий 
час формування особистості дитини, iї вподобань, амбіцій, ставлень до світу.

Підлітки вступають в доросле життя, але думають ще не так як дорослі, i вже не так, як менші діти. Психологічна неврівноваженість підлітків (демонстративність у висловлюваннях, інтонаціях і поведінці, егоцентризм) призводять до неоднозначної реакції на лікування і зниження рівня співпраці 3 лікарем. У ставленні до свого здоров'я, підлітки часто проявляють протилежні тенденції - від надмірної турботливості до байдужості. 3 ними батькам трудно знайти спільну мову, вони не звертаються до лікаря, а родичі через втрачені контакти вже не можуть контролювати лікування (втрачається контроль бронхіальної астми). Підлітки часто самовільно перестають приймати лікування через відсутність симптомів хвороби, або через забуття. Прикладом проблемного вживання ліків може бути відмова підлітків від інгаляційної терапії, пов'язана 3 особливостями становлення психоемоційного статусу в цьому віці, значним впливом оточення на поведінку підлітка, небажанням його виглядати хворим в очах однолітків. Все це суттєво впливає на перебіг БА в цьому віковому періоді .

До факторів, які визначають прогресування бронхіальної астми в підлітковому віці перш за все відносять жіночу стать (статевий поліморфізм “ендокринної революції”). Погіршення клінічного перебігу у дівчаток зумовлене гормональним дисбалансом, особливо вираженим у передменструальному періоді і пов'язаним 3 порушенням співвідношення естрогени/прогестерон. Високий вміст естрогенів виявляє стимуляційний вплив на імунну відповідь і робить організм дівчинки особливо вразливим до дії тригерних факторів. Проблему збільшуюють надмірне вживання $\beta 2$-агоністів короткої дії, низька толерантність до спеціальних освітніх программ щодо астми, супутня соматична патологія, особливо ураження шкіри алергічного генезу. Вживання психоактивних речовин (алкоголь, тютюнопаління, наркотики) та перший статевий досвід часто роблять підлітків абсолютно некерованими.

Окремі дослідники відзначають зростання частоти смертей серед осіб молодого віку. За даними багатьох епідеміологічних досліджень, критичним $€$ препубертатний та пубертатний періоди, оскільки близько 80 \% смертей при бронхіальній астмі припадає на віковий інтервал 11-16 років.

Протягом останніх років виявлені також окремі фактори ризику розвитку бронхіальної астми, важкість якої з віком прогресує. Серед них - наявність активного “еозинофільного” ендобронхіту та/або збереження його після лікування, наявність супутнього активного неспецифічного інфекційного процесу в бронхах, невиправдане призначення пероральних кортикостероїдів (КС) без невикористаних можливостях інгаляційної КС-терапії, несприятлива атмосфера у сім'ї. 
Результати досліджень, що стосуються зв'язку “дитячої“ та “дорослоі““ астми, неоднозначні. Зокрема, окремі автори вважають, що бронхіальна астма у дорослих не є продовженням “дитячої” астми.

Одним з найбільших проспективних, є дослідження D.R.Taylor et al., які провели спостереження за 1137 дітьми від народження до досягнення ними 26річного віку і резюмували: сьогодні не може бути сумніву в тому, що трансформація дитячої астми в дорослу в контингентах високого ризику відбувається, переломним є пубертатний вік.

Таким чином, протягом останніх років уявлення про бронхіальну астму як про єдину хворобу все більше залишаються в історичному минулому. Переважна більшість науковців та практиків розглядають їі як надзвичайно гетерогенне захворювання, яке потребує не лише фенотипової деталізації, але й анализу вікової динаміки, оцінки еволюції і прогнозу перебігу хвороби. 


\section{ПЕРЕБІГ БРОНХІАЛЬНОЇ АСТМИ ПІД ЧАС ВАГІТНОСТІ ТА ЇЇ ВПЛИВ НА ПЛІД}

Вплив ендокринного фону жінок на перебіг бронхіальної астми починається в пубертатному періоді та позначається упродовж всього життя. В першу чергу мають значення фази менструального циклу і його вікові закономірності. Багато пацієнток, хворих на астму, відмічають погіршення стану i почастішання нападів через наближення менструації. Існує взаємозв'язок між дисменореєю та частотою нападів астми. Погіршення перебігу захворювання часто спостерігається у зв'язку з клімаксом, причому корекція його за допомогою естрогенів посилює важкість і ускладнює контроль над астмою.

У періоді вагітності у третини жінок полегшується перебіг бронхіальної астми, у третини - погіршується, у решти - стан не змінюється.

Збільшена кількість статевих гормонів, в першу чергу, прогестерону, під час вагітності стимулює легеневу вентиляцію. Збільшення вентиляції легенів відбувається за рахунок зростання числа дихальних циклів, підвищення активності реберних м'язів, що компенсують обмеження дихальних екскурсій діафрагми. Внаслідок гіпервентиляції фізіологічний алкалоз вагітних накладається на алкалоз, характерний для бронхіальної астми. Під час вагітності зростає рівень кортизолу в крові та активність гістамінази, а отже, знижується можливість виникнення бронхоспазму. Погіршення стану частіше розвивається у пацієнток 3 важким висхідним перебігом захворювання i поганим самопочуттям в першому триместрі вагітності.

Розвиток гіпоксії вагітних справляє негативний вплив на плід. Немає переконливих даних, що свідчать про вплив важкості бронхіальної астми на розвиток внутрішньоутробних дефектів і смерті плода, що пов'язано, мабуть, із захисними резервами плода в умовах гіпоксії матері. Однак доведено, що існує взаємозв'язок між несприятливим перебігом бронхіальної астми у матері і недоношеністю, зниженням маси тіла новонародженого та збільшенням неонатальної смертності.

Під час вагітності необхідним є психологічний тренінг, спрямований на ліквідацію тривожного стану. Особливе значення має поліпшення самоконтролю та контролю лікаря за перебігом захворювання, негайна відмова від куріння (якщо це мало місце), гіпоалергенна дієта, профілактика респіраторних захворювань. Слід проявляти обережність щодо трансформаційних змін медикаментів, в першу чергу, антибіотиків, нестероїдних протизапальних препаратів, препаратів йоду тощо. 
Базисна терапія бронхіальної астми, а також терапія нападів повинні бути під ретельним контролем. Категоричних протипоказань під час вагітності жоден $з$ протиастматичних препаратів не має, але вони проникають через плацентарний бар'єр, тому необхідність їх призначення повинна ретельно зважуватися. Водночас загострення, що виникло вимагає негайної ліквідації, через те, що гіпоксія матері негативно впливає на плід. Призначення інгаляційних кортикостероїдів в терапії бронхіальної астми у переважній більшості випадків не супроводжується шкідливою дією на плід, тому воно є показаним для підтримки ремісії та запобігання загостренню. Однак, необхідно пам'ятати, що тривале лікування гормонами, особливо системними, може спричинити тератогенну дію, затримку розвитку сполучної тканини плода, гіпоглікемію і наднирковий криз у новонароджених. 


\section{БРОНХІАЛЬНА АСТМА У ДОРОСЛИХ І КОМОРБІДНІ СТАНИ}

Поєднання бронхообструктивного синдрому із захворюваннями інших органів і систем значно погіршує стан пацієнта, якість життя та прогноз, особливо в похилому віці. Адже вплив на якість життя визначається двома, або кількома захворюваннями, асоціюється 3 високим рівнем летальності і багато в чому залежить від супутніх патологічних станів.

В сучасній літературі поняття коморбідності - ураження двох і більше органів (систем) характеризується перебігом або за типом синтопії, що означає їх одночасне ураження під впливом єдиних патогенетичних факторів, або за типом інтерференції - виникнення одного захворювання під впливом іншого. За всієї різноманітності формулювань найповніше коморбідність можна визначити як такі патологічні порушення, які при кількох захворюваннях мають єдині етіологічні або патогенетичні механізми і зустрічаються частіше ніж в загальній популяції.

За статистичною звітністю, серед причин смерті, що переважають у хворих похилого віку з бронхообструкцією, стоять артеріальна гіпертензія та ішемічна хвороба серця. Артеріальна гіпертензія вкрай негативно впливає на внутрішньолегеневу гемодинаміку та бронхіальну прохідність, на перебіг бронхіальної астми, особливо під час нападів та тривалих загострень. Крім того, накладаючись на вікові зміни судин - склероз, гіаліноз та атрофію гладких м'язових волокон в артеріях дрібного діаметру, артеріальна гіпертензія ускладнюється посткапілярною легеневою гіпертензією 3 подальшим набряком інтерстиціальної тканини i формуванням пневмосклерозу. На тлі рестриктивних змін, що виникли, бронхообструкція втрачає свою зворотність. Стійка бронхообструкція, гіпоксія тканин та венозна легенева гіпертензія призводять до підвищення навантаження на праві відділи серця. 3 іншого боку, бронхообструкція з нападами задухи $є$ потужним стресовим фактором негативного впливу на перебіг артеріальної гіпертензії. Незалежно від типу гемодинаміки характерним $\epsilon$ поступове зниження ударного і хвилинного об'ємів і їх індексів, зростання периферичного опору, збільшення числа серцевих скорочень. У хворих на бронхіальну астму страждає діастолічна функція як правого, так і лівого шлуночка, причому у літніх людей ці зміни більш виражені, що обумовлено віком. Результати морфологічних досліджень свідчать про високу частоту атеросклерозу аорти i коронарних артерій у таких хворих. Поєднання цих патологічних станів призводить до синдрому «взаємного обтяження» i погіршує прогноз захворювання. В популяції ризик смерті від серцево-судинних захворювань у хворих з бронхообструкцією становить приблизно 50 \% від загальної кількості смертельних випадків. 
Окрім взаємного негативного впливу 3 боку дихальної та серцевосудинної систем, який відбувається з віком під впливом їх еволюції, важливою є зміна самого бронхообструктивного синдрому.

У дорослих найчастіше проводиться диференційний діагноз між бронхіальною астмою та хронічним обструктивним захворюванням легень (ХОЗЛ). У разі обох захворювань існує обмежена прохідність дихальних шляхів на тлі хронічного персистуючого запалення. Відмінності відзначаються на рівні клітинних механізмів, медіаторів запалення, особливостей запального процесу та відповіді на медикаментозну терапію. Еозинофільне запалення у разі бронхіальної астми впливає на гіперреактивність бронхів та поширюється на всі дихальні шляхи. Для астми не характерний фіброз. Характер запалення у разі ХОЗЛ переважно нейтрофільний, відмічається паренхіматозна деструкція, яка визначає жорстке (погано зворотнє) обмеження бронхіальної прохідності, що $є$ важливим критерієм ХОЗЛ. Куріння призводить до розвитку ХОЗЛ більш ніж у 90\% пацієнтів.

3 віком, у зв'язку з накопиченням морфологічних змін, пов'язаних 3 емфіземою, пневмосклерозом, деформацією і дистонією бронхів, атрофічним ендобронхітом та склерозуванням судинного русла може зникати чітка грань між перебігом бронхіальної астми і ХОЗЛ. Особливо це характерно для періоду між нападами, коли у хворих на БА відзначається наростання задишки. Порушення функції зовнішнього дихання у таких хворих набуває обструктивно-рестриктивного характеру, в більшості випадків на тлі погано зворотної обструкції. Крім того, природне зниження напруженості імунітету після 40 років може призводити не тільки до загострення хронічних захворювань, але і до трансформації їхніх симптомів. До 40-50 років пацієнт має певний анамнез, який більшою чи меншою мірою пов'язаний 3 бронхіальною обструкцією. Хворі поділяються на дві великі категорії. До першої належать пацієнти, у яких бронхіальна астма почалася 3 дитинства, характеризується вираженою атопією, часто поєднується 3 алергічним ринітом, атопічним дерматитом та іншими проявами атопії. Важкість загострень (за відсутності контролю) наростає поступово протягом усього життя. Клінічна симптоматика характеризується нападами ядухи, що виникають частіше у відповідь на специфічний тригер, можливий нападоподібний кашель як еквівалент "окресленого" нападу ядухи, дихання зі свистом та експіраторна задишка.

До другої категорії належать хворі, у яких бронхіальна астма почалася в другій половині життя. Досить часто це курці, які до появи нападів ядухи вже мали хронічний обструктивний бронхіт. Пусковим механізмом важкого клінічного перебігу бронхіальної астми у другій половині життя може бути пневмонія або вогнище хронічної інфекції, що постійно рецидивує. Важкі 
загострення мають затяжний характер. Провідними компонентами бронхообструкції в цьому випадку є набряк та підвищена секреція мокротиння в результаті вираженого, здебільшого нейтрофільного запалення. Гнійний характер мокротиння вимагає призначення антибактеріальної терапії. Однак такий розподіл теж не може бути абсолютним, адже у половини хворих на бронхіальну астму, з дебютом захворювання у похилому віці, попередньо діагностуються нереспіраторні атопічні прояви.

В кінці 2011 року міжнародна група експертів GOLD (Global Initiative for Chronic Obstructive Lung Disease) представила зведені дані широкомасштабних досліджень щодо ведення пацієнтів з ХОЗЛ та супутніми захворюваннями. В клінічній практиці особливі труднощі у веденні пацієнтів виникають під час загострення бронхообструкції на фоні гіпертонічного кризу. Поєднання ХОЗЛ, ішемічної хвороби серця та бронхіальної астми значно частіше ніж окремі захворювання призводить до різноманітних порушень серцевого ритму. Різний ступінь ураження міокарда та його дисфункції - одна 3 провідних причин раптової смерті у хворих на ХОЗЛ у періоді загострення. Проблема надання медичної допомоги таким пацієнтам на догоспітальному етапі набуває все більшої актуальності в умовах старішання населення та зміщення акцентів у бік амбулаторного лікування. Клінічні рекомендації 3 діагностики і лікування GOLD від 2011 року в розділі ведення пацієнтів 3 коморбідними станами рекомендують притримуватись клінічних настанов щодо основного захворювання з урахуванням особливостей другого і третього діагнозів.

Важливим і своєчасним став програмний документ “ Diagnosis and initial treatment of Asthma, COPD and Asthma-COPD Overlap”, виданий у 2017 році об’єднаними зусиллями експертів GINA та GOLD. Документ окреслює основні ключові положення щодо ведення пацієнтів за неможливості до кінця уточнити діагноз, що особливо важливо для сімейного лікаря (терапевта) первинної ланки.

Зокрема, в документі відзначається, що диференціальний діагноз між астмою та ХОЗЛ може бути проблематичним, якщо захворювання має спільні клінічні риси їх обох, особливо у пацієнтів похилого віку з анамнезом курця. Термін «Asthma-COPD Overlap» найбільше є корисним для лікаря щодо ведення пацієнта 3 поєднаною симптоматикою, адже дослідження, на яких побудовані інші клінічні рекомендації, стосуються окремих захворювань (ідеального хворого).

По суті термін «Asthma-COPD Overlap» не стосується єдиного захворювання і включає пацієнтів з астмою та ХОЗЛ з різними фенотипами, обумовленими різними механізмами.

На первинному етапі «Asthma-COPD Overlap» орієнтує лікаря виконувати правила щодо клінічної ефективності та безпеки пацієнта:

- пацієнтам з симптомами астми для адекватного контролю призначається 
терапія яка перш за все включає IКС;

- $\quad$ пацієнтам з ХОЗЛ призначається відповідне симптоматичне лікування бронходилятаторами або комбінованими препаратами (бронхолітики пролонгованої дії + ІКС), але не монотерапія ІКС;

- $\quad$ пацієнти 3 поєднанням симптомів астми і ХОЗЛ залежно від клінічного стану лікуються низькими або середніми дозами IКС з $\beta_{2}$-агоністами тривалої дії та/або холінолітиками тривалої дії ( за необхідності);

- $\quad$ всі пацієнти з хронічним обструктивним синдромом повинні отримувати терапію спрямована на супутні захворювання.

Консенсус скерований на надання тимчасової допомоги лікарям щодо захворювань на астму та ХОЗЛ, але спонукає до подальшого обстеження хворого, з'ясування патогенетичних механізмів і корекції лікування.

Одним $з$ центральних питань лікування поєднаної патології є зважений підхід до призначення медикаментозних препаратів різних груп та розробка алгоритмів комплексного лікування 3 урахуванням інгаляційної та оксигенотерапії, дихальної гімнастики, рухових режимів і дієти.

Особливого значення набуває своєчасне i коректне призначення препаратів для постійного лікування. «Складним» пацієнтам 3 комбінованим ураженням серцево-судинної та дихальної систем середніх і старших вікових груп рекомендовано розпочинати базисну терапію з препаратів тіотропію або комплексних препаратів - ІКС та бронхолітиків тривалої дії тощо. Пацієнти 3 важким перебігом бронхіальної астми на тлі артеріальної гіпертензії, безперечно, потребують індивідуального комплексного підходу з урахуванням рекомендацій доказової медицини. У додатку 5 ми надаємо основні механізми дії препаратів для лікування пацієнтів 3 коморбідними станами , їх взаємодію та побічні ефекти. 


\section{ЛІКУВАННЯ БРОНХІАЛЬНОЇ АСТМИ}

Лікування бронхіальної астми не $є$ простим і легким завданням. У кожного хворого захворювання може мати якісь свої особливості і вимагати індивідуального підходу до лікування.

I все ж таки існують спільні підходи до лікування, які повинні включати:

1. елімінацію тригерних чинників;

2. специфічну імунотерапію;

3. медикаментозне лікування.

\section{Елімінаційні заходи}

Перш за все треба визначити чинники, які призводять до виникнення загострення бронхіальної астми. Якщо вдається це зробити, треба уникати тригерів або хоча б зменшити їх вплив на організм.

Як цього досягти? За наявності алергії до харчових продуктів треба дотримуватися індивідуально підібраної гіпоалергенної дієти, що не допускає вживання тих продуктів, які викликають алергічну реакцію.

Якщо у хворого спостерігається підвищена чутливість до пилку рослин, необхідно, спираючись на календар цвітіння цих рослин, уникати контакту 3 ними в певні періоди: не гуляти в лісі, в полі, а по можливості навіть виїздити в іншу місцевість у період цвітіння рослини - алергену.

Якщо причиною нападів астми $€$ вплив алергену якоїсь домашньої тварини, необхідно повністю виключити контакт з будь-якими домашніми пташками та тваринами. Щоб не нанести дитині психічної травми слід це робити обережно й делікатно, передаючи тварину або пташку в надійні руки.

Особливі труднощі виникають у разі вираженої побутової сенсибілізації до домашнього пороху, адже повністю позбутися його неможливо. До складу домашнього пороху входить велика кількість різноманітних компонентів: волокна одягу та покриття меблів, лупа та шерсть домашніх тварин, бактерії та спори грибів. Однак основним джерелом алергенів домашнього пороху є кліщі. Вони невеликі за розміром (до 3 мм) і тому невидимі неозброєним оком, однак легко виявляються під час збільшення під лупою або мікроскопом. Знайдені у житлі кліщі прийнято називати домашніми. Харчовим матеріалом для них $\epsilon$ злущений епідерміс людини (звідси назва одного 3 представників родини кліщів Dermatophagoides - той, що харчується шкірою). Найчастіше причиннозначущими щодо побутової сенсибілізації є Dermatophagoides pteronissinus $i$ Dermatophagoides farinae. Найвища концентрація кліщів міститься у поросі із матраців, у подушках з пір'я, килимах, постельній білизні, м'яких меблях.

Виходячи $з$ вказаного вище, на особливу увагу в контексті елімінаційних заходів, заслуговують ті, які зменшують кількість домашнього пороху. 3 цією метою необхідно проводити щоденне вологе прибирання, часто провітрювати 
квартиру, позбутися тих речей, які накопичують пил (м’які меблі, м’які іграшки, штори тощо).

Крім цього треба намагатися створити умови, в яких домашній кліщ не виживає. Відомо, що оптимальними умовами для розвитку кліщів $\epsilon$ температура повітря $+20-30^{\circ} \mathrm{C}$ і вологість вище $55 \%$, а за зниження вологості нижче $45 \%$ і температури +15 C - кліщі гинуть.

Особливу увагу слід надавати спальні хворого. Матраци і подушки необхідно помістити у щільні чохли, щоб позбавити кліщів джерела харчування i вологи. Постіль і ковдри треба регулярно прати (1 раз в тиждень) в гарячій воді (вище $55^{\circ} \mathrm{C}$ ) для гарантованого знищення кліщів. Аналогічний ефект можна отримати просушуванням білизни під сонячними променями, а також провітрюванням їі в морозну погоду взимку.

\section{Фармакотерапія}

Найпоширенішим способом лікування бронхіальної астми і сьогодні залишається фармакотерапія.

Основу лікувальної стратегії у разі бронхіальної астми складають:

- базисна терапія - скерована на ліквідацію хронічного запального процесу, відновлення прохідності бронхів, запобігання розвиткові повторних загострень хвороби і досягнення ремісії;

- терапевтичні заходи, скеровані на ліквідацію загострення хвороби.

Основу базисної терапії складають

недокроміл (тайлед), кортикостероїди;

- $\quad$ пролонговані бронхолітики ( $\beta_{2}$-агоністи, холінолітики, теофіліни);

- антилейкотріснові препарати;

Основу бронхолітичної терапії складають.

- симпатоміметики (найчастіше $\beta_{2}$-агоністи короткої діiі);

- $\quad$ холінолітики;

- препарати метилксантинового ряду;

- $\quad$ комбіновані препарати, до складу яких входять бронходилятатори різних груп (Беродуал).

Безперечно перевага в лікуванні бронхіальної астми повинна надаватися інгаляційним засобам. Відомо, що для досягнення аналогічного ефекту в інгаляції треба ввести значно меншу дозу препарату, ніж парентеральним або пероральним способом, що знижує ризик розвитку побічних ефектів. Інгаляційний спосіб уведення ліків можна застосовувати навіть у немовлят. Введення препарату шляхом інгаляції безпосередньо у дихальні шляхи дає можливість швидше досягти бажаного ефекту і має суттєву перевагу у разі застосування бронходилятаторів у випадках гострого розвитку бронхоспазму. 
Існування на фармакологічному ринку різних типів інгаляторів породжує труднощі у виборі інгаляційної терапії. Протягом багатьох років різними дослідниками описувалися часті випадки неправильного застосування інгаляторів, що, в свою чергу, зводило нанівець ефективність лікування. Тому передумовою ефективного лікування бронхіальної астми $є$ точні відомості про суть і діапазон проблем, з якими стикаються діти, їхні батьки і лікуючий лікар у разі застосування інгаляційного способу терапії.

Під час вибору інгалятора необхідно звернути особливу увагу на вказані нижче важливі чинники. Оптимальним $\epsilon$ інгалятор, який забезпечує рівномірний розподіл більшої частини введеної дози у дихальних шляхах; $є$ найпростішим у застосуванні для конкретного пацієнта, дає найкращий клінічний ефект.

Більшість проблем, які виникають у разі застосування дозованих інгаляторів (велика швидкість аерозолю на виході з мундштука, неможливість скоординувати розбрискування аерозолю й інгалювання), можна вирішити, застосовуючи різні затримні камери (спейсери) 3 масками. Ці пристрої забезпечують сповільнення швидкості частинок аерозолю і зменшують їх розмір, сприяють повнішому випаровуванню пропеленів, а лицева маска, яка приєднана до спейсера, дає можливість використати дозовані інгалятори навіть у дітей грудного віку і спрощує їх експлуатацію. Більшість спейсерів мають клапан однобічної дії, який відкривається під час вдиху і закривається під час видиху. Але під час приступу бронхіальної астми більшість дітей не спроможні внаслідок важкої бронхообструкції правильно відкрити і закрити клапан диханням і таким чином отримати повний терапевтичний ефект. У такому випадку для інгаляційного введення ліків слід застосувати небулайзер (розпилювач).

Треба відзначити, що існують вікові обмеження можливостей інгаляційної доставки ліків у разі бронхіальної астми у дитини. Перш за все завжди існує можливість уведення препаратів шляхом небулізації. Однак мусимо пам'ятати, що в такому випадку застосовується значно більша доза ліку, і їі не треба навіть пробувати порівнювати з автоматично дозованою подачею (pMDI). До досягнення 6 років альтернативною $є$ лише подавання ліку 3 дозованого аерозолю через спейсер. Тільки після 5 років можна працювати 3 сухопорошковими інгаляторами.

Сьогодні ми не можемо переконливо стверджувати, що якийсь конкретний спосіб інгаляційної подачі препаратів $є$ найкращим. Усі мають право на існування і всі диктують потребу формувати певні навички і тому передбачають навчання пацієнта. Ключем до успішного лікування є його індивідуалізація. Немає золотих ліків, не існує найкращих інгаляторів для всіх. Існує вибір в лікуванні, можемо пробувати, відточуючи при цьому своє мистецтво лікування. В цьому контексті дуже актуально звучать слова 
колишнього президента США Джона Кеннеді «Кожна поразка, то є шанс спробувати ще раз, але мудріше».

Навчання хворих техніці проведення інгаляцій 3 подальшим контролем дозволяє суттєво підвищити процент безпомилкового проведення інгаляцій. Лікар повинен не розказати, а показати техніку інгалювання.

\section{Базисна терапія бронхіальної астми}

Основною метою лікування бронхіальної астми є покращання якості життя хворого за рахунок постійного контролю над симптомами захворювання. Щоб цього досягти, необхідно грамотно i тривало лікувати хронічний запальний процес у бронхіальному дереві. I це завдання вирішує базисна терапія.

Основу базисної терапії складають

- протизапальні препарати: натрію кромоглікат (інтал), натрію недокроміл (тайлед), кортикостероїди;

пролонговані бронхолітики ( $\beta_{2}$-агоністи, холінолітики, теофіліни); антилейкотриєнові препарати.

Нестероїдні протизапальні інгаляційні препарати (натрію кромоглікат, натрію недокроміл) добре зарекомендували себе в лікуванні дитячої астми. На жаль сьогодні ці препарати зареєстровані в Україні лише у формі назальних спреїв, хоча, на думку багатьох практичних лікарів, потреба в інгаляційних формах все ж таки існує.

Безперечно найефективнішими препаратами базисної терапії є інгаляційні кортикостероїди (IКС), які, завдяки досягненню високої концентрації у бронхах, забезпечують виражену місцеву протизапальну дію і практично не виявляють системну активність. Однак, на жаль, i нині залишається невирішеним питання уніфікованих рекомендацій для підбору доз ІКС, тривалості лікування i методів контролю за топічною протизапальною терапією. Тому призначення IКС і контроль за лікуванням ними - проблема, яку вирішує лікар індивідуально. Зокрема, ще зовсім недавно для базисної терапії бронхіальної астми у дітей рекомендувалися досить високі дози IКС 3 максимальними коливаннями до 1000-2000 мкг в перерахунку на Беклометазон. Сьогодні така стратегія переглянута в бік суттєвого зниження дозування. Рекомендується вважати для дітей низькими дозами Беклометазону, Будесоніду і Флютиказону - 100 мкг на добу, середніми - 200 мкг на добу, високими - 400 мкг на добу. У разі небулізаційного введення рекомендуються вищі дози, а саме для Будесоніду : низькі дози - 250 мкг, середні - 500мкг, високі -1000 мкг на добу.

Сьогодні трудно уявити свою практичну роботу без ІКС. Ці препарати дали нам можливість контролювати перебіг бронхіальної астми у найскладніших випадках. Однак і сьогодні актуальним залишається питання: 
Чи абсолютно безпечними $є$ інгаляційні глюкокортикостероїди? У цьому плані має рацію відомий алерголог Пітер Барнс, стверджуючи: «Якщо б ІКС не мали побічної дії, ми б уже сьогодні могли сказати, що маємо ідеальний лік для астми». Згідно даних іноземних та вітчизняних науковців і практиків, ризик у разі застосування ІГКС все ж існує, причому найчастіше реєструються місцеві ускладнення у вигляді орофарингеального кандидозу, дисфагії, рефлекторного кашлю. Такі побічні ефекти можна попередити, рекомендуючи застосування спейсерів, полоскання ротової порожнини відразу після інгаляції препарату. I безперечно лікар мусить контролювати правильність застосування IКC пацієнтами. Такий підхід дозволяє звести до мінімуму місцеві побічні ефекти.

Таким чином у разі середньо-важкого і важкого перебігу бронхіальної астми призначаються середні дози ІКС. Однак якщо, призначивши середні дози ІКС, ми не можемо досягти контролю над хворобою, то знову стоїмо перед проблемою вибору терапевтичної тактики. Що можемо зробити :

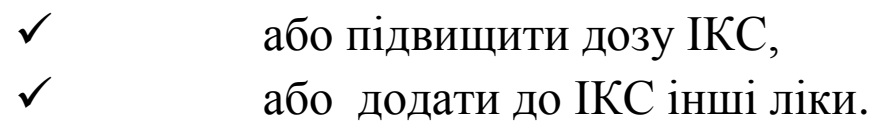

Які ліки можемо додати? На жаль в педіатричній практиці існують певні вікові обмеження.

- $\quad$ До досягнення дворічного віку ми працюємо без альтернативи, маючи лише один вихід - підвищення дозування IКС,

32 до 5 років - можемо додати антилейкотрієнові препарати. Така тактика виглядає досить привабливо особливо, якщо підходити до бронхіальної астми як до хвороби системної (бронхіальна астма + алергічний риніт), про що зараз дуже багато дискутують.

- $\quad$ Значно більше можливостей з'являється після досягнення п'ятирічного віку, коли можна ввести в лікування пролонговані $\beta_{2}$-агоністи.

Практичний досвід доводить, що добрим вирішенням у педіатрії $\epsilon$ призначення середніх доз ІКС у комбінації $\beta_{2}$-агоністами тривалої дії i/aбо антилейкотриєновими препаратами. Однак, треба визнати, що у разі призначення $\beta_{2}$-агоністів тривалої дії нерідко допускаються помилки, які можуть вплинути на перебіг і прогноз захворювання. Перш за все, треба пам'ятати, що вони застосовуються виключно в комбінації з ІКС. Одначе навіть застосування $\beta_{2}$-агоністів тривалої дії в комбінації з IКС не повинно бути довготривалим, не допустиме їх застосування під час загострення бронхіальної астми у дітей. Дотримання таких вимог запобігає розвитку побічних ефектів від застосування $\beta_{2}$-агоністів тривалої дії.

Покроковий алгоритм базисного лікування бронхіальної астми у дорослих представлений у додатку 6. Як тільки розпочато лікування бронхіальної астми, наступні рішення приймаються на підставі покрокової циклової тактики: оцінка ефективності, корекція лікування, оцінка відповіді на терапію. 
Крок 1: $\beta_{2}$-агоністи короткої дії за потреби без призначення контролюючої базисної терапії (лише якщо симптоми виникають рідко, відсутні нічні пробудження через астму, не було загострень упродовж останнього року, нормальний ОФВ 1 ). Інші варіанти: регулярний прийом низьких доз ІКС у пацієнтів з наявністю серйозних факторів ризику загострень.

Крок 2: Регулярний прийом низьких доз ІКС $+\beta_{2}$-агоністи короткої дії за потреби. Інші варіанти: антилейкотрієнові препарати. У разі сезонної алергічної бронхіальної астми негайно розпочати ІКС i припинити їx застосування через 4 тижні після завершення експозиції алергену.

Крок 3. Низькі дози ІКС $+\beta_{2}$-агоністи тривалої дії як базисна терапія. За потреби призначаються $\beta_{2}$-агон

істи короткої дії, або комбіновані препарати ІКС/формотерол. Для пацієнтів, які мали принаймні одне загострення впродовж останнього року, низькі дози беклометазону дипропіонату/формотеролу або будесоніду/формотеролу як засобів базисної i симптоматичної терапії $\epsilon$ ефективнішими ніж терапія із застосуванням ІКС/ $\beta_{2}$-агоністів тривалої дії $+\beta_{2}$ агоністів короткої дії за потреби. Інші варіанти: середні дози ІКС.

Крок 4. Низькі дози ІКС/формотеролу як базисна і симптоматична терапія або середні дози IКС/ $\beta_{2}$-агоністів тривалої дії як базисна терапія та $\beta_{2}$-агоністи короткої дії за потреби. Інші варіанти: тіотропіум (Спіріва) додатково за допомогою аерозольного інгалятора; високі дози IКС/ $\beta_{2}$-агоністи тривалої дії (але така схема має більше побічних ефектів і мало додаткових переваг) для додаткового контролю рекомендуються антилейкотрієнові препарати.

Крок 5: Скерувати на консультацію до алерголога, який розглядає можливості оптимізації лікування. Додаткова терапія полягає в призначенні тіотропіуму, омалізумабу (анти-IgE-препарат) чи меполізумабу (анти-IL-5). Інші варіанти: може бути доцільним призначення деяким пацієнтам низьких доз пероральних кортикостероїдів, проте $\epsilon$ ризик розвитку віддалених системних побічних ефектів.

Наведена схема призначення базисних і симптоматичних препаратів відповідає вимогам доказової медицини і не вимагає широкого обговорення, водночас потребує на особливу застосування в лікуванні важкої астми у дорослих тіотропію броміду (Спіріва). Тіотропій вважається золотим стандартом сучасної терапії ХОЗЛ. Функціональна селективність щодо $\mathrm{M}_{1}$ i $\mathrm{M}_{3}$ холінорецепторів, низька ліпофільність і відповідно, низька системна біодоступність забезпечують високий профіль безпеки препарату.

У більшої частини пацієнтів з персистуючими симптомами захворювання контроль бронхіальної астми може бути досягнутий у разі застосування традиційної фармакотерапії за умови гарної прихильності до лікування i правильної техніки проведення інгаляцій, проте навіть в умовах 
рандомізованих контрольованих клінічних досліджень у суттєвої частини хворих не вдається досягти оптимального рівня контролю хвороби.

Якщо в кінці 1990-х років бронхіальна астма відповідала критеріям контрольованої приблизно у 5-6\% хворих, то вже у 2006 році добрий контроль над хворобою відзначався у 49\% хворих. Однак, протягом останніх років збільшення частки хворих $з$ добрим контролем бронхіальної астми практично не відмічається.

Пацієнти 3 важкоконтрольованою бронхіальною астмою становлять досить велику і складну в лікуванні категорію хворих. Їм частіше, ніж іншим хворим на бронхіальну астму, потрібні підвищення доз препаратів базисної терапії і надання невідкладної медичної допомоги. Крім того, для таких хворих характерна резистентність до базисного лікування, а у частини 3 них формується малозворотна або незворотна обструкція бронхів внаслідок вираженого їх ремоделювання, що, у свою чергу, також сприяє зниженню ефективності лікування. Саме важко контрольована бронхіальна астма завдає значного економічного збитку: на лікування цієї категорії пацієнтів витрачається близько 50\% коштів, призначених для лікування бронхіальної астми в цілому.

У функціональному плані ознаками важко контрольованої бронхіальної астми $\epsilon$ відсутність повної зворотності та різною мірою фіксована бронхообструкція, прискорене падіння ОФВ 1 , збільшення спонтанної або індукованої гіперреактивності бронхів, висока добова варіабельність ОФВ 1 , зниження відповіді на $\beta_{2}$-агоністи. Це пов'язано з тим, що у пацієнтів з важкоконтрольованою бронхіальною астмою в результаті тривалого перебігу захворювання 3 часом розвиваються органічні зміни в стінці бронхів, приєднується незворотня обструкція, посилюється вплив парасимпатичної вегетативної нервової системи. В індукованому мокротинні цієї групи пацієнтів підвищується вміст як еозинофілів, так i нейтрофілів, тобто відбуваються патофізіологічні зміни, характерні більше для хронічного обструктивного захворювання легень.

У зв'язку з цим патогенетично обгрунтованим може бути додавання до базисної терапії холінолітика тривалої дію - тіотропію. Тіотропій, який приймається за допомогою доставкого пристрою Респімат, сьогодні зареєстрований у понад у 50 країнах світу, зокрема і вУкраїні. Додаткова підтримуюча бронхолітична терапія із використанням тіотропію показана для хворих на астму, які отримують терапію комбінацією інгаляційних кортикостероїдів ( $\geq 800$ мкг будесоніду/добу або еквівалент) та $\beta_{2}$-агоністів тривалої дії і які мали одне чи більше тяжких загострень хвороби протягом попереднього року.

Тіотропій має велику доказову базу щодо ефективності та безпеки терапії ХОЗЛ, тому може бути препаратом вибору в якості доповнення до IКС або IКС/ пролонговані $\beta_{2}$-агоністів у пацієнтів з поєднанням бронхіальної астми та хронічного обструктивного захворювання легень (ХОЗЛ). 
Труднощі в досягненні контролю над хворобою стали підставою для суттєвої зміни протягом останніх років концепції контрольованості астми. Оцінка контролю астми передбачає сьогодні не лише оцінку контролю симптомів хвороби, але оцінку майбутніх ризиків загострень (помилки в техніці інгалювання, куріння, зміна екології житла і способу життя тощо). На кожному візиті до лікаря повинен проводитися аналіз наявності коморбідних станів (риніт, риносинусит, гастроезофагальний рефлюкс, ожиріння, нічне апное, соціальні фактори тощо) і оцінка поточного лікування (призначена терапія, техніка інгалювання, прихильність до лікування, побічні ефекти тощо). Враховуючи можливі майбутні ризики відсутності контролю та передбачаючи загрозу загострень, потрібно інтенсифікувати лікування!

Для пацієнта 3 ризиком загострень рекомендовано обов'язкове призначення терапії ІКС, збільшення дози ІКС на короткий період (1-2 тижні) в період підйому захворюваності на гострі респіраторні інфекції та в сезон палінації, створення детального письмового плану лікування астми, частіші візити до лікаря. Нерідко потрібна оптимізація інгаляційної техніки, ключовим елементом якої $є$ редукція помилок пацієнта під час проведення інгаляцій. Цьому сприяє подача ліків в одному типі інгалятора і використаня пристроїв, які дозволяють пацієнтам отримати зворотню інформацію про добре проведену інгаляцію

В останніх міжнародних узгоджувальних документах вже навіть для підлітків в таких ситуаціях рекомендується:

— підвищення дозування комбінованих препаратів (ІКС і пролонгованих $\beta 2$ агоністів)

- збільшення дози ІКС на короткий період (1-2 тижні) - в період підйому ГРІ, в сезон палінації

- Тіотропій поданий через Респімат

Останні редакції узгоджувального документу GINA чітко окреслюють підхід щодо своєчасної корекції терапії на основі регулярної переоцінки ступеня тяжкості i контролю захворювання. Інструментом для цього слугують опитувальники : астма-контроль тест (АСТ) та визначення контролю астми (Додаток 7). Для дітей з важкою неконтрольованою бронхіальною астмою i високим ризиком загострень останні рекомендації пропонують застосовувати Меполізумаб.

Протягом останніх років активно дискутуються підходи до зменшення обсягу базисної терапії. Водночас більшість рекомендаційних документів визнає, що зменшувати об'єм базисної терапії можливо за умови контрольованості бронхіальної астми протягом $\geq 3$ місяців. Сьогодні існують наступні рекомендації щодо алгоритму лікування:

Якщо контроль бронхіальної астми досягнуто на фоні комбінації ІКС і пролонгованих $\beta 2$ - агоністів, віддається перевага зниженню дози IКС на $50 \%$, а пролонговані $\beta 2$ - агоністи продовжують застосовуватися (Рівень доказовості B). Якщо контроль бронхіальної астми утримується, то продовжується зниження дози ІКС до низької, потім можливе 
припинення застосування пролонгованих $\beta 2-$ агоністів (Рівень доказовості D)

• Якщо контроль бронхіальної астми досягнуто на фоні комбінації ІКС i антилейкотриєнових препаратів, віддається перевага зниженню дози ІКС на 50\%, а антилейкотрієнові препарати продовжують застосовуватися (Рівень доказовості В. Якщо контроль бронхіальної астми утримується, то продовжується зниження дози ІКС до низької, потім застосовується монотерапія антилейкотриєновими препаратами (Рівень доказовості D).

Сьогодні переконливо доведено, що існує цілий ряд факторів, в силу яких контроль над бронхіальною астмою залишається недосяжним для значної кількості пацієнтів. До числа таких факторів слід віднести недостатній комплайнс між лікарем і пацієнтом, помилки в техніці інгаляцій, резистентність до IKC i генетичний поліморфізм $\beta_{2}$-адренорецепторів. Таким чином, подальший прогрес у фармакотерапії бронхіальної астми неможливий без нових терапевтичних рішень.

\section{Лікування загострення бронхіальної астми}

У випадку загострення бронхіальної астми препаратами першого ряду є інгаляційні бронхолітики : $\beta_{2}$-агоністи короткої дії (сальбутамол, фенотерол, тербуталін) та комбінований препарат Беродуал, у якому вдало поєднана бронхолітична дія $\beta_{2}$-агоніста Формотеролу та препарату холінолітичної дії Іпратропію броміду.

Препарати короткої дії використовуються лише епізодично, у разі потреби ліквідувати загострення. Якщо ж хворий потребує частого введення цих препаратів - лікування хронічного алергічного запалення є недостатнім. I вихід 3 цієї ситуації треба шукати не в збільшенні частоти інгалювання бронхолітиків короткої дії, а в підсиленні або зміні базисного лікування.

В багатьох європейських країнах для зняття нападів бронхіальної астми у дітей широко користуються препаратом холінолітичної дії - атровентом (іпратропіуму бромідом). Нажаль в Україні цей препарат не зареєстрований, однак

широку популярність здобув комбінований інгаляційний бронхолітичний препарат короткої дії Беродуал, у якому вдало поєднана бронхолітична дія $\beta_{2}$ агоніста Формотеролу та препарату холінолітичної дії Іпратропію броміду. Сьогодні доведено, що в такій комбінації ці препарати мають більш виражений бронхолітичний ефект і тривалішу дію, ніж кожний 3 них окремо взятий. Більше того, комбінація препаратів дозволяє знизити їх дозування (нижча доза кожного з компонентів порівняно з дозами у разі монотерапії), що, в свою чергу зменшує ризик побічних ефектів. Згідно рекомендацій GINA, комбінація $\beta_{2}$ агоністи короткої дії з іпратропієм у хворих із загостренням астми (особливо у дітей) забезпечує кращу бронходилятацію, швидшу позитивну динаміку 
показників зовнішнього дихання і знижує частоту госпіталізацій. Беродуал можна застосовувати у вигляді дозованого аерозолю і у вигляді розчину для небулізаційного введення. Останній спосіб інгаляційного подавання ліку особливо привабливий для дітей, оскільки дозволяє застосувати Беродуал навіть у найменших пацієнтів.

Залишається сьогодні актуальним в лікуванні загострення бронхіальної астми препарат метилксантинового ряду Еуфілін. Еуфілін (амінофілін) часто $\epsilon$ незамінним препаратом у випадку важкого нападу бронхіальної астми, коли необхідним $\epsilon$ його довенне введення. Водночас таке лікування вимагає надзвичайної обережності і ретельного спостереження, оскільки відомо, що між лікувальною дозою препарату і дозою, яка викликає побічні ефекти, дуже незначна різниця, тому весь час існує небезпека передозування. Ця небезпека підтримується ще й тим, що терапевтична доза залежить не лише від віку пацієнта, але й від індивідуальних особливостей метаболізму препарату в організмі.

Під час лікування загострення бронхіальної астми показане застосування IКС, причому перевагу треба надавати ї небулізаційному введенню i дозування повинно бути значно вищим, а ніж при плановій базисній терапії захворювання. Зокрема, дітям з 6 місяців до 12 років призначають $0.5-1$ мг Будесоніду шляхом небулізації 2 рази на добу, підліткам з 12 років - 1 -2 мг 2 рази на добу. Максимальна тривалість призначення вказаної дози - 7 днів після нападу, після чого переходять на звичне для хворого базисне дозування.

Якщо застосування бронхолітиків та IКС не дозволяє зняти напад бронхіальної астми, препаратами вибору залишаються системні глюкокортикостероїди, причому їх дозування коливається у широкому діапазоні (в педіатричній практиці від 1 до 10 мг/кг в перерахунку на преднізолон).

Наявність у разі важкого нападу астми гіпоксемії вимагає ефективної оксигенотерапії.

Алгоритм лікування загострення бронхіальної астми у дорослих представлений у додатку 8.

Після ліквідації нападу бронхіальної астми повинна бути переглянута тактика лікування пацієнта. Перш за все показано збільшити обсяг базисної терапії (Step-up) до моменту повернення симптомів і функції легень до нормальних показників. Загострення часто свідчать про помилки у веденні астми і стають підставою для перегляду терапії. На контрольному візиті необхідно перевірити: розуміння пацієнтом природи загострення, модифікацію факторів ризику (наприклад, куріння), прихильність до лікування, інгаляційну техніку. Візит повинен закінчуватися написанням конкретного плану дій за різних ситуацій. 
Протягом останніх років в Україні досягнутий значний прогрес у лікуванні бронхіальної астми, значно рідше хворі поступають у спеціалізовані стаціонари з важкими нападами астми. Кожна госпіталізація хворого $з$ приводу загострення цього захворювання повинна розглядатися сьогодні як поразка в організації оптимальної базисної терапії у конкретного пацієнта. Однак все ще трапляються пацієнти, у яких розвивається важкий напад астми і навіть виникає потреба проводити штучну вентиляцію легень. Показаннями до переведення хворого на штучну вентиляцію легень $є$ порушення свідомості або збудження, зупинка серця або фатальні аритмії, прогресуючий ацидоз та гіперкапнія, стійка гіпоксемія, пригнічення дихання, виражена втомлюваність дихальних м язів, синдром «німої легені». Сьогодні за умови організації грамотної базисної і симптоматичної терапії бронхіальної астми та дотримання пацієнтом всіх лікарських рекомендацій хворих з важкими нападами астми не повинно бути.

В лікуванні бронхіальної астми і нині існує немало питань, які не мають однозначної відповіді. Зокрема, батьки дуже часто запитують: як довго треба продовжувати лікувати астму у дитини? Досвід роботи Львівського міського дитячого алергологічного центру доводить, що вирішувати це питання завжди не просто і мусить застосовуватися виключно індивідуальний підхід. Сдиного рецепта просто не існує. I в цьому контексті найважливіше - досягти взаєморозуміння 3 пацієнтом і його родиною. Треба «відчувати хворого» $\mathrm{i}$ розумно керувати лікуванням, щоб рішення про відміну терапії не брали на себе батьки. Всі учасники лікувального процесу повинні розуміти, що астма $€$ хронічним захворюванням, яке не зникає навіть тоді, коли загострень хвороби немає, і тому тривале лікування не може перериватися раптово, а повинно продовжуватися місяцями, а за потреби навіть роками. Однак, це не означає, що воно триватиме все життя. При правильному і вчасному лікуванні астму можна тримати під контролем довгий час, що дозволяє поступово зменшувати лікування, а з часом і зовсім його відміняти. 


\section{АЛЕРГЕН-СПЕЦИФІЧНА ІМУНОТЕРАПІЯ БРОНХІАЛЬНОЇ АСТМИ}

Алерген-специфічна імунотерапія (АСІT) дозволяє зменшити чутливість організму дитини до “винного" алергену та знизити активність хронічного запалення. Іммунотерапію почали застосовувати ще з 1902 року. 3 цього часу багаторічний досвід iї застосування довів високу клінічну ефективність методу, яка проявляється тривалим утриманням ремісії бронхіальної астми, запобігання трансформації легких варіантів захворювання у важкі, зменшенням обсягу базисного лікування.

ACIT проводять, застосовуючи очищені водно-сольові екстракти алергенів або виділені із них окремі алергенні компоненти. Цей метод лікування в Україні застосовується у дітей після досягнення 5-тирічного віку, причому його має право проводити виключно лікар-алерголог у спеціально обладнаному кабінеті або алергологічному відділенні лікарні. Для проведення ACIT застосовують лише ті алергени, етіологічна роль яких підтверджена специфічним шкірним алерготестуванням. Цей спосіб лікування у разі бронхіальної астми найчастіше використовується у випадку сезонної пилкової алергії та високої сенсибілізації до кліщів домашнього пилу. Лікування проводиться одним або декількома (за полівалентної сенсибілізації) алергенами. Якщо у хворого виявлено сенсибілізацію до алергенів різноманітних груп, наприклад, кліщових та пилкових, то алергени вводяться окремо в різні кінцівки, краще у різні дні або послідовно (лікування алергенами кліщів починається після закінчення курсу АCIT пилковими алергенами). Традиційно ACIT проводиться шляхом парентерального (підшкірного) та сублінгвального (СЛАСІТ) введення алергенів.

Сьогодні в Україні для проведення АCIT дозволено використовувати алергени виробництва ТОВ «Імунолог» (Україна) та «Діатер» (Іспанія). Як правило, проведення імунотерапії розпочинрають на фоні базисної медикаментозної терапії. Під'язиковий метод терапії передбачає 2 етапи. Впродовж першого етапу (етап ініціації) алерген приймають під язик у зростаючих дозах аж до досягнення максимальної концентрації алергену. Ліки приймають 1 раз на день ввечері (приблизно в один і той самий час) за 30 хв до їжі. Згідно інструкції виробника алергенів, пацієнт може самостійно у разі гострого захворювання чи появи симптомів алергії подовжити інтервал між прийманням чергової дози або знизити дозу алергену. Кожний такий крок узгоджується 3 лікуючим лікарем. Для оцінки сприймання специфічного лікування введення першої дози алергену краще проводити у присутності лікаря-алерголога. Другий етап лікування (підтримуюча терапія) передбачає введення досягнутої дози алергену щодня протягом 3-5 років. Схема другого етапу СЛАСІТ може змінюватися залежно від стану хворого. У випадку 
погіршення загального стану або появи симптомів алергії рекомендується знижувати нарощування дози алергену.

Підшкірна АCIT проводиться шляхом підшкірного введення розчину алергену у зростаючих дозах для кожного розведення. Стандартна схема парентеральної АСІТ неінфекційними алергенами представлена у додатку 9. Лікування здійснюється під контролем медичних працівників. Початкове дозування вибирають відповідно найменшому розведенню, яке дає негативний результат під час проведення шкірних проб у сенсибілізованих пацієнтів. Основний (ініціальний) курс лікування триває від 4 до 6 місяців (залежно від індивідуальних потреб пацієнта), після чого переходять на підтримуючу терапію алергенами протягом 3-5 років. Результати АСІT проявляються тривалим утриманням ремісії бронхіальної астми, запобігання трансформації легких варіантів захворювання у важкі, зменшенням обсягу базисного лікування.

Однак слід пам’ятати, що таке лікування не завжди є безпечним для хворого. Існують чіткі показаня і протипоказання до його використання, тому рішення про проведення такого лікування приймає виключно лікар - алерголог. I навіть за умови наявності чітких показань до АCIT ризик виникнення небажаних реакцій під час проведенні залишається, тому важливо розрізняти безпечну місцеву реакцію, реакцію шокового органу (бронхообструкція) та гострі загрозливі щодо життя стани (анафілактичний шок).

Місцеві реакції проявляються гіперемією на місці ін'єкції до 20 мм діаметром. Такі реакції для хворого безпечні, але потребують спостереження та фіксації часу, протягом якого вони зникнуть. Збільшення дози алергену призупиняється. Лікар повторює введення попереднього дозування до тих пір, поки не зникне місцева реакція, i лише тоді знову можна збільшувати дозування алергену. Якщо розвивається місцева реакція у вигляді міхура діаметром 20 мм і більше, вираженого набряку, свербіння, то дозу алергену зменшують, оскільки такі місцеві реакції свідчать про існування ризику появи системних реакцій.

Системні реакції виникають найчастіше до 30 хвилин після введення алергену (тому хворий повинен бути під наглядом лікаря не менше 30 хвилин). У випадку виникнення у хворого системної алергічної реакції з боку шокового органа ( прояви бронхообструкції) необхідно ввести в місце ін'єкції 0,1-0,2 мл (доза залежить від віку дитини) 0,1\% розчину адреналіну і таку ж кількість розчину у інше плече під шкіру. На плече вище місця ін’єкції накладають гумовий джгут. Для запобігання генералізованим реакціям, зокрема анафілактичного шоку, у кабінеті, де проводять АCIT, повинен бути відповідний набір протишокових засобів.

Найкращі результати АСІT реєструються за умови проведення тривалого лікування (3-5 років). 
Сьогодні АCIT широко використовується вітчизняними алергологами, однак, на жаль, ми не можемо бути цілком задоволеними традиційними алергенами. Чому? Бо існує двояка дія введеного алергену на організм, а саме : через клітину, яка презентує алерген, розвивається толеранція, а внаслідок підвищення $\operatorname{IgE}$ може розвинутися анафілаксія.

Чи можна усунути небажані ефекти? Мабуть, так, якщо б вдалося ввести у рекомбінантний алерген лише епітоп, що взаємодіє 3 Т-лімфоцитом. Алергени, які створюються в такий спосіб, називають рекомбінантними алергенами. Нині рекомбінантні алергени, які донедавна застосовувалися лише для наукових досліджень, вже починають приходити в клініку. 


\section{«Трудна» астма у дітей: особливості трактування та терапії}

Протягом останніх років майже щороку пропонуються нові узгоджувальні документи, схеми терапії бронхіальної астми, однак вирішити всі складності у практичному лікуванні пацієнтів не у всіх випадках вдається. Особливої уваги потребує група дітей, які недостатньо реагують на типове лікування, перебіг хвороби у них $є$ непередбачуваним. Такий варіант перебігу хвороби нерідко трактують як “трудну астму”. Нині описані різні варіанти так званої «трудної» бронхіальної астми. Їх трактування серед науковців і практиків в Україні і за іiі межами є далеко не однозначним. Така ситуація породжує невизначеність і розгубленість серед практичних лікарів. Наш досвід доводить, що термін «трудна астма» не зовсім вдалий з практичної точки зору й утруднює виділення групи дітей, яка потребує нашої чи не найбільшої уваги. Для виділення найбільш проблемної групи доцільно використовувати показники контролю бронхіальної астми. Неконтрольована бронхіальна астма часто асоціюється з “трудною", деякі автори навіть ставлять між ними знак рівності. Нам видається доцільним розмежувати ці поняття.

За відсутності контролю бронхіальної астми лікар, перш за все, повинен поставити собі запитання : Чи адекватною є базисна терапія? Якщо призначене лікування є правильним слід пошукати відповідь на таке питання : чи лікарські призначення виконуються в повному обсязі? Нині доведено i теорією i практикою, що в більшості пацієнтів застосування описаних класичних схем базисної терапії і добра співпраця між всіма учасниками лікувального процесу (лікарем, хворим і його родиною) дозволяють досягти контролю над бронхіальною астмою.

Однак, існує група дітей, які не реагують на типове лікування. Що робити в такій ситуації? На жаль, однозначної відповіді на ці питання сьогодні нема. Враховуючи досвід роботи 3 такими хворими, у Львівському міському дитячому алергологічному центрі розробили покроковий алгоритм лікарської тактики, який передбачає:

- $\quad$ Проведення повторної диференціальної діагностики. Може, це - не астма?

- Пошук супутньої патології (алергічний риносинусит, гастроезофагальний рефлюкс, імунодефіцит, атипова флора, гельмінтози, природжені вади розвитку серцево-судинної системи тощо).

Пошук додаткових, раніше неврахованих, тригерних чинників (алергени, вірусні інфекції, екологічні чинники, куріння, ліки тощо).

Особливо ретельно слід шукати супутню патологію. Зокрема, протягом 
останніх років активно вивчається роль мікоплазмової та хламідійної інфекцій у формуванні резистентного до терапії перебігу бронхіальної асми. Астма, асоційована 3 атиповою флорою, i перебігає важко, характеризується персистуючим перебігом на фоні адекватної терапії, важкими загостреннями 3 вираженими порушеннями вентиляційної функції легень. Саме такі діти повинні пройти специфічне обстеження. У разі позитивних тестів показаний 10денний курс лікування макролідами (кларитроміцин, азитроміцин). Виявлення Ig M до M.pneumoniae та Ig А до хламідій через місяць після закінчення курсу антибактеріальної терапії $\epsilon$ підставою для порторного 7-денного курсу лікування вказаними вище препаратами.

I, нарешті, бувають випадки, коли призначено оптимальне лікування і $€$ висока прихильність до лікування, однак астма не піддається контролю. Саме такі випадки (за різними даними вони складають від 2 до 5 \%) слід, на думку більшості авторів, трактувати як “трудну астму”. Вище відзначалося, що сьогодні не існує єдиного визначення поняття «трудної астми», дехто 3 практичних лікарів узагалі ставить знак рівності між важкою і трудною астмою, але, на щастя, далеко не кожний варіант важкої астми є “трудним”. Пацієнти 3 «трудною» астмою найбільшпроблемні, оскільки можливості лікаря в даному випадку $є$ обмеженими. Причини такої ситуації напевне треба шукати, аналізуючи генетичні маркери, що досить складно організувати, оскільки таких хворих небагато. Саме тому сьогодні актуально створення спеціального реєстру таких хворих в Україні 3 подальшою організацією проведення генетичних досліджень, які можливо дозволять знайти причини «трудної» астми. Такий шлях абсолютно реальний сьогодні. Потрібні лише бажання й ентузіазм зацікавлених сторін. Однак уже нині лікарі працюють 3 такими пацієнтами вже сьогодні і потрібний конкретний алгоритм дій. Що можемо зробити:

\section{- $\quad$ Оптимізувати базисне лікування.}

- $\quad$ Забезпечити домашню аптечку для невідкладної допомоги ( системні кортикостероїди, небулайзер з набором бронхолітичних препаратів та ІГКС для інгаляційного введення).

\footnotetext{
- Забезпечити щоденну пікфлоуметрію i ведення щоденника самоспостереження.
}

- Забезпечити постійні контроль і зв'язок з лікуючим лікарем (повинен бути один лікар!).

Особливі труднощі виникають під час вибору оптимальної базисної терапії для таких пацієнтів. Згідно визначення робочої групи експертів Європейського респіраторного товариства (ERS), бронхіальна астма у дітей вважається «трудною», якщо вона недостатньо контролюється призначенням беклометазону в дозі більше 800 мкг/добу чи еквівалентної дози іншого ІКС. Іноді лікарі просто втомлюються підбирати лікування, видається, що зроблені 
спроби є безрезультатними, але ми не маємо права припиняти пошук оптимальної базисної схеми. Така дитина мусить отримувати ГКС. I в даному випадку найбільша проблема - підбір адекватного дозування. Ми маємо пам'ятати, що у разі потреби дитина може отримувати добову дозу ІКС до 800 мкг беклометазону дипропіонату чи еквівалентної дози іншого ІКС. Запитаймо себе: Чи призначаємо ми такі дози? Водночас існують дослідження взаємозв’язку “доза-відповідь” у разі застосування IКС, які продемонстрували значне зниження ефекту, якщо дози перевищують 800 мкг/день для будесоніду i 400 мкг/день для флютиказону пропіонату. Немає переконливих даних, які 6 підтверджували велику ефективність вищих доз ІГКС, хоча в окремих пацієнтів можна очікувати ефекту. У випадку “трудної” астми показана комбінована терапія, яка передбачає поєднання високих доз IKC із пролонгованими $\beta_{2^{-}}$ агоністами, антилейкотрієновими препаратами, повторними курсами антибіотиків-макролідів. Протягом останніх років на фармацевтичний ринок України вийшов новий препарат Омалізумаб, який належить до принципово нового класу i являє собою рекомбінантні гуманізовані моноклональні антитіла, які вибірково зв'язуються з циркулюючими IgЕ. Існують дані, що цей препарат дозволяє вирішити проблему «трудної» астми в окремих пацієнтів, коли доведений атопічний генез захворювання.

Окремі автори вважають, що у випадках «трудної» астми доцільно застосовувати системні стероїди i препарати зі стероїд-спаринг ефектом (метотрексат, циклоспорин А тощо). I лише в поодиноких випадках, у разі доведення відсутності чутливості до кортикостероїдів, їх застосування $\epsilon$ недоцільним (у педіатричній практиці таких хворих практично немає).

Деякі автори рекомендують замісну терапію 3 уведенням імуноглобулінів та антитіл до імуноглобуліну Е.

У разі загострення захворювання дитина 3 «трудною» астмою мусить бути одразу ж госпіталізована у спеціалізований стаціонар, де працюють фахівці, які зуміють швидко організувати надання оптимальної невідкладної допомоги. Така дитина повинна перебувати у стаціонарі разом з мамою. Мама, i тільки вона, є джерелом спокою, основною опорою i особою, якій дитина довіряє найбільше. Тільки мама здатна створити навколо дитини ауру, яка сприяє найшвидшому одужанню. Адекватна терапія, сприятливе оточення запорука успіху в лікуванні загострення “трудної” астми у дітей. 


\section{Історичний екскурс - GINA 1995-2017 роки}

У 1993 році була створена творча група з вивчення всесвітньої проблеми розвитку бронхіальної астми під керівництвом Всесвітньої організації охорони здоров'я та Інституту серця, легенів і крові США. Діяльність команди привела до публікації доповіді про можливості терапії і профілактики бронхіальної астми. В подальшому виникла організація GINA (Global Strategy for Asthma Management and Prevention - Глобальна стратегія з управління та профілактики бронхіальної астми), що представляє собою структуру, яка об'єднує мережу організацій громадського здоров'я та медичних товариств, лікарів і вчених, експертів даної галузі з усього світу. Метою об'єднання стала розробка правил діагностики, лікування та профілактики бронхіальної астми, а також інформування пацієнтів і населення загалом. За щорічними звітами Асамблеї, що відображають новітні тенденції в менеджменті хворих на бронхіальну астму, стежать лікарі та вчені всього світу.

Перший рапорт експертів був опублікований у 1995 році під назвою «Глобальна стратегія управління астмою та профілактика» $\mathrm{i}$ широко прийнятий медичною громадськістю і суспільством. Починаючи 32002 року рапорти щороку актуалізуються, опираючись на найновіші наукові дані. До сьогодні постійне оновлення цього документу стає є основою для керівних принципів щодо астми в багатьох країнах світу, зокрема в Україні. 3 моменту свого створення GINA зазнала ряд змін у парадигмі. Першою була зміна, яка стосувалася управління важкістю астми - був впроваджений підхід, заснований на доказах, а не тільки на думках і досвіді експертів. Наступною, ще більш радикальною зміною був перегляд у 2006 році керівних принципів GINA, які стосувалися включення у класифікацію астми поняття контролю. До принципів контролю над астмою були введені такі елементи: важливість партнерства між пацієнтом і медичним персоналом, навчання пацієнта та керовані (чітко прописані) цілі лікування.

Істотні зміни стосовно клінічного підходу до терапії астми у формі суттєвої ревізії рекомендацій опубліковані у 2014 році, коли метою лікування астми було прийнято не лише досягнення контролю хвороби, але й вчасну редукцію майбутніх ризиків загострення. Рапорт GINA 2014 також впровадив поняття персоніфікованої терапії астми і наголосив на потребу пошуку індивідуального підходу до лікування у кожного пацієнта.

Від часу ревізії узгоджувального документу у 2014 році запропонована нова дефініція бронхіальної астми, яка підкреслює гетерогенність даного захворювання й існування різних фенотипів астми.

Останні версії GINA не несуть революційних змін в опіці над пацієнтом, хворим на бронхіальну астму. Однак варто обговорити їх, щоб актуалізувати 
знання з діагностики і лікування даної патології. У 2017 році суттєві зміни у рапорті внесені в розділі, присвяченому співіснуванню бронхіальної астми і ХОЗЛ. Перший раз експерти присвятили цій проблемі цілий розділ ще у 2014 році. Гірший прогноз таких пацієнтів і практична відсутність клінічних досліджень, які б вивчали ефективність у них різних схем лікування стали підставою для поглибленої спільної роботи експертів GINA та GOLD (Global Initiative for Chronic Obstructive Lung Disease). Важливим і своєчасним став програмний документ “Diagnosis and initial treatment of Asthma, COPD and Asthma-COPD Overlap” виданий у 2017 році об’єднаними зусиллями експертів GINA та GOLD. Документ окреслює основні ключові положення щодо ведення пацієнтів за неможливості до кінця уточнити діагноз, що особливо важливо для сімейного лікаря (терапевта) первинної ланки. Здебільшого це оновлення внесло уточнення щодо терміну «Asthma-COPD Overlap» (АстмаХОЗЛ Перехрест). Ключові положення пояснюють, що так званий перехрест $\epsilon$ коморбідним станом, а не окремим синдромом. Важливість документу в тому, що він дозволяє клініцистам (особливо на первинній ланці) мати інформацію щодо ведення пацієнтів з коморбідністю бронхіальної астми та ХОЗЛ, а не шукати компроміс з двох окремих рекомендацій. Крім того, термін «AsthmaCOPD Overlap» буде спонукати науковців до уточнення механізмів розвитку такої комбінації та вдосконалення методів лікування.

Крім складання керівних принципів і звітів щодо лікування астми, GINA бере активну участь в організації та координації Всесвітнього дня боротьби 3 астмою, регіональних ініціатив і симпозіумів GINA. В цілому, упродовж всіх років з моменту першого видання в 1995 році, керівні принципи GINA стали основою багатьох національних стратегій астми у всьому світі. Цей курс, найймовірніше, буде продовжуватись і надалі. 


\section{ПРИХИЛЬНІСТЬ ДО ЛІКУВАННЯ ТА НАВЧАННЯ ПАЦІЕНТІВ}

Довгострокова мета терапії бронхіальної астми полягає у досягненні контролю симптомів, підтримці нормального рівня активності пацієнта, а також в мінімізації ризику загострень і побічних ефектів медикаментів. Відповідно до результатів міжнародних досліджень частка пацієнтів 3 контрольованим перебігом бронхіальної астми виросла з 5\% у 1999 р до 55\% у 2014 р. Позитивна тенденція пояснюється впровадженням в клінічну практику стратегії щодо базисної терапії за допомогою ІКС, антилейкотрієнових препаратів, $\beta 2$ агоністів тривалої дії та їх комбінацій. Водночас, в нашій країні суттєвим $€$ відсоток хворих з неконтрольованим перебігом бронхіальної астми, високим ризиком загострень, госпіталізацій та низькою якістю життя. Для вирішення цісї проблеми окрім досягнень фармакотерапії та вартості ліків величезне значення має прихильність хворих до лікування.

Науково обгрунтована методологія ведення пацієнта стосовно всіх хронічних захворювань була започаткована наприкінці $70-x$ років минулого століття. Поступово сформувалася термінологія, яка характеризує рівень співпраці між лікаре і пацієнтом, а саме виділені поняття:

- Concordance: пацієнт та лікар прийшли до згоди що до найбільш прийнятної терапії захворювання. Пацієнт повністю розуміє режим терапії.

- Compliance: пацієнт має бажання слідувати призначеному курсу терапії.

- Persistency: пацієнт приймає ліки впродовж усього періоду терапії, згідно до призначень лікаря.

У 2003 році матеріали щодо методології ведення пацієнта за участі самого пацієнта були систематизовані в документі «World Health Organization. 2003. Adherence to long-term therapies. Evidence for action. Geneva: World Health Organization», після чого найбільш прийнятним визнаний термін adherence (прихильність), який поєднує розуміння, бажання та активну дію пацієнта (compliance \& persistency). Згідно з визначенням експертів ВООЗ, прихильність до лікування - це поняття, яке характеризує, наскільки точно та послідовно пацієнт виконує надані лікарем рекомендації. Іншими словами, прихильність це ступінь відповідності поведінки пацієнта рекомендаціям, наданим лікарем, при цьому особливу увагу приділяють питанню активної участі пацієнта у процесі лікування .

Прихильність дозволяє оцінити кількість доз медикаментів, які дійсно були отримані пацієнтом за визначений проміжок часу (курсове, або тривале лікування), за якою схемою та в які періоди доби приймалися всі виписані ліки. «Золотого стандарту» для оцінки прихильності до лікування не існує. Використовуються фармакологічні, клінічні, фізичні методи оцінки 
прихильності, а також спеціально розроблені опитувальники i шкали. Прикладом валідованого тесту оцінки прихильності пацієнтів до лікування $є$ опитувальник D.Morisky. За цією шкалою оцінка прихильності пацієнтів до лікування проводиться понад 20 років останніх років, причому для різних хронічних захворювань застосовуються різні модифікації іiі. Найчастіше в клінічній практиці прихильність щодо лікарської терапї визначається як вживання, принаймні, 80\% фармпрепарату від належного (в ідеалі 100\%). Важливо зазначити, що особливого значення прихильність до лікування набуває на амбулаторному етапі, адже в стаціонарних умовах досягти їі значно легше.

Фактори впливу на прихильність пацієнтів до лікування поділяються на три великі групи:

- залежні від режиму і методів лікування (пов'язані з лікарем);

- залежні від фізичного та психологічного статусу пацієнта;

- залежні від медико-соціальної підтримки (організація охорони здоров’я).

Прихильність до терапії визначається поєднанням об'єктивних і суб'сктивних показників iï клінічної ефективності. Аналіз літературних джерел, що стосуються вивчення прихильності до лікування багатьох хронічних захворювань, дозволив виділити ключові моменти, які впливають на прихильність, а саме:

1. Клінічна ефективність основних класів лікарських препаратів та їх комбінацій, покращання якості життя пацієнта.

2. Безпека основних класів лікарських препаратів та їх комбінацій.

3. Багаторазовий прийом, технічні складності і незрозумілі рекомендації.

4. Освітній рівень і стан пацієнта (депресії), підтримка родичів і друзів.

5. Рівень медико-соціальної підтримки (ціна препарату i можливість компенсації)

Неприхильність до лікування - не усвідомлене рішення, прийняте пацієнтом в результаті власного аналізу витрат / вигод, оцінки співвідношення (вартість + ризик) / користь втручання на підставі власних уявлень і доступної інформації. Найбільша складність виникає у разі комплексного лікування пацієнтів 3 коморбідними станами. Здебільшого це хворі похилого віку 3 поєднаною пульмонологічною та серцево-судинною патологією. Погану прихильність до лікування демонструють пацієнти у разі потреби багаторазового прийому ліків. Так у разі 4 разового режиму прийому препаратів пацієнти отримують менше ніж 70\% від запропонованої дози, а при 5-разового менш ніж 60\% . Недостатнє використання ліків спостерігається значно частіше ніж надмірне. Тому одним із завдань на шляху вирішення проблеми підвищення прихильності до лікування $\epsilon$ створення різних форм комбінованих препаратів $з$ простими режимами дозування. 
Освітній рівень пацієнтів відіграє досить важливу роль щодо прихильності, однак здебільшого хворі змінюють своє ставлення до терапії на підставі погіршення самопочуття.

Рівень задоволення пацієнтів під час отримання інформації безпосередньо від лікаря багато в чому залежить від контакту між лікарем і пацієнтом, і від того, як цей контакт сприймається пацієнтом. Проведений у 2007 році метааналіз показав, що об'сктивна важкість стану паціснтів та їх поінформованість про свій стан є предикторами прихильності. Однак у разі вираженої депресії, пацієнти 3 найважчим станом можуть мати найменшу прихильність до лікування.

У депресивних пацієнтів у три рази збільшується неприхильність до схем лікування, фізичних вправ, дієти, поведінки щодо здорового способу життя та інших призначень лікаря.

Прихильність до терапії зростає у пацієнтів у разі довіри до лікаря, якщо схема лікування є ефективною за об'єктивними та суб'єктивними показниками, а побічні дії не перевищують ефект від призначеного лікування Глобальна оцінка якості життя пацієнта 3 хронічним захворюванням визначається контролем симптомів, незалежністю від медико-соціальних служб, зручністю прийому препаратів і використання пристроїв у повсякденному житті та відсутністю побічної дії препаратів.

Низька прихильність досить часто спостерігається незалежно від віку, статі, освітнього та соціально-економічного статусу пацієнта, виду захворювання та важкості стану і в кожному конкретному випадку потребує ретельного вивчення. Важливо пам'ятати, що у разі тривалого лікування хронічних захворювань прихильність пацієнтів знижується з часом, особливо коли соціальне оточення не підтримує хворого у повсякденному житті.

Свого роду переломним моментом для сімейних лікарів стала публікація GINA-2014, яка на відміну від колишніх варіантів, є довідником для реальної клінічної практики, заснованим на принципах доказової медицини та стандартизованих результатах лікування і профілактики бронхіальної астми. У підсумковому документі наведені рекомендації щодо проведення регулярної динамічної оцінки ефективності терапії бронхіальної астми, яка, окрім показників контролю симптомів за останні 4 тижні та виявлення факторів ризику несприятливого прогнозу бронхіальної астми, включає в себе перевірку техніки інгаляції та прихильності до лікування, виявлення побічної дії препаратів, складання письмового плану дій для пацієнта після з'ясування його уподобань в лікуванні бронхіальної астми .

Недостатня прихильність до призначеного лікування та неправильна техніка інгаляції $\epsilon$ основними причинами незадовільного контролю бронхіальної астми. Серед причин поганої прихильності хворих до фармакотерапії бронхіальної астми можна виділити основні: 
- $\quad$ пацієнти не вважають базисне лікування потрібним( від 45 до 55\% у різних дослідженнях);

- складність виконання режиму призначеної терапії (потреба прийому різних препаратів кілька разів на день);

- $\quad$ труднощі, пов'язані із методикою використання інгаляційного пристрою.

Аналіз літератури та власний досвід дозволяють систематизувати негативні впливи на прихильність до лікування хворих на бронхіальну астму таким чином:

1) медикаментозні:

- труднощі у використанні інгалятора (призначати інгалятори можна тільки після того, як пацієнти пройшли навчання з використання пристрою $\mathbf{i}$ продемонстрували задовільну техніку);

- незручний режим фармакотерапії (4 рази в день, багато препаратів);

- побічні дії;

- вартість препаратів;

- перебої з постачанням необхідних медикаментів на фармацевтичний ринок;

2) немедикаментозні:

- незрозумілий або недостатній інструктаж;

- страх перед побічними діями;

- відсутність контакту і невдоволення медичним персоналом;

- невизначений страх або занепокоєння;

- невиправдані надії як зі сторони пацієнта, так і з боку лікаря;

- недостатнє спостереження за пацієнтом, відсутність якісного моніторингу ;

- роздратованість (депресивний стан) з приводу свого стану або якості лікування;

- недооцінка важкості стану, забудькуватість, невиправданий спокій;

- культурні традиції;

- особлива позиція щодо свого здоров'я (асоціальні особи).

У клінічній настанові з бронхіальної астми (2009 рік) з позицій доказової медицини було показано, що письмові індивідуальні плани дій в рамках навчання $з$ самоконтролю поліпшують показники здоров'я пацієнтів 3 астмою. Високого ступеня доказовості $($ А,Б) в цьому питанні було досягнуто у пацієнтів з недавно перенесеними загостреннями помірної та важкій БА на вторинному рівні медичної допомоги. Успішні втручання скоротили кількість випадків госпіталізації і звернень до відділень невідкладної допомоги людей 3 важкою астмою.

У багатьох дослідженнях було зроблено висновок щодо покращення результатів лікування пацієнтів завдяки таким якостям як впевненість у власних силах, знання і довіра. Доведено, що пацієнтам з астмою необхідно запропонувати навчання 3 самоконтролю, зосереджене на індивідуальних потребах і підкріплене письмовим індивідуальним планом лікування. Такий 
план, розроблений висококваліфікованими клініцистами, пацієнти повинні одержати перед випискою з лікарні.

Виходячи з цієї позиції, протягом останніх років у практичну роботу лікарів впроваджуються різнопланові освітні програми для пацієнтів та їхніх родин. Однак незважаючи на багаторічний досвід їх застосування і постійне вдосконалення, ряд аспектів освітньої роботи 3 пацієнтами залишаються дискутабельними. Зокрема, і досі триває активна дискусія щодо переваг двох основних форм навчання - індивідуальної та групової. Більшість практичних лікарів схиляються до проведення індивідуальних занять.

Львівський міський дитячий алергологічний центр один із перших в Україні впровадив у свою практичну роботу навчальні програми для пацієнтів, хворих на бронхіальну астму. Це дозволяє нам сьогодні робити обгрунтовані висновки і рекомендації.

Навчання хворого - це тривалий процес, основною ланкою якого $є$ самоконтроль. Для грамотного його здійснення обов'язковими є такі елементи:

- поінформованість пацієнта (система впливу медичних працівників, найбільш ефективною $\epsilon$ спільна робота групи, що складається 3 лікаря, медичної сестри та фармацевта );

- достовірний вимір показників видиху (об’єктивізація стану пацієнта за допомогою пікфлоуметрії);

- зрозумілі для пацієнта i абсолютно конкретні інструкції, щодо алгоритму дій на початку нападу;

- гнучкі і тривалі контакти лікаря, медичної сестри і пацієнта (прописана система моніторингу - графіки прийому, щоденники пацієнта).

Для полегшення самоконтролю за лікуванням може бути використана спеціальна система оцінки об'єктивного стану пацієнта за допомогою пікфлоуметра - принцип світлофора. Вона була запропонована у 90-х роках минулого століття, але не втратила актуальності і сьогодні. Три кольори (зелений, жовтий і червоний) на шкалі пікфлоуметра позначають відповідний стан хворого. Кожному кольору відповідає так звана "зона" з відповідними симптомами захворювання.

- "Зелена зона" означає, що астма перебуває під контролем. Сон, фізична активність не порушені, симптоми захворювання мінімальні або відсутні. Показники пікової об'ємної швидкості видиху складають 80-100 від належних, а добові коливання не перевищують 20\%. Хворий отримує ефективну планову терапію, призначену лікарем. Якщо стан хворого відповідає "зеленій зоні" протягом не менше ніж три місяці, лікарю слід розглянути можливість обережного зменшення медикаментозного навантаження ("сходинка вниз".

- Жовта зона" означає "Увага". Вона характеризується появою кашлю, свистячого дихання або нападів задишки на тлі нормальної фізичної активності, показники пікової об'ємної швидкості видиху в межах 60-80\% від 
належних, а добові коливання показників не перевищують 30\%. Необхідно порадитися з лікарем, адже перехід у "жовту зону" означає не зовсім успішний контроль астми на тлі терапії, що проводиться ( зателефонувати лікарю).

- $\quad$ "Червона зона" - сигнал тривоги. Симптоми астми присутні як при мінімального фізичного навантаженні так і в спокої. Значення пікової об'ємної швидкості видиху становить 60\% - нижче від належних або найкращих індивідуальних показників. Необхідно застосувати $\beta 2$-агоністи короткої дії i, якщо після їх використання показники пікової об'ємної швидкості видиху залишаються менше $60 \%$, терміново звернутися до лікаря (огляд спеціаліста або швидка медична допомога).

Хворим рекомендується вести щоденник самоконтролю 3 реєстрацією ранкових і вечірніх показників пікфлоуметрії. Відповідно до зони лікуючий лікар розробляє план лікування, враховуючи індивідуальні особливості хворого і варіант перебігу захворювання .

Прихильність до лікування бронхіальної астми нерозривно пов'язана 3 навичками щодо ефективного використання інгаляційних пристроїв. У підсумковому документі GINA 2016 вказано, що більшість пацієнтів (до 80\%) не може або не вміє правильно використовувати інгалятор. Для подолання цієї проблеми лікарю пропонується виконувати правило 4С:

- Choose Вибрати найбільш зручний для пацієнта пристрій. В ідеалі всі інгаляційні ліки добре було б подавати через один варіант пристрою.

- Check Перевірити техніку виконання інгаляції при кожному зручному випадку. Просити пацієнта, щоб він показував як саме він використовує інгалятор.

- Correct Під час практичної демонстрації, звернути увагу на неправильні кроки. Перевірити техніку повторно, до 2-3 разів, якщо це необхідно.

- Confirm Переконатися, що у пацієнта $\epsilon$ інструкції до кожного 3 призначених інгаляторів, він може продемонструвати правильну техніку в кожному окремому випадку.

Інформацію про інгаляційні пристрої та методику їх використання можна знайти на веб-сайті GINA (www.ginasthma.org) та веб-сайті ADMIT (www.admit-inhalers.org).

Як перевірити і поліпшити прихильність до лікування? Близько 50\% дорослих і дітей з бронхіальною астмою, не виконують інструкцій. Не залежно від того як це відбувається - навмисно (не сприймається необхідність лікування, існує страх щодо побічних ефектів, не влаштовує вартість) чи ненавмисно (забудькуватість, незрозумілі інструкції) лікарю потрібно виявити максимальну привітність та обговорити це з пацієнтом. Для отримання правдивої відповіді запитання потрібно ставити в такий спосіб, щоб стимулювати пацієнта на відвертість. Наприклад, запитували так: “Я знаю наскільки складно приймати ліки регулярно. Чи забуваєте Ви інколи прийняти призначені Вам ліки?” Така 
форма звернення до пацієнта дозволяла нам отримувати правдиву відповідь. Перевірте використання ліків, що відпускаються за рецептом 3 часу при відповідно до лічильника доз або записів у щоденнику. Розпитайте про ставлення пацієнта до ліків та і уявлення про астму як таку.

Крім того у GINA 2014 звертається увага на те, що на кожному етапі перед прийняттям рішення про збільшення обсягу терапії обов'язковою є перевірка техніки інгаляції та прихильності до лікування.

Таким чином у практичній діяльності лікаря спільного 3 пацієнтом вирішення потребують такі питання:

- прийняття рішення щодо лікування і вибору дози;

- чи $є$ в інгаляторі пристрій для нагадування про пропущені дози (лічильник доз);

- зниження складності режиму лікування (один раз або двічі на день);

- комплексне навчання щодо астми з домашніми візитами спеціально навчених медсестер ( маленькі діти, люди похилого віку);

- зворотний зв'язок щодо виконання призначень лікаря (анкетування, самооцінка), моніторинг.

Індивідуальна робота 3 пацієнтами дуже важлива, однак, вона повинна доповнюватися іншими формами і методами навчання хворих. Протягом останніх років у різних країнах створюються спеціальні навчальні програми для хворих на бронхіальну астму. Поінформованість пацієнта та оволодіння навичками самоконтролю допомагає хворим зрозуміти суть захворювання i пов'язану з нею потребу тривалого лікування.

До колективних форм навчання пацієнтів відносять астма-школи та астма-клуби. Ініціатива організації астма-шкіл належить медичним працівникам, тому активність хворих або їх батьків прямо залежить від довіри до лікаря .

Більш відкритими структурами, що створюються за ініціативою самих пацієнтів, є астма-клуби. Вони передбачають не тільки постійні цілорічні заняття, але і неформальне спілкування пацієнтів між собою. Це громадські організації, що проводять роботу з групами хворих різного віку та важкості захворювання. В рамках астма-клубу можуть існувати різні астма-школи. Приблизний план занять такого клубу :

1. Основні причини бронхіальної астми. Поняття про алергію.

2. Механізми розвитку бронхіальної астми.

3. Способи діагностики та контролю бронхіальної астми. Пікфлоуметрія.

4. Принципи лікування бронхіальної астми. Правила інгаляційної терапії.

5. Лікування хронічного запалення у разі загострення бронхіальної астми. Протирецидивне лікування.

6. Як поводитися під час загострення бронхіальної астми. Питання і відповіді.

7. Психотерапія дітей з бронхіальною астмою. 
8. Спосіб життя хворих на бронхіальну астму (харчування, режим дня, фізична активність тощо).

9. Дихальна гімнастика, лікувальна фізкультура при бронхіальній астмі. Санаторно-курортне лікування.

Кількісна оцінка доброго навчання хворого та його адекватного самоконтролю має медичну i економічну сторони i виражається такою комплексною характеристикою, як кількість здорових днів, проведених:

- без лікарняного листа;

- без госпіталізацій;

- без амбулаторного візиту до лікаря;

- без застосування курсу оральних антибіотиків;

- без призначення курсу оральних кортикостероїдів.

До втрати контролю та загрози життю пацієнта може призвести: формальний характер динамічного спостереження за хворим, відсутність у пацієнтів усвідомленого підходу до лікування та профілактики загострень, неправильний стереотип дій пацієнтів під час нападу. Виходячи з цього, можна сформулювати положення, які відіграють головну роль у навчанні пацієнта:

1. Хороший психологічний контакт лікаря, медсестри і пацієнта.

2. Забезпечення пацієнта та його сім'ї кваліфікованою інформацією про захворювання (бесіда, інформаційні листи, популярні розробки, написані зрозумілою мовою, розміщення інформації на сайті установи, можливий інтерактив).

3. Охоплення навчальними заходами (астма-школа, бесіди, відео-фільми, робота спеціальних асоціацій тощо).

4. Наявність індивідуального письмового плану лікування пацієнта та його моніторинг (дозування базисних препаратів при відповідних показниках пікфлоуметра, показання до застосування бронхолітиків, правила ведення щоденника самоконтролю тощо).

Аналіз застосування різних стратегій щодо підвищення прихильності хворих до лікування бронхіальної астми дозволяє стверджувати, що найефективнішими є такі моменти :

- спільне прийняття рішення;

- спрощення режиму лікування (прийом препарата1 раз на день замість 2 разів);

• комплексне навчання пацієнта під час домашніх візитів медсестри;

• використання вбудованого в інгалятор пристрої нагадування;

• контроль щоденника пацієнта.

Найбільш реальними для звичайної клінічної практики можуть бути дві перші стратегії. Спільне прийняття рішення щодо лікування передбачає усвідомлену згоду пацієнта з терапією, що проводиться, йогоактивну участь у лікувальному процесі. Більш універсальною $є$ друга стратегія (спрощення 
режиму лікування), яка може бути застосована у всіх хворих 3 низькою прихильністю до лікування і ефективність якої була доведена в багатьох клінічних дослідженнях. На жаль в нашій країні немає спеціальної служби патронажних сестер, які самостійно і регулярно відвідують хронічних хворих. Ведення щоденника - дуже корисний метод, але для цього потрібен пікфлоуметр та бажання і ретельність пацієнта. Інформування та навчання пацієнта, партнерські стосунки з хворим в процесі лікування, а також простий режим терапії (інгалятор 1 раз на день) є запорукою оптимальної прихильності до лікування при БА. 


\section{БРОНХІАЛЬНА АСТМА : АНАЛІЗ ДІАГНОСТИЧНИХ І ТАКТИЧНИХ ПОМИЛОК}

Історія медицини - це не лише історія великих досягнень, але й багатьох, нерідко непоправних помилок. Помиляються всі лікарі, навіть найкращі, найдосвідченіші. Більше того, справедливими є слова відомого академіка, патологоанатома 3 50-річним стажем І.В. Давидовського, який неодноразово повторював, що число діагностичних помилок збільшується із підвищенням кваліфікації лікаря. Безперечно, це значною мірою пояснюється тим, що висококваліфіковані лікарі частіше мають справу 3 особливо складними для діагностики і лікування випадками.

Підставою для фахових дій лікаря $є$ діагноз, тобто точне розпізнавання хвороби. Сьогодні завдяки автоматизації i механізації діагностичних досліджень розширились їх можливості і підвищилася точність. Незважаючи на це, діагностичні помилки реєструються досить часто, цій проблемі присвячено багато праць, вона активно обговорюється на серйозних лікарських форумах. Більше того, сьогодні існують навіть різні варіанти класифікації діагностичних помилок. На наш погляд, дуже вдалим $є$ розподіл причин діагностичних помилок, запропонований швейцарським терапевтом Р. Геглліном, який вважає найважливішими 3 них такі: незнання, недостатнє обстеження хворого, аналітичні помилки, помилки технічного характеру, переоцінка результатів інструментальних методів дослідження.

Про переоцінку результатів інструментальних методів дослідження як одну з найбільших помилок сучасної медицини неодноразово говорить у своїй чудовій книзі «Утерянное искусство врачевания» видатний кардіолог Бернард Лоун.

Сьогодні, говорячи про лікарські помилки, мусимо визнати, що вони нерідко пояснюються зміною патоморфозу захворювань. Алергічні захворювання у XXI столітті за багатьма клінічними параметрами суттєво відрізняються від тих, з якими мали справу лікарі ще навіть 10-20 років тому. Для того, щоб не розгубитися в такій мінливій ситуації, треба багато читати, думати, аналізувати, використовуючи всі доступні джерела інформації. Протягом останніх років на сторінках спеціальної літератури ми все частіше бачимо посилання на досвід наших закордонних колег. Все більше практичних лікарів застосовують у своїй роботі західний стиль медицини. Чи це погано? Однозначної відповіді на це питання сьогодні не має. Але, як гадаємо, наша медична школа також має прекрасні традиції. Тому в своїй практичній i науковій діяльності нам, напевне, треба керуватися геніальними настановами Т.Г. Шевченка : «І чужому научайтесь, й свого не цурайтесь».

Сучасний рівень медичних знань дозволяє ефективно лікувати бронхіальну астму вже на ранніх стадіях іiі виникнення. Більше того, розширюються можливості іi профілактики. Водночас все це підвищує відповідальність лікаря за своєчасність і правильність встановлення діагнозу. 
На думку талановитого клініциста академіка В. Н. Виноградова, більшість помилок допускається на амбулаторному етапі, коли лікар самостійно вирішує питання первинної діагностики. У дорослих пацієнтів переважно спостерігається типовий клінічний перебіг бронхіальної астми 3 розвитком напад ядухи. I в цьому контексті вдалим видається вислів відомого польського професора Вацлава Дроща : "Бронхіальна астма як кохання : ніхто не знає, що це таке, але кожен ії впізнає, коли вона прийде” .

Водночас ситуація $з$ дитячою астмою $є$ складнішою. Бронхіальна астма у дітей перших п'яти років життя 3 багатьох причин залишається однією 3 найтрудніших проблем педіатрії. Нерідко першим ії тривожним дзвіночком $\epsilon$ рецидивний бронхообструктивний синдром, у трактуванні якого часто допускаються діагностичні помилки. Чому так часто помиляються лікарі? Перш за все тому, що донині не існує єдиних підходів до трактування цього синдрому в педіатрії, залишаються до кінця не розробленими критерії диференціальної діагностики цілого ряду респіраторних захворювань, які перебігають 3 симптомами бронхіальної обструкції. Така ситуація нерідко зумовлює гіподіагностику астми у дітей, коли іiі ховають за такими, часто неіснуючими, діагнозами як :

- Обструктивний бронхіт, рецидивний перебіг

- Хронічний бронхіт з астматичним компонентом

- Рецидивний бронхіт

- Пневмонія з бронхообструктивним синдромом Треба визнати, що трапляються і випадки гіпердіагностика астми у дітей, коли за цим діагнозом ховаються :

- Сторонне тіло трахеї, бронхів

- Глистяна інвазія

- Муковісцидоз

В такій ситуації особливо гострим видається питання : Коли діагностувати і коли починати терапію астми? Сьогодні немає єдиного рецепту щодо алгоритму дій лікаря у разі рецидивного бронхообструктивного синдрому у дітей раннього віку, не існує специфічних маркерів для діагностики астми в цей віковий період. Потрібні тривале спостереження і ретельна диференціальна діагностика. Водночас існують критерії, які дозволяють лікарю подумати про наявність у дитини бронхіальної астми, а саме:

- атопічний анамнез ( збільшує вірогідність бронхіальної астми, але не $є$ абсолютно необхідним для її діагностики);

- періодичність виникнення симптомів : три епізоди бронхообструкції протягом 1 року (ядуха, свистяче дихання, нападоподібний кашель) із задокументованим покращенням після застосування $\beta_{2}$-агоністів короткої дії;

— один, але важкий епізод бронхообструктивного синдрому, який вимагав госпіталізації і застосування системних кортикостероїдів; 
- виникнення загострень, спровокованих не лише вірусною інфекцією, а й дією алергенів чи фізичним навантаженням.

Трудною в діагностичному плані i найчастішою $\epsilon$ проблема дифдіагностики бронхіальної астми 3 бронхообструктивним синдромом, спровокованим інфекцією. Прояви бронхообструкції, які розвиваються виключно на фоні інфекції не виключають наявність бронхіальної астми, але вірогідність діагнозу $є$ вищою, якщо бронхообструктивний синдром спостерігається і поза епізодами інфекції.

Загалом симптоми астми не $є$ специфічними, тому треба завжди виключати інші причини бронхообструктивного синдрому. Однак, коли вірогідність бронхіальної астми $є$ високою, рекомендоване призначення пробної базисної терапії, ефективність якої підтверджує діагноз. Правильне розуміння ролі пробної терапії бронхіальної астми у дітей $є$ надзвичайно важливим для педіатрів і сімейних лікарів. Пробна терапія - задокументована можливість лікаря підтвердити діагноз астми у дітей з високим ризиком іiі розвитку. Оцінювати результати пробного лікування потрібно протягом 3-х місяців, однак у реальній практиці часто не витримуються вказані вище терміни призначення базисного лікування. Слід відзначити, що пробне лікування дозволяє не лише ефективно лікувати хворобу, але й сприяє своєчасному встановленню діагнозу бронхіальної астми у дітей.

Реалії сьогодення показуть, що у близько 40\% дітей бронхіальна астма має легкий інтермітуючий перебіг, що завжди є причиною лікарських сумнівів - астма це чи ні. Більше того, сьогодні існують дві стратегії лікування інтермітуючої астми : терапія на потребу і тривала базисна терапія. Лікарі стоять перед питанням : Яку стратегію обрати? Сдиного рецепту на сьогоднішній день немає, і в таких випадках ми мусимо слухати свою інтуіцію.

На жаль, навіть за умови вчасної діагностики бронхіальної астми і правильного призначення терапевтичного комплексу, пацієнти нерідко допускають помилки, пов'язані з порушенням інгаляційної техніки, що не дозволяє досягти успіхів в лікуванні. Відомо, що ефективність інгаляційного лікування забезпечують якість ліку, пристрій, що забезпечує подачу ліку, легкість обслуговування пристрою i легкість інгалювання (незначний опір інгалюванню). Треба пам'ятати, що на сьогоднішній день не існує найкращого способу проведення інгаляції, немає ідеального інгалятора, однак існують широкі можливості для вибору ліку i шляху його введення. Лікар повине рекомендувати, але лише пацієнт вибирає найзручніший для себе спосіб інгалювання, адже навіть найкращий пристрій не дозволить досягти ефекту, якщо інгаляція не буде правильно проведена. В педіатричній практиці особливо привабливим виглядає введення ліків щляхом небулізації, однак іноді плач, крик, неспокій дитини дозволяють констатувати несприйняття небулізації i диктують потребу пошуку альтернативної подачі ліків ( дозований аерозоль через спеціальний спейсер).

Призначаючи лікування, треба обов'язково поінформувати пацієнта про його безпеку, адже хворі бояться тривалого лікування. Особливо це стосується 
стероїдофобії. Більше того, сьогодні проблема стероїдофобії (боязнь тривалого призначення ІІКС) залишається актуальною i серед лікарів. Виникає парадоксальна ситуація. На запитання : Чи вірять лікарі, що ІКС впливають на ріст дитини? 84\% опитаних дають ствердну відповідь. Водночас відповідаючи на запитання : Хто бачив на практиці такий вплив? Отримано відповідь - ніхто не бачив. Що робити в такій ситуації? Багато читати, вчитися, переймати чужий і набувати власний досвід.

На жаль в реальній медичній практиці лікарі нерідко помиляються, і найчастіші помилки, це:

- поліпрагмазія - одночасне призначення багатьох препаратів;

- неоправдано агресивна інфузійна терапія (зачасто i тривало призначають);

- застосування фізіотерапевтичного лікування;

- застосування недозволених засобів для інгаляційного лікування мінеральні води, системні ГКС, антисептики, трав'яні відвари).

Частою помилкою лікарів сьогодні $\epsilon$ заборона фізичних вправ i навантажень для пацієнтів, хворих на бронхіальну астму. Ми забуваємо , що “рух може замінити багато ліків, але ніякі ліки не замінять рух". Треба правильно лікувати бронхіальну астму, а не забороняти фізичні навантаження.

Сьогодні в усьому світі найбільшою проблемою в лікуванні астми $\epsilon$ зниження прихильності пацієнтів до лікування, що призводить до невиконання лікарських призначень. Пацієнти самовільно зменшують дозування базисних препаратів або відставлять їх зовсім, лікуються епізодично (від нападу до нападу), застосовуючи виключно бронхолітичні препарати. Нерідко такі хворі 3 діагностованою бронхіальною астмою безпідставно отримують: антибіотики, відхаркувальні засоби, спазмолітики, імуномодулятори. Саме тому на кожному візиті до лікаря повинна проводитися освітня робота 3 пацієнтом, який має зрозуміти, що не треба шукати добрі антибіотики, не треба шукати противірусні препарати й імуномодулятори, а треба правильно лікувати бронхіальну астму.

На жаль, пацієнти часто не дотримуються лікарських рекомендацій. Проведені протягом останніх років численні дослідження в різних галузях медицини доводять, що 1/3 пацієнтів взагалі не приймає призначені лікарем ліки, 1/3 - самостійно моделює лікарські призначення і лише $1 / 3$ - чемно їх приймає. Нам здається, що ми виписали лік, розказали, як його приймати $\mathrm{i}$ хворий його тільки в такий спосіб і прийматиме, але це не так. Пацієнти нерідко забувають вживати ліки і забувають або не хочуть про це сказати лікарю. Як змінити ситуацію? Нині доведено, що головне завдання - це налагодження співпраці 3 пацієнтом і підвищення його прихильності до лікування, оскільки в таких випадках найчастіше проблема полягає в недотриманні лікарських рекомендацій.

Протягом останніх років майже щороку пропонуються нові узгоджувальні документи, схеми терапії бронхіальної астми, однак досягти контролю хвороби у значної кількості пацієнтів не вдається. Причини такої 
ситуації активно шукають науковці і практики. 3 одного боку, доведено, що практичні лікарі не завжди надають належну увагу освітній роботі 3 пацієнтами. Такі пацієнти самовільно відміняють базисні ліки при покращенні. 3 іншого боку, пацієнти і їх родичі ніби то хочуть щось знати про астму, але не хочуть навчатися. Як змінити ситуацію? Ми мусимо пам'ятати, що хвороба часто змінює психічний стан хворого, який, у свою чергу, впливає на перебіг патологічного процесу й ефективність лікування. Успіх у лікуванні значною мірою визначається налагодженням контакту, взаєморозуміння, співпраці між лікарем, пацієнтом та його родиною. Чи завжди нам це вдається? На жаль, ні. Чому так? Налагодженню доброго контакту з хворим значною мірою «заважає» засилля технології в медицині. Нерідко тривалість різноманітних діагностичних процедур у десятки разів перевищує тривалість спілкування лікаря з пацієнтом i його родиною. Така ситуація часто не дозволяє досягти доброго контакту 3 хворим і породжує конфлікти. У своїй книзі «Утерянное искусство врачевания» Б. Лоун наводить слова, які чітко визначають позицію пацієнта в такій ситуації: «Я не став би просити лікаря приділити мені побільше часу. Я просто хочу, щоб він повністю присвятив мені себе хоча б на п’ять хвилин, став близькою мені людиною, підтримав не лише мою плоть, але й душу, адже люди по-різному переживають хворобу.....». Чи завжди ми маємо для пацієнта цих кілька хвилин? Так, напевне маємо. Але чи завжди ми їх приділяємо хворому? Досвід багатьох поколінь вітчизняних лікарів і наші власні спостереження стали підставою для напрацювання нами своєрідного алгоритму покрокової лікарської тактики.

\section{Перший крок - усміхнутися і привітатися.}

Другий крок - заспокоїти пацієнта і його родину. Не можна залякувати пацієнтів, спокій і психологічний комфорт є надзвичайно важливими. Треба просто переконати пацієнта і його родину, що ми обов'язково досягнемо успіху в лікуванні, якщо вони будуть чітко дотримуватися лікарських рекомендацій.

Третій крок - вияснити ситуацію. Провести детальний збір анамнестичних і об'єктивних даних, оцінити психо-емоційний статус пацієнта. Вияснити яким повітрям він дихає, де живе, чи $\epsilon$ в сім’ї курці. В цьому контексті у медицині існує золоте правило: «Успіх лікаря в його ретельності, якщо хочете навіть у скрупульозності». Дуже часто лікарі не проводять повного огляду пацієнта, звертають увагу лише на бронхіальну астму, пропускаючи алергічний риніт, гастроезофагальний рефлюкс, артеріальну гіпертензію тощо (треба контролювати всі симптоми і одному лікарю).

Четвертий крок - порадити. Лікарські рекомендації повинні бути чіткими, розписаними в письмовій формі. Треба не тільки обрати доброї якості лік i доброї якості інгаляційний пристрій, але навчити пацієнта ним користуватися. І основний момент - треба призначити повторний візит, і під час нього пройтися всіма пунктами своїх письмових рекомендацій i оцінити їх виконання. Хворий повинен піти від нас не зі списком заборонених речей, а 3 чіткими рекомендаціями щодо харчування, способу життя і режиму терапії (о 
котрій годині, в якій послідовності приймати ліки, як вести шоденник самоспостереження, як вести себе під час загострення хвороби тощо).

Здавалося б, прості рекомендації, але чи завжди ми дотримуємося такого алгоритму дій? Напевне, ні.

Як змінити ситуацію? Чи достатньо сьогодні в руках вітчизняних лікарів ефективних засобів для лікування бронхіальної астми? На нашу думку, цілком достатньо. I ми завжди можемо їх застосувати і досягти успіху в лікуванні. Бронхіальна астма сьогодні - хвороба амбулаторна. Кожна госпіталізація поразка в їі лікуванні.

Нині стратегічною метою лікування бронхіальної астми є досягнення повного контролю хвороби, який треба постійно переглядати під час кожного візиту до лікаря. Більше того, треба не просто досягти контролю хвороби, але й враховувати можливі майбутні ризики відсутності контролю (низька прихильність до лікування, помилки в техніці інгалювання, куріння, супутня патологія, зміна екології житла і способу життя тощо). Іншими словами, намагатися вчасно провести редукцію майбутніх ризиків загострення при існуючому доброму контролі симптомів. Коли зберігається загроза відсутності контролю хвороби, необхідно інтенсифікувати лікування.

Відомо, що умови, в яких доводиться працювати лікарям, сьогодні швидко змінюються. Розробляються нові протокольні стандарти діагностики i лікування. Це добре чи погано? Напевне, це правильна дорога, бо нею йде весь світ. Такі стандарти потрібні, одначе їх слід сприймати не як догму, а як рекомендації, які не суперечать одному 3 основних принципів медицини: “лікувати не хворобу, а хворого”. Останні міжнародні узгоджувальні документи стосовно астми відзначають актуальність індивідуалізованого лікування. Варто відзначити, що сучасний менеджмент бронхіальної астми не враховує гетерогенність захворювання i базується на уявленні про еозинофільний характер запалення дихальних шляхів i перебуває у стані пошуку у разі нееозинофільного фенотипу захворювання. Водночас, сьогодні доведено, що хронічне запалення дихальних шляхів, яке $\epsilon$ одним 3 ключових феноменів бронхіальної астми може носити різний характер. Недостатню ефективність контролюючого лікування бронхіальної астми певною мірою пов'язують із гетерогенністю запального процесу в дихальних шляхах, а саме 3 наявністю еозинофільного, нейтрофільного та пауцигранулоцитарного характеру їх запалення, а пошук індивідуалізованого лікування поки що обмежується колом хворих $з$ резистентністю до регламентованої терапії захворювання. Водночас відзначають, що за наявності нейтрофільного характеру запального процесу в бронхах, знижується контроль над бронхіальною астмою 3 розвитком ознак терапевтичної резистентності. Це вимагає індивідуалізованого підходу до лікування. Дана вимога $є$ особливо актуальною, оскільки за останні роки відмічається чітка тенденція до підвищення рівня захворюваності на неалергічну бронхіальну астму, в основі якої, зазвичай, лежить нееозинофільний характер запалення бронхів. Складність проблеми полягає в тому, що діагностика різних запальних фенотипів бронхіальної астми на 
сьогодні залишається недосконалою. Після короткочасного оптимізму прийшло усвідомлення того факту, що варіант запалення бронхів, який визначається за цитологічним складом мокротиння, нерідко непостійний і не може відповісти на всі виклики практичної медицини. Треба враховувати комплекс особливостей бронхіальної астми, а також ії генетичну складову. На сучасному етапі бронхіальну астму розглядають як мультифакторне захворювання, при якому реалізація патологічного процесу визначається взаємодією генетичних факторів і чинників середовища. Не має сумніву в тому, що виділення конкретних фенотипів і ендотипів астми $є$ дуже важливим в контексті вибору терапії і відповіді на лікування, однак на разі зарано впроваджувати такий розподіл у вітчизняну практичну медицину.

Впродовж останніх років ми все більше прагнемо зробити медицину точною наукою. Цьому сприяє широке введення доказової медицини, яка передбачає застосування на практиці лише тих методів лікування і діагностики, ефективність яких доведена на підставі строгих наукових принципів у результаті грамотно організованих клінічних досліджень. Однак, якби ми не намагалися змінити ситуацію, медицина - не математика, медицина - це скоріше мистецтво. I кожний з нас повинен володіти цим мистецтвом, пізнати його правила і водночас кожен з нас має право на свій почерк, який опирається на базові знання i власний досвід. Саме тому у практичній медицині застосовуються різні алгоритми діагностики та лікування і допускаються тактичні помилки. Не помиляється тільки той, хто нічого не робить. У такій ситуації надзвичайно важливою є спроможність лікаря визнати свою помилку і прагнення 


\section{дОДАТКИ}

Додаток 1

\section{Ступені важкості перебігу бронхіальної астми}

\begin{tabular}{|c|c|c|c|c|}
\hline \multirow{3}{*}{ Характеристика } & \multicolumn{4}{|c|}{ Ступінь важкості перебігу захворювання } \\
\hline & \multirow{2}{*}{$\begin{array}{c}\text { інтермітуюча } \\
\text { (епізодична) }\end{array}$} & \multicolumn{3}{|c|}{ Персистуюча } \\
\hline & & легка & середньоважка & важка \\
\hline $\begin{array}{l}\text { Денні } \\
\text { симптоми }\end{array}$ & $\begin{array}{c}\text { < } 1 \text { разу на } \\
\text { тиждень }\end{array}$ & $\begin{array}{c}>1 \text { разу на } \\
\text { тиждень, } \\
\text { але рідше } 1 \\
\text { разу на добу }\end{array}$ & щоденно & щоденно \\
\hline Нічні симптоми & $\begin{array}{l}<2 \text { разів на } \\
\text { місяць }\end{array}$ & $\begin{array}{l}>2 \text { разів на } \\
\text { місяць }\end{array}$ & $\begin{array}{c}\text { > } 1 \text { разу на } \\
\text { тиждень }\end{array}$ & $\begin{array}{c}\text { часті } \\
\text { симптоми }\end{array}$ \\
\hline Загострення & $\begin{array}{c}\text { короткотривалі } \\
\text { (від кількох } \\
\text { годин до } \\
\text { кількох днів) }\end{array}$ & $\begin{array}{c}\text { порушують } \\
\text { активність і } \\
\text { сон }\end{array}$ & $\begin{array}{c}\text { порушують } \\
\text { активність і } \\
\text { сон }\end{array}$ & $\begin{array}{c}\text { часті } \\
\text { загострення }\end{array}$ \\
\hline $\begin{array}{ll}\mathrm{OФФ}_{1} & \text { або } \\
\text { ПОШ }_{\text {вид }} & \text { (від } \\
\text { належного) } & \end{array}$ & $\geq 80 \%$ & $\geq 80 \%$ & $60-80 \%$ & $\leq 60 \%$ \\
\hline $\begin{array}{ll}\text { Добові } & \\
\text { коливання } \\
\text { ПОШ }_{\text {вид }} \text { або } \\
\text { ОФВ }_{1}\end{array}$ & $<20 \%$ & $20-30 \%$ & $>30 \%$ & $>30 \%$ \\
\hline
\end{tabular}

Примітка:

- Наявність однієї з ознак, що відповідає важчому перебігу БА слід віднести до більш важкої категорії.

- Необхідно переглянути ступінь важчості перебігу БА з урахуванням рівню контролю через рік. 


\section{Додаток 2}

Класифікація БА за ступенем контролю

\begin{tabular}{|c|c|c|c|}
\hline Характеристика & $\begin{array}{c}\text { Контрольована } \\
\text { БА } \\
\text { (все } \\
\text { перераховане) }\end{array}$ & $\begin{array}{l}\text { Частково } \\
\text { контрольована } \\
\text { (наявність будь- } \\
\text { якого прояву } \\
\text { протягом тижня) }\end{array}$ & $\begin{array}{c}\text { Неконтрольована } \\
\text { БА }\end{array}$ \\
\hline Денні симптоми & $\begin{array}{l}\text { немає }(\leq 2 \\
\text { епізодів в } \\
\text { тиждень })\end{array}$ & > 2 на тиждень & $\begin{array}{c}\text { наявність } 3 \text { та } \\
\text { більше ознак } \\
\text { частково }\end{array}$ \\
\hline $\begin{array}{l}\text { Обмеження } \\
\text { активності }\end{array}$ & Немає & $\begin{array}{c}\epsilon, \text { будь-якого } \\
\text { прояву }\end{array}$ & $\begin{array}{c}\text { контрольованої } \\
\text { БА протягом }\end{array}$ \\
\hline $\begin{array}{l}\text { Нічні симптоми/ } \\
\text { пробудження }\end{array}$ & Немає & $\begin{array}{c}\epsilon, \text { будь-якого } \\
\text { прояву }\end{array}$ & тижня \\
\hline $\begin{array}{l}\text { Потреба в } \\
\text { препаратах } \\
\text { невідкладної } \\
\text { допомоги }\end{array}$ & $\begin{array}{l}\text { немає ( } \leq 2 \\
\text { епізодів в } \\
\text { тиждень) }\end{array}$ & $>2$ на тиждень & \\
\hline $\begin{array}{lr}\text { Показники } & \\
\text { функції } & \text { легень } \\
\text { (ПОШ }_{\text {вид }} & \text { або } \\
\text { ОФВ1)** } & \end{array}$ & Норма & $\begin{array}{c}<80 \% \text { від належної } \\
\text { величини (або } \\
\text { найкращого } \\
\text { показника для } \\
\text { даного пацієнта) }\end{array}$ & \\
\hline Загострення & Немає & 1 або > на рік* & $\begin{array}{c}\text { Будь-який } \\
\text { тиждень i3 } \\
\text { загостренням * }\end{array}$ \\
\hline \multicolumn{4}{|c|}{$\begin{array}{l}\text { Примітка: } \\
\text { * - кожне загострення потребує негайного перегляду базисної терапії та } \\
\text { оцінки їі адекватності; за визначенням, розвиток загострення свідчить про те, } \\
\text { що БА не контрольована; } \\
\text { ** - спірометрія не є надійним методом дослідження у дітей до } 5 \text { років. }\end{array}$} \\
\hline
\end{tabular}


Додаток 3

Критерії важкості загострень бронхіальної астми у дітей

\begin{tabular}{|c|c|c|c|c|}
\hline Показник & $\begin{array}{c}\text { Легке } \\
\text { загострення }\end{array}$ & $\begin{array}{c}\text { Середньоважке } \\
\text { загострення }\end{array}$ & $\begin{array}{c}\text { Важке } \\
\text { загострення }\end{array}$ & $\begin{array}{c}\text { Загроза } \\
\text { асфіксії } \\
\text { (астматичний } \\
\text { стан) }\end{array}$ \\
\hline Задишка & $\begin{array}{c}\text { під час } \\
\text { ходи }\end{array}$ & $\begin{array}{c}\text { Під час } \\
\text { розмови, } \\
\text { труднощі під } \\
\text { час годування, } \\
\text { сидить }\end{array}$ & $\begin{array}{c}\text { є у спокої, } \\
\text { відмовляється } \\
\text { їсти, сидить } \\
\text { нахилившись } \\
\text { уперед }\end{array}$ & $\begin{array}{c}\text { ризик } \\
\text { припинення } \\
\text { дихання }\end{array}$ \\
\hline Мова & речення & окремі фрази & окремі слова & не розмовляє \\
\hline Поведінка дитини & $\begin{array}{l}\text { може бути } \\
\text { збудженим }\end{array}$ & $\begin{array}{c}\text { частіше } \\
\text { збуджений }\end{array}$ & збуджений & $\begin{array}{c}\text { загальмований } \\
\text { або в стані } \\
\text { сплутаної } \\
\text { свідомості }\end{array}$ \\
\hline Частота дихання* & $\begin{array}{c}\text { збільшена } \\
\text { до } 30 \text { \% від } \\
\text { вікових } \\
\text { величин }\end{array}$ & $\begin{array}{c}\text { збільшена до } \\
30 \text { \% від } \\
\text { вікових } \\
\text { величин }\end{array}$ & $\begin{array}{c}\text { збільшена } \\
\text { більше ніж } 30 \\
\% \text { від вікових } \\
\text { величин }\end{array}$ & $\begin{array}{c}\text { парадоксальне } \\
\text { дихання }\end{array}$ \\
\hline $\begin{array}{l}\text { Участь в акті } \\
\text { дихання } \\
\text { допоміжної } \\
\text { мускулатури }\end{array}$ & Немає & $\epsilon$ & $\begin{array}{c}\text { значно } \\
\text { виражене }\end{array}$ & $\begin{array}{c}\text { парадоксальні } \\
\text { рухи грудної } \\
\text { клітки та } \\
\text { черевної } \\
\text { стінки }\end{array}$ \\
\hline $\begin{array}{l}\text { Свистячі } \\
\text { дистанційні } \\
\text { хрипи }\end{array}$ & Немає & помірні & гучні & $\begin{array}{l}\text { відсутні («німі } \\
\text { легені») }\end{array}$ \\
\hline $\begin{array}{l}\text { Частота серцевих } \\
\text { скорочень** }\end{array}$ & нормальна & $\begin{array}{c}\text { збільшена на } \\
20 \text { - } 30 \text { \% від } \\
\text { належних } \\
\text { вікових } \\
\text { величин }\end{array}$ & $\begin{array}{c}\text { збільшена } \\
\text { більш ніж на } \\
30 \text { \% від } \\
\text { належних } \\
\text { вікових } \\
\text { величин }\end{array}$ & брадикардія \\
\hline $\begin{array}{l}\text { ПОШВ після } \\
\text { застосування } \\
\text { бронходилятатору }\end{array}$ & $>80 \%$ & $60-80 \%$ & $<60 \%$ & $\begin{array}{c}\text { труднощі } \\
\text { вимірювання }\end{array}$ \\
\hline $\begin{array}{l}\mathrm{Pa} \mathrm{O}_{2} \text { (при } \\
\text { диханні повітрям) }\end{array}$ & $\begin{array}{c}\text { норма, } \\
\text { немає } \\
\text { потреби }\end{array}$ & $>60$ мм рт. ст. & $\begin{array}{c}<60 \text { мм рт. } \\
\text { ст. } \\
\text { можливий }\end{array}$ & $<60$ мм рт. ст. \\
\hline
\end{tabular}




\begin{tabular}{|c|c|c|c|c|}
\hline & вимірювати & & ціаноз & \\
\hline $\begin{array}{l}\mathrm{Pa} \mathrm{CO}_{2} \text { (при } \\
\text { диханні повітрям) }\end{array}$ & $\begin{array}{c}<45 \text { мм рт. } \\
\text { ст. }\end{array}$ & $<45$ мм рт. ст. & $\begin{array}{c}>45 \text { мм рт. } \\
\text { ст. }\end{array}$ & $>45$ мм рт. ст. \\
\hline $\begin{array}{l}\text { Sat } \mathrm{O}_{2} \text { (при } \\
\text { диханні повітрям) }\end{array}$ & $95 \%$ & $91-95 \%$ & $<90 \%$ & $<90 \%$ \\
\hline $\begin{array}{l}\text { Парадоксальний } \\
\text { пульс*** }\end{array}$ & $\begin{array}{c}\text { Немає } \\
<10 \text { мм рт. } \\
\text { ст. }\end{array}$ & $\begin{array}{c}\text { може бути } \\
\text { 10-25 мм рт. } \\
\text { ст. }\end{array}$ & $\begin{array}{c}\text { часто } \\
\text { присутній } \\
25 \text { мм рт. ст. - } \\
\text { діти старшого } \\
\text { віку; 20-40 } \\
\text { мм рт. ст. - } \\
\text { діти раннього } \\
\text { віку }\end{array}$ & $\begin{array}{c}\text { відсутність } \\
\text { свідчить про } \\
\text { втому } \\
\text { дихальних } \\
\text { м’язів }\end{array}$ \\
\hline
\end{tabular}

Примітка: Важкість загострень характеризується наявністю декількох ознак, але не обов'язково усіх.

* Нормальна частота дихання у дітей після просинання:

Вік

Частота дихання

Менше 2 місяців

менше 60 за хвилину

2-12 місяців

менше 50 за хвилину

$1-5$ років

менше 40 за хвилину

6-8 років

менше 30 за хвилину

** Нормальна частота серцевих скорочень у дітей:

2-12 місяців

менше 160 за хвилину

1-2 років

менше 120 за хвилину

2-8 років

менше 110 за хвилину

*** Парадоксальний пульс - зниження систолічного артеріального тиску (АТ) під час нормального вдиху більше, ніж 10 мм рт. ст. порівняно із здоровими однолітками. Цей феномен типовий для обструктивних захворювань дихальних шляхів і тампонади серця. У здорових людей систолічний АТ під час нормального вдиху може знижуватися на величину до 10 мм рт. ст. Sat $\mathrm{O}_{2}$ (Сатурація $\mathrm{O}_{2}$ ) - насичення крові киснем. 


\section{Додаток 4}

\section{ПІКФЛОУМЕТРІЯ}

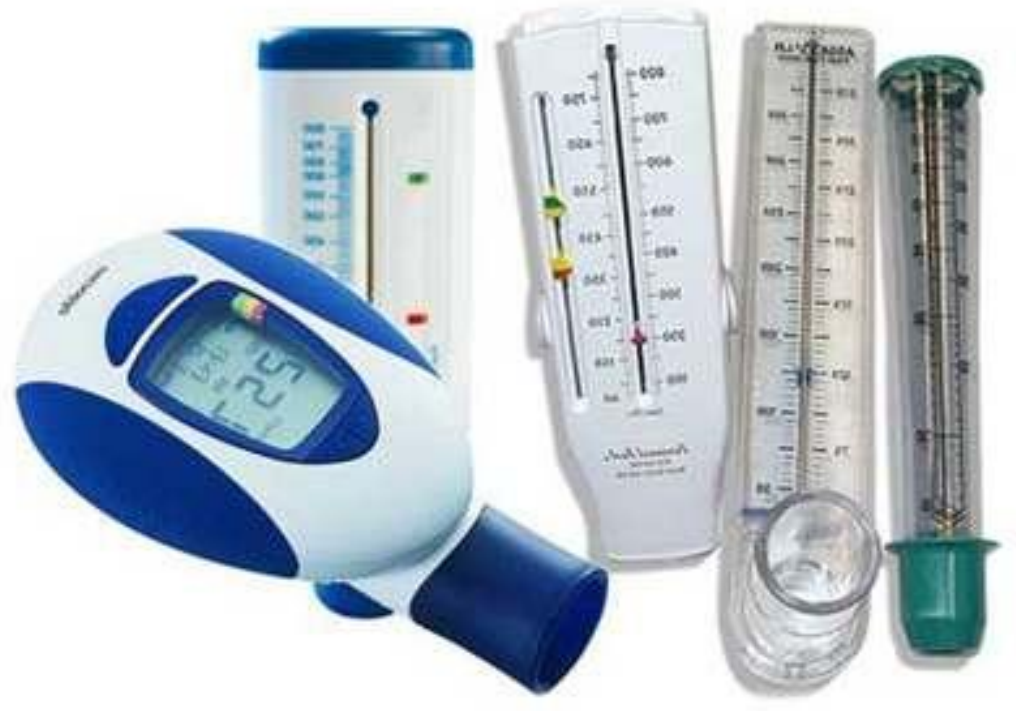

Пікфлоуметри

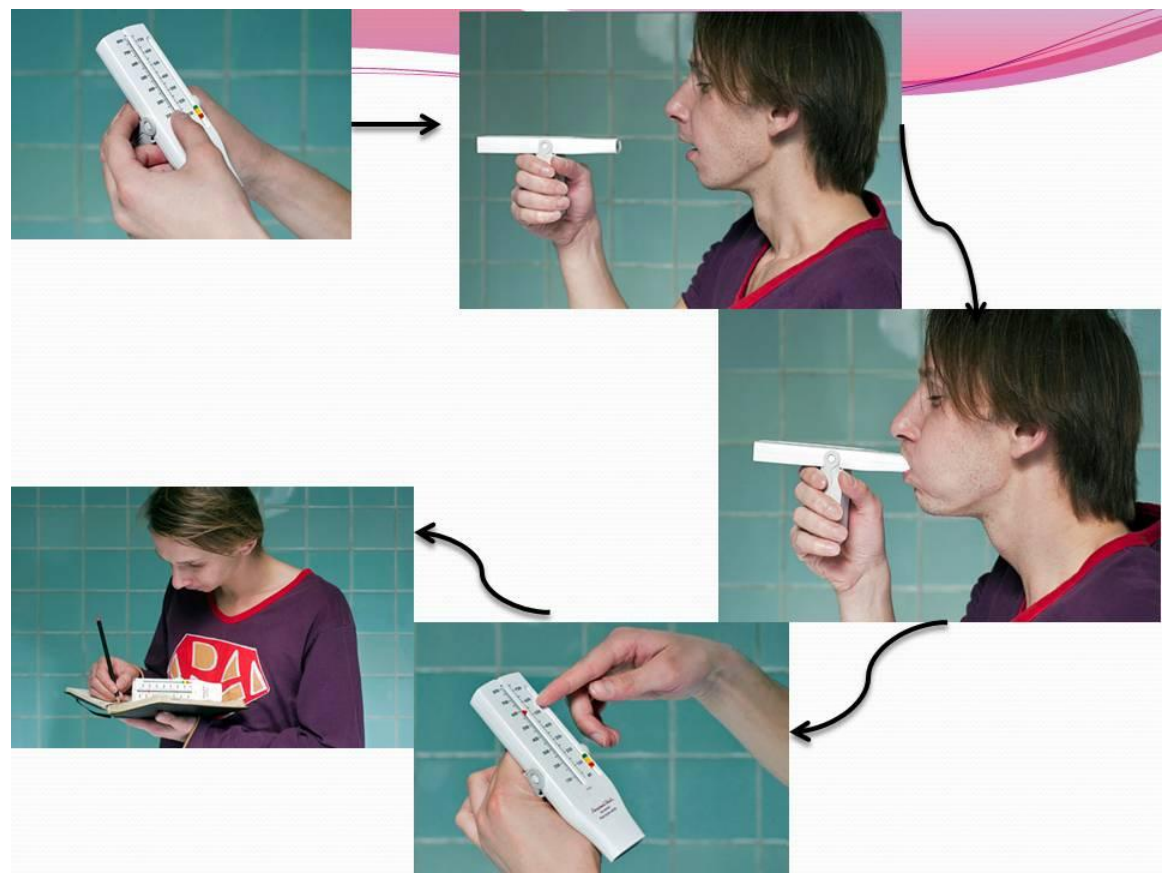

\section{Правила користування пікфлуометром}

Існують різні види пікфлоуметрів, однак правила їх використання однакові. Вимірювання слід проводити стоячи або, в крайньому разі, сидячи. Перед проведенням дослідження необхідно швидко і глибоко вдихнути, після чого різко видихнути повітря у прилад - здійснити максимально швидкий видих. Дітям треба пояснити, що видих повинен бути якнайшвидший i 
якнайпотужніший. Вони повинні дмухнути так само, як тоді, коли намагаються одномоментно задмухнути всі свічки на іменинному торті.

Під час видиху стрілка (бігунець) пікфлоуметра відхиляється і вказує на показник пікової швидкості видиху, який вимірюється у л/хв. Необхідно зробити підряд 3 спроби і вибрати з них найкращий показник, який заноситься у спеціальний щоденник. Нормальні показники пікфлоуметрії визначаються лікарем індивідуально для кожної дитини і залежать від статі, віку та зросту. ПОШ величин. 



\section{Додаток 5}

\section{Препарати для лікування бронхообструктивного синдрому з урахуванням впливу на серцево-судинну систему}

\begin{tabular}{|c|c|}
\hline Препарат & Можливі побічні дії \\
\hline Атропін & $\begin{array}{l}\text { Вплив майже на всі органи та системи : зорові розлади, сухість слизових оболонок, } \\
\text { атонія сечового міхура та кишківника, тахікардія, неспецифічні ефекти центральної } \\
\text { нервової системи та психоміметична активність. }\end{array}$ \\
\hline Іпратропіуму бромід (атровент) & $\begin{array}{l}\text { Може застосовуватись у пацієнтів з серцевими і иркуляторними порушеннями. } \\
\text { Обережно слід застосовувати у пацієнтів з глаукомою, гіпертрофією простати, хоча } \\
\text { ризик розвитку ускладнень від терапевтичної дози мінімальний. } \\
\text { Абсолютним протипоказанням є гіперчутливість до атропіноподібних речовин. }\end{array}$ \\
\hline Тіотропію бромід (спірива) & $\begin{array}{l}\text { Тривале застосування тіотропію проявляється у достовірному зменшенні ризику } \\
\text { розвитку побічних явищ з боку серцево-судинної та дихальної системи за рахунок } \\
\text { кардіопротекторного впливу. }\end{array}$ \\
\hline сальбутамол(вентолін),фенотерол(беротек) & 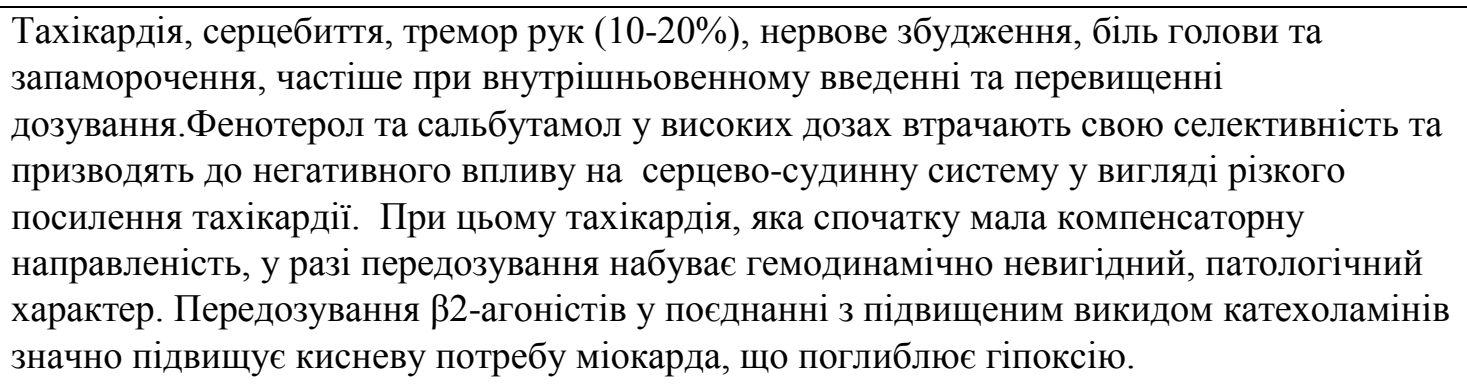 \\
\hline Сальметерол (серевент) - & $\begin{array}{l}\text { Побічні ефекти серевенту практично відсутні. } \\
\text { Призначення з кетоконазолом для системного застосування може призвести до } \\
\text { посиленого серцебиття та подовження інтервалу } Q-T \text {. Слід уникати одночасного } \\
\text { призначення з кетоконазолом та іншими інгібіторами СРР ЗА, за винятком } \\
\text { ключенням випадків, коли користь перевищує потенціальний ризик. У пацієнтів з } \\
\text { високою чутливістю реєструються аритмії (фібріляція передсердь, надшлуночкова } \\
\text { тахікардія та екстрасистолія). Окремі повідомлення про розвиток гіперглікемії. }\end{array}$ \\
\hline Формотерол & Побічні дії подібні до салметеролу. \\
\hline
\end{tabular}




\begin{tabular}{|c|c|}
\hline $\begin{array}{l}\text { Фенотерол + іпратропіума бромід } \\
\text { (беродуал, дуовент) }\end{array}$ & $\begin{array}{l}\text { Побічні дії беродуалу значно менші, що дозволяє його застосовувати при плановій } \\
\text { терапії, коли добовий ліміт фенотеролу повністю вичерпано. }\end{array}$ \\
\hline Теофілін (еуфілін) & $\begin{array}{l}\text { Токсичний ефект теофілліну проявляється у вигляді швидкого падіння } \\
\text { артеріального тиску, підвищення загального збудження, безсоння, тахікардії, } \\
\text { подразнення ЖКТ, шкірного висипу. } 3 \text { урахуванням малої різниці між } \\
\text { оптимальною терапевтичною та мінімальною токсичною дозами слід проводити } \\
\text { моніторинг концентрації теофіліну в крові при внутрішньовенному введенні. } \\
\text { Важливі ефекти: } \\
\text { - } \quad \text { При хронічній та гострій серцевій недостатності, набряку легень відбувається зниження } \\
\text { кліренса в } 2 \text { і більше разів. } \\
\text { - } \quad \text { При гепатитах та цирозах печінки, асциті відбувається збільшення періоду } \\
\quad \text { напіввиведення до } 6 \text { разів. } \\
\text { - } \quad \text { При гіпопротеінемії збільшення концентрації та прояви інтоксикації при С >30 мкг/мл } \\
\text { - } \quad \text { При гіпертіреозі збільшення швидкості елімінації в } 4 \text { рази } \\
\text { - } \quad \text { При гіпотіреозі зменшення швидкості елімінації в 1,5 рази. }\end{array}$ \\
\hline Пролонговані форми теофіліна(теопек) & В більшості випадків пролонговані форми не супроводжуються побічними діями \\
\hline Рофлуміласт & $\begin{array}{l}\text { Під час проведення клінічних досліджень у пацієнтів з ХОЗЛ приблизно у 16\% з них } \\
\text { виникали небажані реакції після прийому рофлуміласта (плацебо-група - у 5\% } \\
\text { пацієнтів). Частіше за все: діарея(5,9\%), зниженнямаси тіла (3,4\%), нудота (2,9\%), біль } \\
\text { в животі (1,9\%), головний біль (1,7\%). Взаємодія з препаратами: Не спостерігається } \\
\text { взаємодії з сальбутамолом, формотеролом, будесонідом, монтелукастом, дігоксином та } \\
\text { варфарином.- Підвищення дії. Клінічні дослідження взаємодії з інгібіторами } \\
\text { цитохрому СҮР3А4 эритроміцином та кетоконазолом показали збільшення загальної } \\
\text { пригнічуючої активності РDE4 на 9\% (загальна експозиція рофлуміласта и N- } \\
\text { оксидарофлуміласта). При взаємодії з пероральними контрацептивами (гестоден та } \\
\text { етинілестрадіол) загальна пригнічуюча активність РDE4 >17\%. Зниження дії - прийом } \\
\text { індуктора Р450 рифампіцину призводить до зниження активностіРDE4 на 60\%. } \\
\text { Одночасне застосування з теофіліном - зниження активностіPDE4 на } 8 \% \text {. }\end{array}$ \\
\hline
\end{tabular}




\begin{tabular}{|l|l|}
\hline Преднізолон, дексазон & $\begin{array}{l}\text { Тривала терапія кортикостероїдами у пацієнтів з ХОЗЛ призводить до розвитку } \\
\text { гіпокаліємії та пресорного впливу на судини, тому при лікуванні артеріальної } \\
\text { гіпертензії варто обмежити застосування препаратів, що виводять калій (сечогіні } \\
\text { засоби). }\end{array}$ \\
\hline Флутиказонупропіонат(фліксотид) & $\begin{array}{l}\text { Завдяки дуже низькому рівню системної дії побічні ефекти фліксотиду практично } \\
\text { відсутні. }\end{array}$ \\
\hline Будесонід & $\begin{array}{l}\text { Метаболізм будесоніду головним чином, опосередкований СҮР3А4,під сімейством } \\
\text { цитохрому Р } \text { 450. Інгібітори цього ферменту, наприклад, кетоконазол, можуть } \\
\text { підвищувати системний вплив будесоніду. Для короткотривалого (1-2тижні) лікування } \\
\text { клінічна значимість обмежена, але слід враховувати під час довготривалого лікування } \\
\text { кетоконазолом. Підтримувальна терапія не рекомендована паціентам, що застосовують } \\
\text { потенційні інгібітори СҮРзА4 }\end{array}$ \\
\hline Серетид & $\begin{array}{l}\text { Поодинокі реакції, пов'язані з механімами дії серевенту та фліксотиду. } \\
\text { Додаткові побічні ефекти при одночасному застосуванні 2 компонентів } \\
\text { препарату не зареєстровані.Слід з обережністю застосовувати у пацієнтів, які } \\
\text { страждають на тяжкі серцево-судинні порушення (включаючи порушення } \\
\text { серцевого ритму), цукровий діабет, не ліковану гіпокаліємію або тиреотоксикоз. }\end{array}$ \\
\hline Симбікорт & $\begin{array}{l}\text { Поодинокі реакції, пов’язані з механімами дії формотеролу та будесоніду. Додаткові } \\
\text { побічні ефекти при одночасному застосуванні 2 компонентівпрепарата не } \\
\text { зареєстровані. }\end{array}$ \\
\hline
\end{tabular}





\section{Додаток 6}

Схема базисної покрокової терапії бронхіальної астми у дорослих

\begin{tabular}{|c|c|c|c|c|}
\hline Крок 1 & Крок 2 & Крок 3 & Крок 4 & Крок 5 \\
\hline \multicolumn{5}{|c|}{$\begin{array}{c}\text { Астма-навчання } \\
\text { Контроль оточуючого середовища }\end{array}$} \\
\hline \multicolumn{5}{|c|}{ Бета 2-агоністи швидкої дії “за потребою” } \\
\hline \multirow[t]{4}{*}{$\begin{array}{c}\text { Контролююча } \\
\text { терапія }\end{array}$} & Виберіть одне & Виберіть одне & $\begin{array}{l}\text { Додати одне або } \\
\text { більше }\end{array}$ & $\begin{array}{l}\text { Додати одне } \\
\text { або обидва }\end{array}$ \\
\hline & $\begin{array}{c}\text { Низькі дози } \\
\text { ІКС }\end{array}$ & $\begin{array}{c}\text { Низькі дози ІКС+ } \\
\text { бета 2-агоніст } \\
\text { пролонгованої дії }\end{array}$ & $\begin{array}{c}\text { ІКС у середній або } \\
\text { високій дозі + } \\
\text { бета 2-агоніст } \\
\text { пролонгованої дії }\end{array}$ & $\begin{array}{c}\text { Перорально } \\
\text { КС } \\
\text { (мінімально } \\
\text { ефективні } \\
\text { дози) }\end{array}$ \\
\hline & $\begin{array}{l}\text { Модифікатори } \\
\text { лейкотриєнів }\end{array}$ & $\begin{array}{c}\text { ІКС у середніх } \\
\text { або високих дозах } \\
\text { Низькі дози ІКС+ } \\
\text { модифікатори } \\
\text { лейкотрієнів }\end{array}$ & $\begin{array}{c}\text { Модифікатори } \\
\text { лейкотрієнів } \\
\text { Теофіліни } \\
\text { сповільненого } \\
\text { вивільнення }\end{array}$ & Анти IgE \\
\hline & & $\begin{array}{c}\text { Низькі дози ІКС+ } \\
\text { теофіліни } \\
\text { сповільненого } \\
\text { вивільнення }\end{array}$ & & \\
\hline
\end{tabular}





\section{Додаток 7}

\section{Астма контроль тест}

\begin{tabular}{|c|c|}
\hline Запитання & Варіанти відповіді \\
\hline $\begin{array}{l}\text { 1. Як часто протягом останніх } 4 \\
\text { тиж астма заважала Вам } \\
\text { виконувати звичайний обсяг } \\
\text { завдань (на роботі, на навчанні чи } \\
\text { вдома)? }\end{array}$ & $\begin{array}{l}1 \text { - постійно } \\
2 \text { - дуже часто } \\
3 \text { - іноді } \\
4 \text { - зрідка } \\
5 \text { - ніколи }\end{array}$ \\
\hline $\begin{array}{l}\text { 2. Як часто протягом останніх } 4 \\
\text { тиж Ви відзначали у себе } \\
\text { утруднене дихання? }\end{array}$ & $\begin{array}{l}1 \text { - частіше ніж } 1 \text { раз на день } \\
2 \text { - } 1 \text { раз на день } \\
3 \text { - від } 3 \text { до } 6 \text { разів на тиждень } \\
4-1-2 \text { рази на тиждень } \\
5 \text { - жодного разу }\end{array}$ \\
\hline $\begin{array}{l}\text { 3. Як часто протягом останніх } 4 \\
\text { тиж Ви прокидалися вночі або } \\
\text { раніше, ніж звичайно, через } \\
\text { симптоми астми (свистячого } \\
\text { дихання, кашлю, утрудненого } \\
\text { дихання, відчуття стиснення } \\
\text { у грудях або болю у грудях)? }\end{array}$ & $\begin{array}{l}1->4 \text { ночей на тиждень } \\
2-2-3 \text { ночі на тиждень } \\
3-1 \text { раз на тиждень } \\
4-1-2 \text { рази } \\
5 \text { - жодного разу }\end{array}$ \\
\hline $\begin{array}{l}\text { 4. Як часто протягом останніх } \\
4 \text { тиж Ви використовували } \\
\text { інгалятор «швидкої допомоги» або } \\
\text { небулайзер (такі як сальбутамол)? }\end{array}$ & $\begin{array}{l}1->3 \text { рази на день } \\
2-1-2 \text { рази на день } \\
3-2-3 \text { рази на день } \\
4-<1 \text { рази на тиждень } \\
5 \text { - жодного разу }\end{array}$ \\
\hline $\begin{array}{l}\text { 5. Як би Ви оцінили, наскільки Вам } \\
\text { вдавалося контролювати астму } \\
\text { протягом останніх } 4 \text { тиж? }\end{array}$ & $\begin{array}{l}1 \text { - зовсім не вдавалося } \\
2 \text { - погано } \\
3 \text { - деякою мірою } \\
4 \text { - добре } \\
5 \text { - повністю вдавалось } \\
\text { контролювати }\end{array}$ \\
\hline Загальна оцінка (сума балів ) & \\
\hline
\end{tabular}

Сума в 25 балів означає повний контроль бронхіальної астми.

Сума 20-24 бали означає, що бронхіальна астма контролюється добре.

Сума $\leq 19$ балів свідчить про неконтрольовану бронхіальну астму. 

Pис. 1

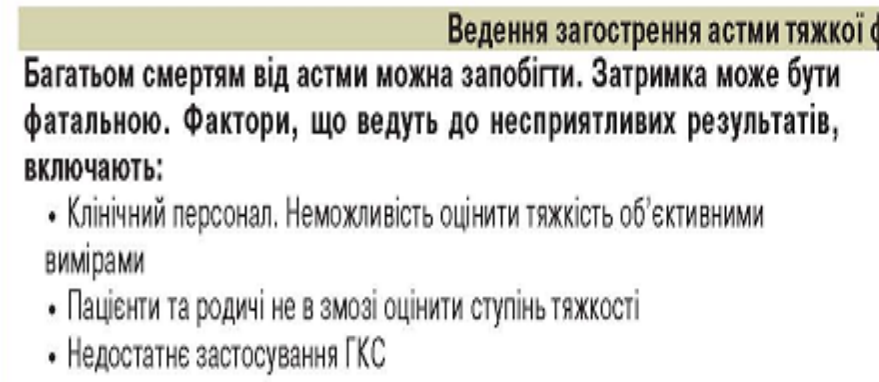

Розглядайте кожну надзвичайну ситуацію при БА як загострення астми тяжкої форми, поки не буде виявлено щось інше.

Помірне загострення астми
ПОШ $>$ вна.
$>50-75 \%$ чи кращий від належного
- $\mathrm{SaO}_{2} \geqslant 92 \%$
- Мова нормальна
- Дихання <25 вдихів/хв
- Пульс <110 уд,/хв
v

Загострення астми тяжкої форми
Початкова оцінка
ПОШ $33-50 \%$ чи кращий від налехного
Загрозлива для життя астма

• ПОШ

- симттоми і відповідь на саме лікування;

- ЧСС і частоту дихання;

- насичення киснем (за пульсоксиметрією).

Увага! Пацівнти з тяжким чи небезпечним для хиття нападом мохуть мати всі нижченаведені порушення, але не повинні засмучуватися. Наявність будь-яких порушень має насторохити лікаря.
ПОШ $33-50 \%$ 4и кращий від належного

Подальша оцінка

- $\mathrm{SaO}_{2} \geqslant 92 \%$

- Не мохе закінчити речення на одному диханні

- Дихання $\geqslant 25$ вдихів/хв

- Пульс $\geqslant 110$ ув. $/$ хв $_{1}$

- $\mathrm{SaO}_{2} \geqslant 92 \%$ зусилля

- Аритмія або гіпотензія
- нHiмах легеня, ціаноз або недостатні дихальні

- Виснаження, зміна свідомості

V

Ведення

Розгляньте госпіталізацію

Організуйте термінову госпіталізацію
Лікуйте вдома або в стаціонарі й ОЦІНЮЙТЕ ВІДПОВІДЬ НА ЛІКУВАННЯ

$\nabla$

\section{V}

V

\section{Лікування}

Бета, -бронходилататори: через спейсер (4 вприскування спочатку і ще 2 вприскування кохні 2 хв залежно від відловіді- максимум до 10 вприскувань) Якщо ПОШ $>$ ви. $50-75 \%$ належного/найкращого:

- дайте преднізолон 40-50 мг;

- продовжуйте підвищувати сходинку лікування.

Якщо хороша відповідь на початкове лікування (симптоми зменшилися, дихання і пульс врегульовані і ПОШ $>50 \%$ ), продовхуйте, як і раніше, або підвищуйте сходинку лікування і продовхуйте прийом преднізолону

Госпіталізуйте, якщо є:

- небезпечні для Хиття ознаки;

- ознаки тяххого загострення астми зберігаються після первинного лікування;

- в анамнезі попередне вахке загострення астми.

Знизити поріг для госпіталізації, якщо напади вдень або вночі, останні нічні симптоми або госпіталізація, попередні тяжкінапади, паціент не в змозі оцінити власний стан або важливість соціальних обставин.

Алгоритм лікування загострення БА
- Кисень для підтримки $\mathrm{SaO}_{2}$ 94-98\% - у разі доступності

- Бета, -бронходилататор: через спейсер

4 вприскування спочатку, в подальшому -

2 вприскування кохні 2 хв залехно від відповіді не більше 10

- Преднізолон 40-50 мг або внутрішньовенно

гідрокортизон $100 \mathrm{mr}$

- У разі відсутності відповіді при тяжкому

загостренні астми - госпіталізація

\section{V}

\section{За необхідності госпіталізації:}

- залишайтеся з пацівнтом до прибуття швидкоі

допомоги;

- передайте писымову оцінку та деталі направлення

до лікарні;;

- небулізація бета -бронходилататорами із засто.

суванням небулайзера з керованим киснемв маши-

ні швидкоі допомоги.
- Кисень для підтримки $\mathrm{SaO}_{2} 94-98 \%$

- Бета -бронходилататор та іпратропію бромід: - через спейсер (4 вприскування спочатку і даліпо 2 вприскування кохні 2 хв залехно від відловіді - не більше 10

- преднізолон 40-50 мг або внутрішньовенно або гідрокортизон 100 мг негайно

\section{$\nabla$}

Спостерігайте за пацієнтом після лікування або виписування з пікарні:

- огляд лікарем загальної практики впродовж 48 год;

- моніторуйте симптоми іПОШ

- перевірте техніку інгаляції;

- письмовий план дій при астмі;

- розгляньте фактори, які потенційно мохна попередити, щоб уникнути госпіталізації. 
Додаток 9

Стандартна схема АCIT неінфекційними аллергенами

\begin{tabular}{|l|l|l|l|l|l|l|l|l|l|l|}
\hline $\begin{array}{l}\text { Розведе- } \\
\text { ння } \\
\text { алергену }\end{array}$ & \multicolumn{9}{|c|}{} & \multicolumn{9}{|c|}{ Доза, мл } \\
\hline $10^{-8}$ & 0.1 & 0.2 & 0.3 & 0.4 & 0.5 & 0.6 & 0.7 & 0.8 & 0.9 & Щодня \\
\hline $10^{-7}$ & 0.1 & 0.2 & 0.3 & 0.4 & 0.5 & 0.6 & 0.7 & 0.8 & 0.9 & Щодня \\
\hline $10^{-6}$ & 0.1 & 0.2 & 0.3 & 0.4 & 0.5 & 0.6 & 0.7 & 0.8 & 0.9 & Щодня \\
\hline $10^{-5}$ & 0.1 & 0.2 & 0.3 & 0.4 & 0.5 & 0.6 & 0.7 & 0.8 & 0.9 & Щодня \\
\hline $10^{-4}$ & 0.1 & 0.2 & 0.3 & 0.4 & 0.5 & 0.6 & 0.7 & 0.8 & 0.9 & Щодня \\
\hline $10^{-3}$ & 0.1 & 0.2 & 0.3 & 0.4 & 0.5 & 0.6 & 0.7 & 0.8 & 0.9 & Через 1-2 дні \\
\hline $10^{-2}$ & 0.1 & 0.2 & 0.3 & 0.4 & 0.5 & 0.6 & 0.7 & 0.8 & 0.9 & Через 2-3 дні \\
\hline $10^{-1}$ & 0.1 & 0.2 & 0.3 & 0.4 & 0.5 & & & & & $\begin{array}{l}\text { Ч-2 рази на } \\
\text { тиждень }\end{array}$ \\
\hline & & & & & & & & & & \\
\hline
\end{tabular}




\section{1. ЛІТЕРАТУРА}

2. Безруков Л.О. Фенотипи бронхіальної астми : міф чи реальність? / Л.О. Безруков, О.К.Колоскова, Л.А. Іванова. - Чернівці : Місто. - 2015. $162 \mathrm{c}$.

3. Беш Л.В. Бронхіальна астма у дітей.-Львів «Каменяр».- 2010.- 85с.

4. Колоскова О.К. Особливості запальної відповіді у дітей шкільного віку, хворих на бронхіальну астму / О.К. Колоскова, С.І. Тарнавська, Т.О. Лобанова // Астма і алергія. - 2017. - № 1. - С. 17-22.

5. Костроміна В. П. Фактори ризику виникнення бронхіальної астми у дітей / В. П. Костроміна, О. О. Речкіна, К. О. Мельник, А. С. Дорошенкова, В. О. Стриж, Л. Б. Ярощук // Астма та алергія. - 2013. - № 2. - С. 21-24.

6. Ксенофонтова В.А. Аллергенспецифическая иммунотерапия аллергенами клещей домашней пыли / В.А. Ксенофонтова, В.М. Бержец, Т.Г. Федоскова // Иммунопатология, аллергология, инфектология. 2013. - №3. - C. 47-53.

7. Курбачева О.М. Высокодозная сублингвальная иммунотерапия: целесообразность и безопасность / О.М. Курбачева, К.С. Павлова // Рос. аллергологический журн. - 2014. - № 3. - С. 63-67.

8. Ласица О.И., Ласица Т.С. Бронхиальная астма в практике семейного врача.- Киев: 3АО «Атлант UMS», 2001. - 263с.

9. Мушак, І. 3. „Дитяча” і „доросла” бронхіальна астма: чи існує зв’язок? [Текст] / I. 3. Мушак, Л. В. Беш // Здобутки клінічної та експериментальної медицини. - 2007. - № 1. - С. 7-14.

10.Недельська С.М. Ефективність алерген-специфічної імунотерапії у дітей 3 бронхіальною астмою / С.М. Недельська, Н.М.Марчук // Здоровье ребенка. - 2013. - №1. - С. 22-26

11.Охотникова Е.Н. Бронхиальная астма и аллергический ринит у детей до 6 лет: особенности терапии коморбидной патологии / Е.Н. Охотникова, Е.В. Шарикадзе // Современная педиатрия. - 2015. - № 8 (72). - С. $110-116$.

12.Перцева Т.О. Труднощі диференційного діагностики при бронхіальній астмі / Т.О. Перцева / Здоров'я України. - 2016. - №3 (34). - с. 24-26.

13.Перцева Т.А. ХОЗЛ и сопутствующие заболевания - сложный пациент в фокусе междисциплинарной проблемы / Т.А. Перцева // Здоровье Украины. - 2010. — № 7 (236). - С. 18-19.

14.Победенная Г. П. К вопросу о коморбидной патологии: бронхиальная астма и ожирение / Г.П. Победенная, С.В. Ярцева // Астма і алергія. 2014. - № 2. - C. 54-61. 
15.Протокол надання медичної допомоги хворим на бронхіальну астму // Рациональная фармакотерапия. - 2007. - №3. - С. 72-75.

16.Радченко О.М. Фенотип бронхіальної астми з ожирінням / О.М. Радченко, О. Р. Слаба // Астма і алергія. - 2014. - № 2. - 19-21.

17.Сучасні підходи до алерген-специфічної імунотерапії при алергічних захворюваннях органів дихання у дітей / Б.М. Пухлик, І.В. Гогунська, І.В. Коряцька [та ін.] // Журнал вушних, носових та горлових хвороб. - 2013. - № 1. - C. 52-58.

18.Уманець Т.Р. Бронхиальная астма и аллергический ринит: пути оптимизации комплайенса и ефективности лечения // Т.Р. Уманець // Астма і алергія. — 2015. - № 1. - С. 61-64.

19.Уманець Т.Р. Місце небулайзерної терапії в лікуванні загострень бронхіальної астми у дітей: ефективність небутамолу / Т.Р. Уманець // Астма і алергія. — 2016. - № 4. - С. 45-51.

20.Уніфікований клінічний протокол первинної, вторинної (спеціалізованої) медичної допомоги “Бронхіальна астма у дітей” (Наказ МО3 України №868 від 08 жовтня 2013 р.). і протокол дорослих

21.Фактори ризику виникнення бронхіальної астми у дітей / В.П. Костроміна, О.О. Речкіна, К.О. Мельник [та ін.] // Астма і алергія. 2013. - № 2. - С. 21-24.

22.Фещенко Ю.І. Відновлення фізичної активності у хворих на бронхіальну астму / Ю.І. Фещенко, Н.А. Примушко, Н.В. Пархоменко та ін..// Астма і алергія. - 2017. - № 1. - С. 17-22.

23.Фещенко Ю.І. Дослідження фунції зовнішнього дихання при комплексному лікування хворих на поєднану патологію бронхіальної астми та хронічного обструктивного захворювання легень / Ю.І. Фещенко, Л.О. Яшина, К.В. Назаренко, М.О. Полянська // Астма і алергія. - 2017. — № 1. - С. 7-12.

24.Фещенко Ю. І. Засади медичної біоетики при наданні пульмонологічної допомоги / Ю. І. Фещенко, Л. О. Яшина, С. Г. Іщук // Астма та алергія. 2012. - № 3 - С. 5-11.

25.Юдина Л.В. Ингаляционные кортикостероиды - основа базисной терапии астмы. В фокусе внимания - моментазона фуморат / Л.В. Юдина // Астма і алергія. - 2016. - № 1. - С. 78-83.

26.Яшина Л.А. Контроль над воспалительным процессом при ХОЗЛ [Текст] // Український пульмонологічний журнал. - 2011. - № 2 - С. 23-24.

27. Adherence to asthma treatments: 'we know, we intend, we advocate / F. Braido, I. Baiardini, F. Blasi, R. Pawankar [et al.] // Curr. Opin. Allergy. Clin. Immunol. - 2014. - V. 15, № 1. - P. 49-55. 
28.Adolescents' inhaled corticosteroid adherence: the importance of treatment perceptions and medication knowledge / E.S. Koster, D. Philbert, N.A. Winters, M.L. Bouvy // J. Asthma. - 2014. - V. 5. - P. 1-6.

29.Advances in asthma in 2016: Designing individualized approaches to management / W.C. Anderson, A.J. Apter, C.M. Dutmer [et al] // J. Allergy Clin. Immunol. - 2017. - № 140. - P. 671-680.

30.Allergen immunotherapy for allergic asthma: a systematic overview of systematic reviews / F. Asamoah, A. Kakourou, S. Dhami // Clin. Transl. Allergy. - 2017. - №7. - P. 25.

31.Asthma Flare-up Diary for Young Children to monitor the severity of exacerbations / F.M. Ducharme, M. E. Jensen, M.J. Mendelson [et al] // J. Allergy Clin. Immunol. - 2016. - Vol. 137. - P. 744-749.

32.Asthma in the elderly and late-onset adult asthma / R.M. Dunn, P.J. Busse, M.E. Wechsler // Allergy. - 2017. - №14. - P. 215-20.

33.Asthma inhaler adherence determinants in adults: systematic review of observational data / A.L. Dima, G. Hernandez, O. Cunillera [et al.] // Eur. Respir J. - 2014. - №4. - P.1233 - 38.

34.Barry MJ. Chronic obstructive pulmonary disease: developing comprehensive management / M.J. Barry // Respir. Care. - 2003. - 48. - P. 1225-34.

35.Bateman E.D. Treatment adherence in asthmatic patients: the last frontier? / E.D.Bateman // J. Allergy Clin. Immunol. - 2014. - V.134. - P. 1269-1270.

36.Di Matteo M.R. Variations in patients' adherence to medical recommendations - a quantitive review of 50 years of research / M.R. Di Matteo // Med Car. 2004. - 42(3). - P. 200-9.

37.Distinguishing characteristics of difficult-to-control asthma in inner-city children and adolescents / J.A. Pongracic, R.Z. Krouse, D.C. Babineau [et al] // J. Allergy Clin. Immunol. - Vol. 138. - P. 1030-1041.

38.EAACI guidelines on allergen immunotherapy: Prevention of allergy / S. Halken , D. Larenas-Linnemann, G. Roberts [et al.] // Pediatr. Allergy Immunol. - 2017. - 123-34.

39.EAACI Guidelines on Allergen Immunotherapy: Hymenoptera venom allergy / G.J. Sturm, E.M. Varga, G. Roberts [et al] // Allergy. - 2017. - №10. - P. 123128.

40.Efficacy of brief motivational interviewing to improve adherence to inhaled corticosteroids among adult asthmatics: results from a randomized controlled pilot feasibility trial / K.L. Lavoie, G. Moullec, C. Lemiere [et al.] // Patient Prefer Adherence. - 2014. - V. 10. - P. 1555-1569.

41.Gaude G.S. Role of health education and self-action plan in improving the drug compliance in bronchial asthma / G.S. Gaude, J. Hattiholi, A.Chaudhury // J. Family Med. Prim. Care. - 2014. - V. 3. - P. 33-38. 
42.Gionfriddo M.R. Why and how to step down chronic asthma drugs / M.R. Gionfriddo, J.B. Hagan, M.A Rank // BMJ. - 2017. - №12. - 359-65.

43.Global Strategy for Asthma Management and Prevention. Revised 2016 [Електронний ресурс]// Режим доступу: www.ginasthma.com

44.Indoor fungal diversity and asthma: A meta-analysis and systematic review of risk factors / R.A. Sharpe, N. Bearman, C.R. Thornton // J. Allergy Clin. Immunol. - 2016. - Vol. 135. - P. 110-122.

45.Inhaler reminders improve adherence with controller treatment in primary care patients withasthma / J.M. Foster, T. Usherwood, L. Smith [et al. ] // J. Allergy Clin Immunol. - 2014. - V. 134, № 6. - P. 1260-1268.

46.Krigsman K. Refill adherence for patients with asthma and COPD: comparison of a pharmacy record database with manually collected repeat prescriptions / Krigsman K, Lars JG, Ring L. // Pharmacoepidemiol Drug Saf. - 2007. - 16. P. 441-8.

47.Lommatzsch M. Severe asthma: definition, diagnosis and treatment / M. Lommatzsch, J.C. Virchow // Dtsch Arztebl Int. - 2014. - № 111 (50). - P. 847-55.

48.Pedersen S. Asthma control in children: Is it important and can we measure it? / S. Pedersen // Paediatr. Respir. Rev. - 2016. - № 17. - P. 36-8.

49. Targeted therapy in severe asthma today: focus on immunoglobulin E / G. Pelaia, G.W. Canonica, A. Matucci // Drug Des. Devel. Ther. - 2017. - № 11. - P. 1979-87. 